\title{
Long-term Effects of a Phragmites australis Invasion on Birds in a Lake Erie Coastal Marsh
}

\author{
by \\ Courtney Dawn Robichaud
}

\author{
A thesis \\ presented to the University of Waterloo \\ in fulfillment of \\ thesis requirements for the degree of \\ Master of Science \\ in \\ Biology
}

Waterloo, Ontario, Canada, 2016

(C) Courtney Dawn Robichaud 2016 


\section{Author's declaration}

I hereby declare that I am the soul author of this thesis. This is a true copy of the thesis, including any required final revisions, as accepted by my examiners.

I understand that my thesis may be made electronically available to the public. 


\section{Abstract}

Invasive Phragmites australis threatens the integrity of essential bird habitat in coastal marshes. Located on the north shore of Lake Erie, Long Point, Ontario provides habitat to thousands of breeding and migrating birds, including marsh-nesting species in decline around the Great Lakes. Invasive $P$. australis has been colonizing these marshes since the late 1990s, when concerns prompted a survey of birds in invaded wetlands (2001-2002). My work evaluates birds in these wetlands after over a decade of $P$. australis expansion, comparing birds among $P$. australis and the vegetation communities it is displacing: cattail marsh, meadow marsh, and open-water marsh. I also examined bird community composition and functional traits to better capture the effects of $P$. australis invasion. I observed substantial changes since the 2001-2002 study was conducted. In 2015, total bird abundance was lower in P. australis than cattail marsh, with little difference in bird species richness among vegetation types. Bird community composition was distinct among all four vegetation types; however, $P$. australis supported a subset of bird species within cattail and meadow marsh habitat, rather than novel bird species. Phragmites habitat excludes many marsh-nesting species and provides habitat for shrub-nesting, foliage gleaner bird species. Marsh-nesters of conservation concern are restricted to remaining cattail and meadow marsh, and open-water habitat. My work indicates that the full effects of $P$. australis invasion may exhibit a lag time, and that community composition and functional traits should be considered when evaluating the effects of a biological invasion. 


\section{Acknowledgements}

This work was supported by funding from NSERC Discovery. I would like to thank my supervisor, Dr. Rebecca Rooney, for her guidance throughout my degree. You have taught me the importance of setting big goals and believing in my results and, maybe most importantly, that everything will go wrong in the field and the best way to handle it is to laugh. I would also like to thank my committee members, Dr. Stephen Murphy and Dr. Kirsten Müller, for their insight and encouragement over the past few years.

To Graham Howell; I could never express how grateful I am that you were willing to wake up at 3:00 am every day, all summer, for this project. I owe you beer, for life. I would also like to acknowledge the support of Danny Bernard (Big Creek National Wildlife Area), Julie Foster (Long Point Provincial Park), Eric Cleland (Crown Marsh), Bird Studies Canada, Ted Barney and Sam Richman (Long Point Waterfowl), and Anne and Scott Hammond that made this project possible. And to my current and former lab mates Daina Anderson, Heather Polan, Adam Kraft, Matt Bolding, Jenny Gleason, Nicole Meyer, and Sarah Yuckin - thank you for your support whether in the lab, the field, or fighting blights.

Finally, I have to thank my family for accepting that I am never home for holidays and supporting me nonetheless. And to my biggest fan, my father. You asked me to finish this quickly so that you could see the final result. That deadline turned out to be unrealistic, but I know you would be proud anyways. 


\section{Table of Contents}

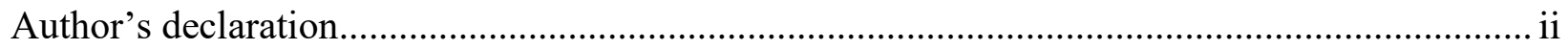

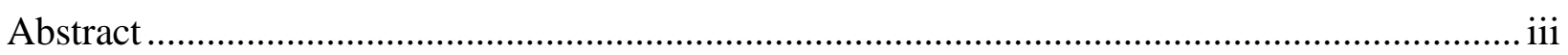

Acknowledgements .......................................................................................................... iv

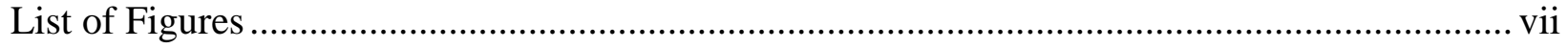

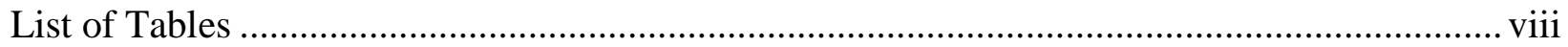

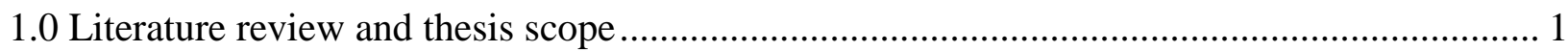

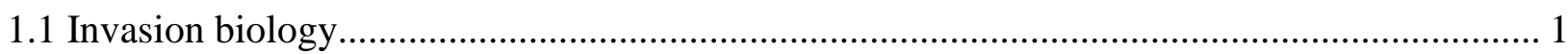

1.2 History of invasion by Phragmites australis …………......................................................... 5

1.3 Phragmites australis biology ....................................................................................... 5

1.3.1 Introduced Phragmites australis .......................................................................... 5

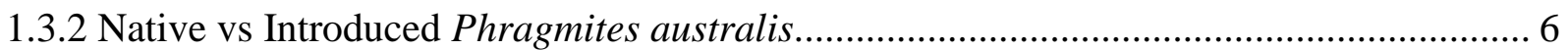

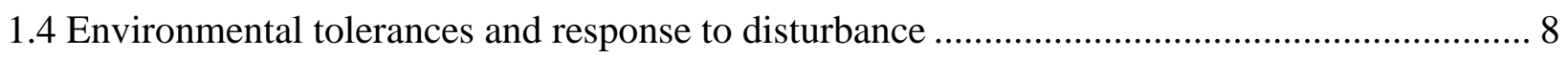

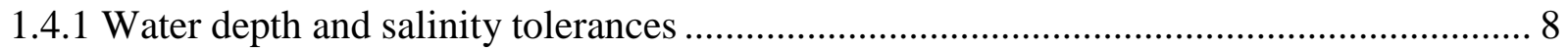

1.4.2 Response to herbivory.............................................................................................. 9

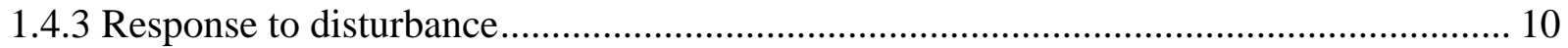

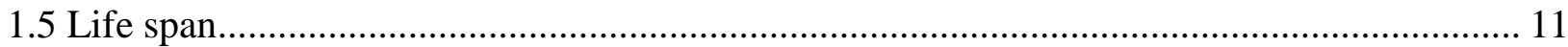

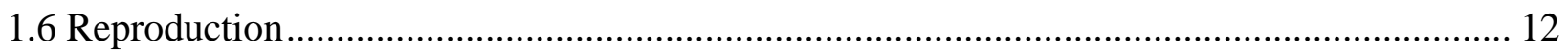

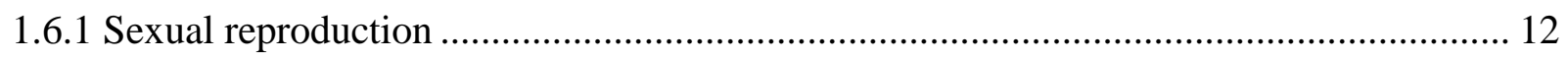

1.6.2 Vegetative reproduction, spread, and patch dynamics................................................ 13

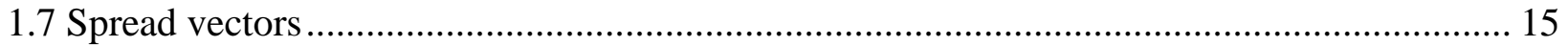

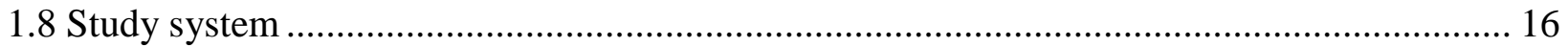

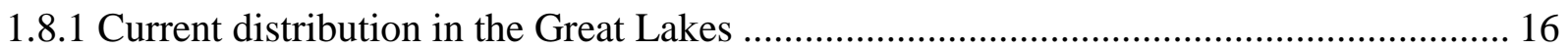

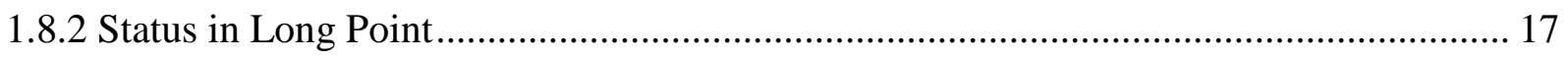

1.8.3 Long Point study area ............................................................................................. 17

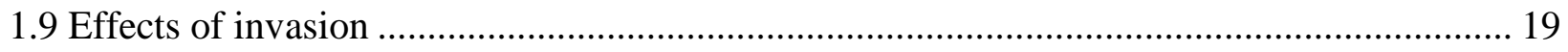

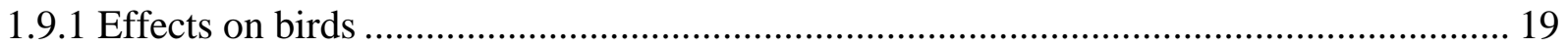

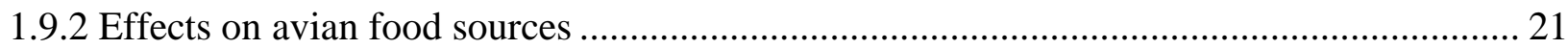

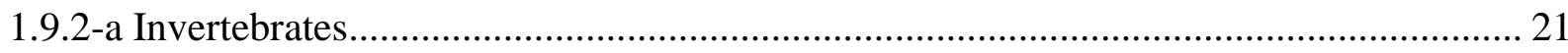

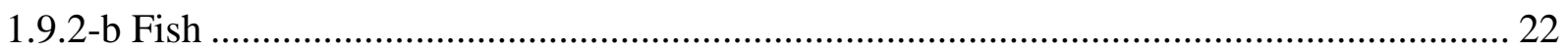

1.9.3 Effects on vegetation communities............................................................................ 23

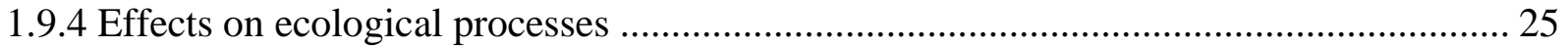




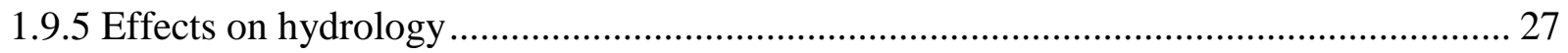

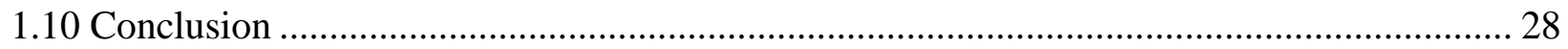

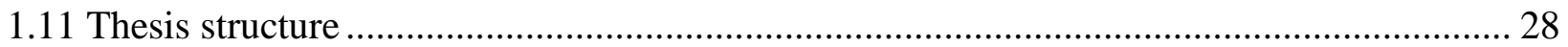

2.0 Effects of Phragmites australis invasion on bird communities in Long Point, ON ............... 32

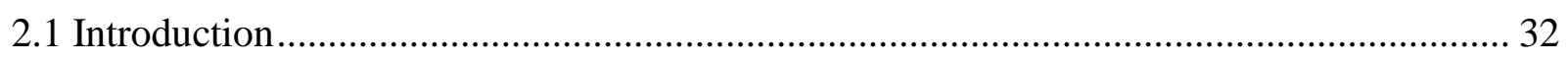

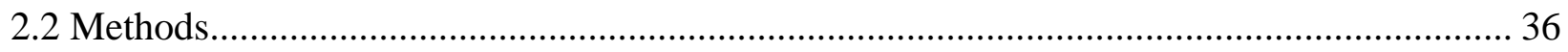

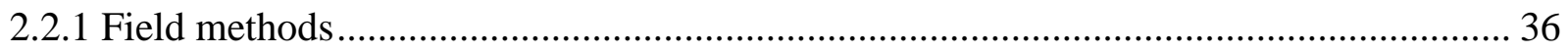

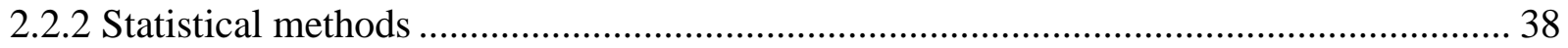

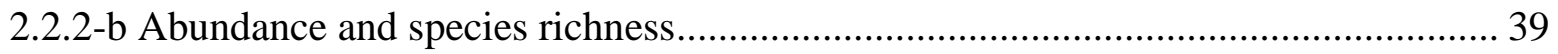

2.2.2-c Community composition and functional traits........................................................... 39

2.2.2-d Vegetation analyses ......................................................................................... 41

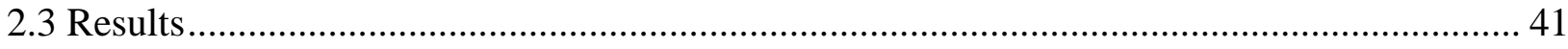

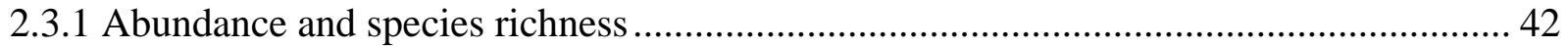

2.3.2 Community composition and functional traits............................................................ 42

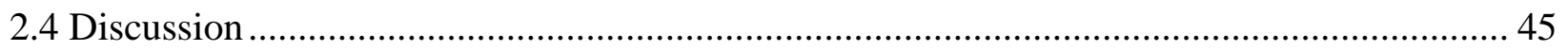

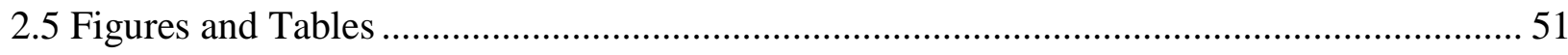

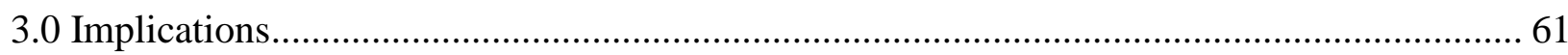

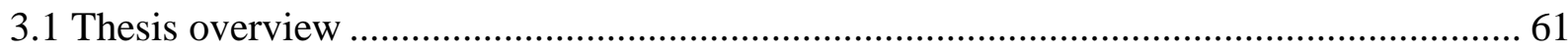

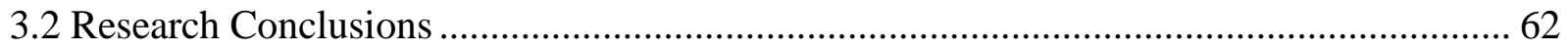

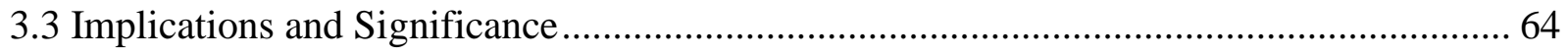

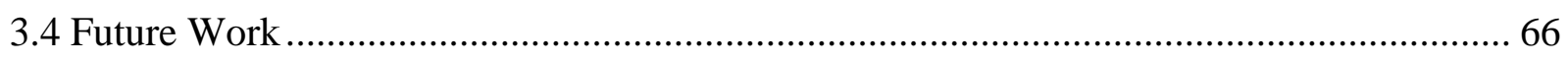

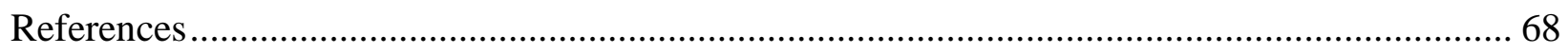

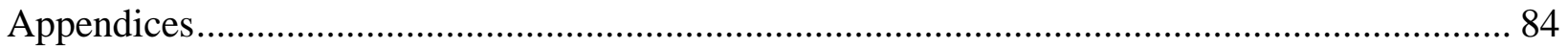

Appendix 1. Photos of the vegetative reproductive characteristics of $P$. australis ................... 84

Appendix 2. Extent of P. australis cover in Long Point, 2015 .............................................. 85

Appendix 3. Photos of point count vegetation types................................... 86

Appendix 4. Summary of plant species observed in each vegetation type .............................. 87

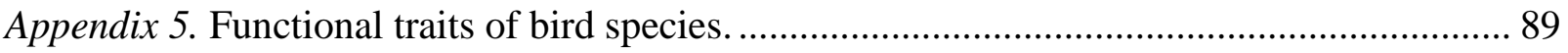

Appendix 6. Sum of all bird sightings by vegetation type …………………………................ 90

Appendix 7. Ordination of bird species excluding open-water................................................... 91

Appendix 8. Point count GPS coordinates and vegetation covariates .........................92 


\section{List of Figures}

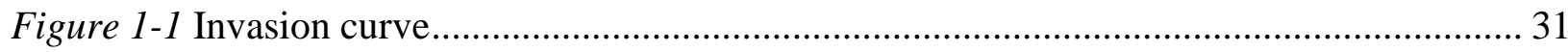

Figure 2-1 Map of bird survey point count locations ....................................................... 51

Figure 2-2. ANOVA results of total bird species richness and abundance ............................... 52

Figure 2-3. ANOVA results of marsh-bird species richness and abundance........................... 53

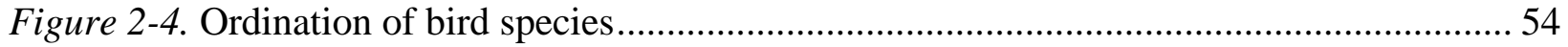

Figure 2-5: Ordination of bird functional traits. ................................................................... 55 


\section{List of Tables}

Table 2-1. Vegetation and environmental characteristics of point count locations .................... 56

Table 2-2. Bird species richness and abundance ANOVA results............................................. 57

Table 2-3. Bird species and functional traits perMANOVA results ....................................... 58

Table 2-4. Bird species and functional traits MRPP results. .................................................. 59

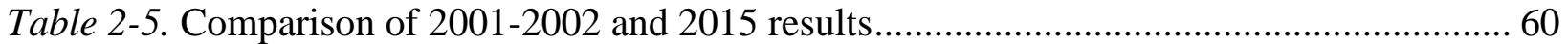




\subsection{Literature review and thesis scope}

The introduced aquatic grass Phragmites australis (Cav.) Trin. ex Steud (European common reed; P. australis hereafter) is rapidly spreading throughout North American wetlands. The tall, dense stands created by this aggressive invader alter wetlands by reducing light availability, filling in areas of open-water, negatively impacting floral diversity, and increasing litter accretion rates (Able et al., 2003; Hirtreiter and Potts, 2012; Keller, 2000; Rooth et al., 2003). Phragmites australis invasion is changing the coastal marshes of Long Point, ON, where more than $70 \%$ of the total wetland area on the north shore of Lake Erie is found (Ball et al., 2003). In addition to being a critical staging ground for both the Mississippi and Atlantic Flyways, Long Point provides essential habitat to a number of bird species that rely on marshes for breeding (Bird Studies Canada, 2016). The expansion of $P$. australis in Long Point in the late 1990s led to the displacement of historical resident meadow marsh and cattail marsh (Wilcox et al., 2003), changing these coastal habitats with potential consequences for the birds that rely on them. In my thesis, I evaluate the effect of the $P$. australis invasion in Long Point on bird communities. This literature provides background information in support of that aim, namely I review the history of P. australis invasion in Canada and evaluate the state of our knowledge of $P$. australis biology and its effects on invaded ecosystems, with special reference to potential direct and indirect effects on waterbirds.

\subsection{Invasion biology}

The introduction of a non-native species into a new environment can have far-reaching consequences for the resident species, biological communities, and ecological functions of an invaded system (Cadotte et al., 2006; Vilà et al., 2011). Introduced plants have been shown to 
have bottom-up effects on higher trophic levels, and reduce resident plant species diversity (Vilà et al., 2011). In the United States, introduced species pose a significant risk to threatened or endangered species and have been estimated to cost the country $\$ 120$ billion a year in environmental damages and losses (Pimentel et al., 2005). In Canada, of the 488 species categorized as at risk in 2006, 22\% were considered most severely threatened by introduced species (Venter et al. 2006). While the consequences of introduced species are serious, many non-native species introduced to new ecosystems fail to overcome the many abiotic and biotic barriers to become invasive (Mack et al., 2000). Biological invasions, for conceptual clarity, are commonly described as occurring in a series of non-discrete stages: transport/introduction, colonization, establishment, and spread (Fig. 1-1) (Davis, 2009; Theoharides and Dukes, 2007; Vermeij, 1996). A species that can form reproducing populations in a new range is considered introduced, or naturalized, but only once this species spreads outside of its introduced range is it considered invasive (Richardson et al. 2000b).

The first stage of invasion, transport, involves movement over a geographic barrier, usually facilitated by human activities. For a species to successfully reach a new range there must be multiple opportunities for propagules to survive transport and reach a new environment, otherwise known as high propagule pressure (Lockwood et al., 2005; Richardson et al., 2000a,b). Propagule pressure is a measurement of the number of individuals released into new area, and includes a measure of both the number of individuals released in any one event and the number of release events (Lockwood et al., 2005). During the transport stage, the more abundant the propagules reaching the new area, the greater the likelihood of successful transport (Theoharides and Dukes, 2007). Furthermore, species with a large native range that experience multiple 
successful introductions may exhibit higher genetic diversity in their new range, helping the species escape genetic bottlenecks in their introduced range (Theoharides and Dukes, 2007).

The second stage is colonization. For a plant to successfully colonize a new environment - survive the transport stage and begin to grow in the new area - there are a number of abiotic factors to overcome. While climate is a coarse filter for many introduced species, the availability of light, nutrients, and moisture can also determine if an introduced species will be successful (Theoharides and Dukes, 2007). Disturbance that removes resident vegetation and adds nutrients can increase the probability of transport leading to successful colonization (Leishman and Thomson, 2005; Minchinton and Bertness, 2003). High propagule pressure is also a factor in colonization success, as this can rescue small introduced populations from extinction by providing a constant addition of viable propagules to the area (Theoharides and Dukes, 2007). If the introduced species has colonized a site and is able to reproduce, creating a self-sustaining population without any anthropogenic assistance, the invasion progresses to the third stage: establishment (Theoharides and Dukes, 2007).

Establishment requires that the introduced plant species to be able to tolerate the abiotic factors of the new range, and overcome limitations from biotic interactions (Theoharides and Dukes, 2007). During this stage, a species must be able to access resources that are adequate for growth, maintenance and reproduction, find gametes for out-crossing, and survive long enough to reproduce (Davis, 2009). If the population is self-sustaining in its introduce range it can be considered "naturalized" (Richardson et al., 2000b). In this stage, invasive species benefit from traits that enhance competitive performance (fast growth, allelopathy) and reduce niche overlap with resident plants (Theoharides and Dukes, 2007). Interactions other than competition also contribute to the success of introduced species. The enemy-escape hypothesis, i.e., the transport 
of the introduced species outside of its enemies' range, (e.g. Wolfe, 2002), has been suggested to benefit introduced species in their new range. With less herbivore or predator pressure, introduced species may allocate more energy to growth rather than defenses (Blossey and Notzold, 1995). In direct regards to reproduction, species that can reproduce vegetatively or do not rely on pollinators may have an advantage during establishment (Richardson et al., 2000a; Theoharides and Dukes, 2007).

To be considered "invasive" a species must persist and expand its distribution outside of its introduced range. This leads to the next stage of invasion, "spread", which can involve both a gradual increase in spatial cover and new populations arising from dispersal from the original colonization sites (Davis, 2009; Theoharides and Dukes, 2007). Human activities are central to the spread stage. Habitat fragmentation by humans can facilitate the spread stage of invasion, resulting in high concentrations of introduced species along habitat edges (Theoharides and Dukes, 2007). Disturbances, such as transportation routes, that result in more edge habitat, pathways connecting different habitat, and the removal of resident plant communities and addition of nutrients provide ample opportunity to invasive species to spread.

While many species are introduced into new ranges, few are able to overcome the limitations of new environments. Those that do, and are capable of creating reproducing populations that spread outside of their introduced range, can have a number of effects on resident ecosystems, changing community interactions, altering habitats, and affecting biodiversity. The stages of invasion provide a conceptual model for framing the spatial and temporal differences in invasion progression (Fig. 1-1). Likely, when examining the effects of a biological invasion on a certain community, there will be differences in the community's response over these various stages. 


\subsection{History of invasion by Phragmites australis}

The first record of introduced P. australis in Canada is from 1910 in Nova Scotia, and by the 1920s it had reached the St. Lawrence River, near Quebec City (Catling and Mitrow, 2011). By 1950, it was observed only in four areas within Canada, compared to the native lineage's widespread distribution (Catling and Mitrow, 2011). Within Quebec, the introduced lineage was rare until the 1970s, when it began to spread inland facilitated by the development of transportation networks (Lelong et al., 2007). By 1990, introduced P. australis had spread throughout the St. Lawrence and Southern Ontario (Catling and Mitrow, 2011) and became a dominant wetland species in many marshes (Lelong et al., 2007). Introduced P. australis is now spreading further west, into northern Ontario, southern Manitoba, and southern British Columbia, and is expected to become established across most of southern Canada (Catling and Mitrow, 2011).

\subsection{Phragmites australis biology}

\subsubsection{Introduced Phragmites australis}

The genus Phragmites currently includes four species: Phragmites australis (Cav.) Trin. Ex Steud, Phragmites japonicas Steud., Phragmites karka (Retz.) Trin. Ex Steud., and Phragmites mauritianus Kunth (Saltonstall, 2016; WCSP, 2015), of which only Phragmites australis has a global distribution (Saltonstall, 2016). The taxonomy of $P$. australis is out of date, though there has been extensive research into the species in North America. What does remain clear is there are three lineages of $P$. australis in North America: a native lineage, previously designated as $P$. australis ssp. americanus (Saltonstall, P.M. Peterson, \& Soreng), a Gulf Coast lineage, $P$.

australis var. berlandieri (E. Fourn.) Saltonstall \& Hauber, and an introduced lineage. The 
introduced lineage is differentiated based on morphological characteristics and chloroplast DNA markers. Evidence suggests that the introduced lineage is quite diverse relative to the native lineage (Plut et al., 2011). Haplotype M is the most widespread haplotype from the introduced lineage, and most likely originates in the UK (Plut et al., 2011). The high genetic diversity in the introduced lineage is interpreted as evidence of multiple introduction events and a high propagule pressure from the genetically diverse European range of $P$. australis (Plut et al., 2011). This is supported by the recent discovery of a second haplotype of introduced P. australis, haplotype L1, in Quebec (Meyerson and Cronin, 2013). In addition, some of the genetic variation observed in the introduced $P$. australis is due to transmission of chloroplast DNA through pollen (paternal leakage), resulting in novel haplotypes that experts believe arose in North America (Lambertini, 2016). As a consequence of these recent discoveries, the taxonomy of $P$. australis is in flux. Currently, the introduced and native lineages of $P$. australis are treated as different subspecies by certain authors (e.g. Bhattarai et al. 2016; Saltonstall et al. 2016) although the integrated taxonomic information system considers $P$. australis ssp. americanus and ssp. australis to be synonymous. For clarity in this document, any reference to $P$. australis will mean the introduced lineage, unless otherwise specified.

\subsubsection{Native vs Introduced Phragmites australis}

Gene flow between introduced $P$. australis and native $P$. australis is low, even where there is geographical overlap between multiple lineages (Saltonstall, 2003b; Saltonstall et al., 2010), though instances of hybridization have recently been observed (Meyerson et al., 2012; Saltonstall et al., 2016, 2014). Introduced $P$. australis exhibits more aggressive growth and establishment characteristics than its native counterpart. Introduced $P$. australis shoots emerge earlier in the 
growing season, produce double the total and leaf biomass, and transition faster from buds to root or shoot tissues (League et al., 2006). Compared with the native lineage, introduced $P$. australis has a $38-83 \%$ larger photosynthetic canopy, higher specific leaf area, and maintains a $51 \%$ greater photosynthetic rate (Mozdzer and Zieman, 2010). Patches of introduced $P$. australis are also denser and taller than the native lineage. A comparison between native $P$. australis and introduced $P$. australis in coastal and inland wetlands near Lake Michigan found that introduced P. australis exhibited greater stem densities (31.9 stems per $\left.\mathrm{m}^{2}\right)$ than the native lineage $(22.3$ stems per $\mathrm{m}^{2}$ ), and reached a higher maximum height $(306 \mathrm{~cm})$ than the native lineage $(246 \mathrm{~cm})$ (Price et al., 2014). While the native lineage does produces patches that can be quite tall and dense, the diversity and species composition of vegetation communities associated with native $P$. australis were similar to uninvaded communities, while vegetation associated with introduced $P$. australis had low diversity and supported more generalist species (Price et al., 2014). This suggests that the height and density characteristics alone of $P$. australis cannot fully account for its success as an invader.

The differences in lineages are also manifested in rhizome structure. The rhizomes of introduced $P$. australis are larger than native rhizomes. The diameters of native rhizomes are less than $15 \mathrm{~mm}$, while introduced rhizomes are flatter and greater than $15 \mathrm{~mm}$ in diameter (Mal and Narine, 2004). Introduced $P$. australis allocates $60-70 \%$ of its total biomass to roots and rhizomes (Mal and Narine, 2004; Shay and Shay, 1986), creating extensive networks that capture soil nutrients. Rhizomes can mobilize resources and allocate them to younger, smaller shoots during the early growing stage to achieve a more uniform final stand structure (Hara et al., 1993). This clonal subsidy provides a boost to P. australis and enhances the growth of young, uneven aged stands (Hara et al., 1993). These above- and below-ground structures maximize 
resource consumption for $P$. australis, improving competitive ability, but they are not the only factor that allows the introduced lineage to be so prolific. The introduced lineage is also more responsive to disturbances and increases in nutrient availability, an attribute which has been linked to its successful invasion of disturbed wetlands where nutrient pollution is a common result of human activities (Minchinton and Bertness, 2003).

\subsection{Environmental tolerances and response to disturbance}

\subsubsection{Water depth and salinity tolerances}

In addition to aggressive growth characteristics, introduced $P$. australis can tolerate a broad range of environmental conditions and hazards. Introduced $P$. australis can grow in a wide range of water depths, from areas where the water table is a meter below the soil surface to standing water greater than $50 \mathrm{~cm}$ deep (Shay and Shay, 1986). Experiments growing P. australis in variable water depths, reaching up to $230 \mathrm{~cm}$, have revealed developmental plasticity in $P$. australis which allows it to adapt its morphology to different water depths (Engloner and Papp, 2006; Vretare et al., 2001). In deep water, $70-75 \mathrm{~cm}, P$. australis allocates less biomass belowground and makes fewer, taller shoots which serve to increase gas exchange but can make the plant more vulnerable to wave action (Vretare et al., 2001). This may be the reason that introduced $P$. australis in natural settings seems limited to water depths less than $100 \mathrm{~cm}$ and its growth is restricted under prolonged flooding (> 100 days) (Hudon et al., 2005; Shay and Shay, 1986).

Introduced $P$. australis is also tolerant to a range of salinities and able to grow in freshwater, brackish, and salt marshes (Konisky and Burdick, 2004). Introduced P. australis has higher relative growth rates and is capable of producing more shoots in saline and freshwater 
environments than the native lineage, and can maintain half of its growth potential at $0.4 \mathrm{M}$ $\mathrm{NaCl}$, while native lineages cannot grow above $0.1 \mathrm{M} \mathrm{NaCl}$ (Vasquez et al., 2005). The ability of introduced $P$. australis to survive fluctuating water levels and salinity levels may explain why it is so often observed in road side ditches, where de-icing salt is often applied (Jodoin et al., 2008). Certainly, the capacity to tolerate a wide range of environmental conditions would facilitate invasion into new habitats.

\subsubsection{Response to herbivory}

The predator escape hypothesis is commonly called upon to explain the success of an invading species (e.g., Wolfe, 2002), and in the case of introduced P. australis it seems plausible that reduced grazing and infection may contribute to the success of the introduced lineages. Introduced $P$. australis also appears to have a higher resistance to pests and herbivores than the native lineage. Aphid (Aphididae) densities were significantly lower on non-native plants, while native $P$. australis was extensively fed on or even killed (Lambert and Casagrande, 2007). Lambert et al. 2007 focused on gall flies (Lipara sp.) in P. australis and found that, when stands were adjacent to each other, introduced $P$. australis was colonized less than native plants, which did not flower when they were infected (Lambert et al., 2007). In other field and common greenhouse comparisons, native $P$. australis experienced significantly higher aphid densities and gallfly damage to leaves and stems than introduced P. australis (Park and Blossey, 2008).

The co-evolutionary history of introduced $P$. australis has also been suggested as a reason it may experience less herbivory pressure in North America. Native P. australis has coevolved with fewer than 10 herbivore species, while in Europe introduced $P$. australis evolved with over 100 herbivores (Tewksbury et al., 2002). In North America, the current assemblage of 
herbivores feeding on both introduced and native $P$. australis is mostly comprised of introduced European species, leading researchers to hypothesize that introduced $P$. australis experiences lower predation because of its co-evolutionary history (Park and Blossey, 2008; Tewksbury et al., 2002). However, there is on-going debate in the literature about whether herbivores really are haplotype-specific and the implications for biological control of $P$. australis. Some argue that certain species of insects are specific in consuming the introduced haplotype, and pose minimal threats to native plant species (Blossey and Casagrande, 2016a, 2016b), while others believe that the predation is not specific enough and it poses a risk to non-target plants (Bhattarai et al., 2016). Hence, the potential of biocontrol agents to assist in P. australis control remains hotly contested and requires additional study.

\subsubsection{Response to disturbance}

Anthropogenic and natural disturbances create canopy gaps or empty niches that represent opportunities for $P$. australis invasion, as the introduced lineage is opportunistic and tolerant of disturbance. Once a gap is created, its rapid growth rate and ability to reproduce vegetatively (see below) help P. australis become established (Zedler and Kercher, 2004). Phragmites australis density is positively associated with the percent of surrounding developed land (Hughes et al., 2016), and in newly invaded areas the introduced lineage was found most frequently in areas with urban disturbance near wetlands (Lambert et al., 2016). In Chesapeake Bay, the prevalence of agriculture was a strong predictor of $P$. australis invasion at regional and local scales (Sciance et al., 2016). Experimental manipulation mimicking shoreline disturbance via vegetation removal and nutrient addition increased the cover, density, and height of introduced $P$. australis, as well as the distance shoots spread laterally (Minchinton and Bertness, 
2003). Introduced $P$. australis excels at proliferating in disturbed areas, capitalizing on the exposed substrate and nutrient additions typically associated with urban and agricultural development.

In addition to anthropogenic disturbances, natural disturbances such as storms allow $P$. australis to proliferate. For example, the high rates of precipitation during an El Niño year led to P. australis producing $30 \%$ more shoots, which were $25 \%$ taller and had significantly more inflorescences than the year before in coastal brackish marshes of southern New England (Minchinton, 2002). Similarly, the natural drawdown of Lake Erie in the 1990s is thought to be responsible for the rapid expansion of introduced P. australis, as reported by Wilcox (2012). Thus, $P$. australis benefits from its wide tolerance environmental conditions and its ability to take advantage of nutrient pollution and physical disturbance through rapid growth and canopy closure.

\subsection{Life span}

Although the ramets or above ground portions of $P$. australis plants senesce every fall, the rhizomes of $P$. australis are perennial and because of its clonal growth form, individuals may live a long time. There is not an abundance of data on $P$. australis life span, but some research suggests that a single clone of $P$. australis can maintain itself for hundreds of years (Haslam, 1972). Phragmites australis can reproduce both vegetatively, via rhizomes or stolons, and sexually, via seeds. The rhizomes of $P$. australis live approximately 3-7 years (Mal and Narine, 2004), and buds emerge in April or May, reach their final height in late August, and flower $4-5$ months after emergence (Haslam, 1970a). Introduced P. australis has an extended growing season relative to the native lineage, and does not begin senescing until September or October 
(Mozdzer and Zieman, 2010). The length of the growing season may provide introduced $P$. australis with more opportunity for nutrient uptake and carbohydrate synthesis, contributing to its success as an invader (Zedler and Kercher, 2004).

\subsection{Reproduction}

\subsubsection{Sexual reproduction}

Phragmites australis is able to reproduce both sexually and asexually which allows it to spread widely, colonize new areas, and maintain high genetic diversity while also establishing stands of locally adapted clones, well suited to surrounding environmental conditions (Kettenring et al., 2016). Sexual reproduction in $P$. australis is not considered its primary reproductive strategy, but there is mounting evidence that reproduction via seeds is essential for colonizing new areas (Belzile et al., 2010; Kettenring et al., 2016; Kettenring and Mock, 2012). Seed dispersal and sexual reproduction appears to be more common in the introduced lineage than the native and potentially offer more opportunities for seedling establishment (Kettenring and Mock, 2012). In populations of $P$. australis that have been examined for genetic relatedness, there is usually a great deal of genetic diversity that is indicative of seeds as a primary reproductive propagule (Belzile et al., 2010; Stabile et al., 2016). The seeds of $P$. australis mature at the end of its growing season, from September to October, and it can take years after sprouting for flowering shoots to emerge (Ishii and Kadono, 2002; Saltonstall et al., 2010).

Phragmites australis is also capable of self-fertilization, and the large flowers of the introduced lineage, larger than native $P$. australis, produce a great amount of highly fertile, wind-dispersed pollen (Lambert and Casagrande, 2007; Saltonstall et al., 2010). The ability to self-pollinate provides an advantage during the colonization stage of invasion, allowing $P$. 
australis to bypass biotic limitations in new environments (Richardson et al., 2000a; Theoharides and Dukes, 2007). Self-pollination may also give $P$. australis the opportunity to move into regions with poor pollen availability, and to expand further in areas where the plant is already established (Lambert and Casagrande, 2007).

The longevity of seeds in North American wetlands is not well understood (Baldwin et al., 2010), but field observations suggest seeds may persist for over a decade. As evidence of longevity, the expansion of $P$. australis in the Great Lakes region in the 1990s is attributed to $P$. australis inoculating the seedbank during previous low water levels of the 1980s (Wilcox, 2012). Germination and establishment of $P$. australis is closely tied to water levels. For establishment, seeds require wet soil that is not flooded above $1 \mathrm{~cm}$, contains high nutrients, and has an open canopy (Haslam, 1971a). Early germination and establishment is important for P. australis seedling survival, as it allows shoots time to emerge above water and reach the light (Weisner and Ekstam, 1993). Long term inundation of seedlings will result in decreased survival, and this effect is enhanced by the presence of algae that can further hamper photosynthesis (Armstrong et al., 1999). While flooding can kill seedlings, they are also susceptible to drying if too exposed and to competition with established plants (Haslam, 1972).

\subsubsection{Vegetative reproduction, spread, and patch dynamics}

Phragmites australis patches can become established by either seeds or vegetative propagules, but their aggressive lateral spread is facilitated by rhizomes and above-ground stems (Mal and Narine, 2004). Phragmites australis can spread by colonization, linear clonal growth, or circular clonal growth of patches, and within invaded wetlands patch numbers increase over time before decreasing as large patches integrate with one another (Lathrop et al., 2003). Lateral 
expansion of patches is enhanced by stolons, which can arise from fallen stems or horizontal rhizomes (Appendix 1c) (Brisson et al., 2010). Phragmites australis relies heavily on these means of vegetative reproduction. Rhizomes in particular are capable of growing $2 \mathrm{~m}$ in one year and are an effective way to expand the population size as fragments as small as $10-20 \mathrm{~cm}$ can produce a new plant (Appendix 1a,b) (Juneau and Tarasoff, 2013). The rhizomes of P. australis are resilient to a number of stressors and are able to withstand temperature lows of $-20{ }^{\circ} \mathrm{C}$, fire, disease, predators, and water stress (Mal and Narine, 2004), allowing them to disperse large distances. Vegetative growth also allows $P$. australis to expand into areas with deeper water than seeds could germinate in (Amsberry et al., 2000).

The structure of $P$. australis below-ground tissues consists of a main vertical rhizome growing from a horizontal rhizome that terminates in a shoot (Appendix 1b) (Haslam, 1970b). These horizontal rhizomes are responsible for renewing and maintaining the population without them the vertical rhizomes become reduced in size until they die (Haslam, 1969). In the fall, $P$. australis resources are translocated from above-ground tissue into rhizomes, and are allocated to new growth in the spring (Juneau and Tarasoff, 2013). The primary storage carbohydrate is starch (Mal and Narine, 2004), which comprises $1-10 \%$ of above-ground biomass and $5-20 \%$ is stored in below-ground biomass (Wersal et al., 2013). Rhizomes that undergo overwintering receive carbohydrates from shoots to encourage growth when the growing season returns (Boar, 1996; Wersal et al., 2013), and it follows that rhizomes collected for greenhouse experiments in the fall have higher survivorship than those collected in the spring (Juneau and Tarasoff, 2013). Rhizomes allow P. australis to allocate resources to young shoots to achieve a stand structure with more uniform shoot height and weight (Hara et al., 1993). This clonal subsidy provides a boost to shoots that may be growing in less optimal conditions. 


\subsection{Spread vectors}

The introduction of $P$. australis into North American in the 1990s most likely occurred at shipping ports where P. australis was transported from Europe in ship ballasts, and potentially used to fill in marshes that were later converted to railways or shipping ports (Lavoie et al., 2003; Saltonstall, 2002). A number of pathways have facilitated $P$. australis spread throughout North America, but the most predominant are transportation routes, including roads, railways, or shipping routes which create pathways between habitat ideal for colonization (Brisson et al., 2010). Phragmites australis was found around the St. Lawrence River in the 1960s and 70s, and the construction of transportation routes and agricultural drainage in this area provided ample opportunities for spread (Kettenring et al., 2012).

Roadways are a major contributor to $P$. australis spread as they create a network between suitable habitat, and $P$. australis can withstand increased salinity from sources such as de-icing salt while less salt tolerant species may be excluded (Brisson et al., 2010; Jodoin et al., 2008; Maheu-Giroux and de Blois, 2007; Zedler and Kercher, 2004). Heavy machinery, such as construction equipment, can transport rhizome fragments along roadways (Saltonstall et al., 2010), and invasion is common in disturbed habitat near roads. Introduced $P$. australis is abundant within wetlands that border roadways (Jodoin et al., 2008) and man-made wetlands near roads are more likely to be invaded than riparian habitats further from roads (Maheu-Giroux and de Blois, 2005). Seasonal flooding events may move rhizome propagules to new areas, and some research suggests that long distance dispersal occurs via waterways while short distance dispersal is over land (Kirk et al., 2011; Lavoie et al., 2003; Saltonstall et al., 2010). Genetic relatedness between stands declines with increasing distance, but $P$. australis appears to be able to disperse up to $500 \mathrm{~m}$ from an area (McCormick et al., 2016). 


\subsection{Study system}

\subsubsection{Current distribution in the Great Lakes}

Water level fluctuation can change vegetation composition and assist invasions, as exemplified among Great Lakes coastal wetlands (Wilcox, 2012). Emergent vegetation cover increases during low water levels, a trend observed in both Lake Erie and Lake Michigan where $P$. australis cover expanded after a water level drop (Tulbure et al., 2007; Whyte et al., 2008). In the late 1980s introduced P. australis was not a dominant plant species in the Great Lakes - at this time Typha was the dominant plant species and the main concern towards Great Lake biodiversity (Keddy and Reznicek, 1986).

Tulbure and Johnston (2010) assessed the distribution of P. australis throughout the Great Lakes and noted that $P$. australis invasion was greater in Lakes Michigan, Huron and Erie, all of which experienced water level decreases between 1999 and 2001, while Lake Ontario, which experienced higher water levels between 1999 and 2001, had less P. australis. A 2007 study of Great Lakes coastal wetlands revealed that exotic plants were more prevalent in wetlands in Lake Erie and Ontario, intermediate in Lake Michigan, and lowest in Lakes Superior and Huron, but $P$. australis was present in all of the Great Lakes and was typically the dominant plant species (Trebitz and Taylor 2007). The presence of P. australis in the lower Great Lakes seems to be related to the amount of agriculture in the surrounding landscape, though the relationship may also be driven by other anthropogenic disturbances such as pollution (Trebitz and Taylor 2007). 


\subsubsection{Status in Long Point}

Phragmites australis is identifiable in aerial photos of Long Point dating back to 1945 in small amounts (4 ha to 17 ha), but it expanded from 18 ha to 137 ha between 1995 and 1999 (Wilcox et al., 2003). The low water levels in Lake Erie during the mid-1980s likely provided a chance for $P$. australis to inoculate exposed soil, and to emerge during the next low (Tulbure and Johnston, 2010; Whyte et al., 2008; Wilcox et al., 2003). Of the P. australis population in Long Point examined by Wilcox et al. (2003), 90\% of the stands were haplotype M, and P. australis mostly displaced resident Typha spp. (34\%) and marsh meadow (31\%) in the expansion between 1995 and 1999. More current mapping initiatives are underway in Long Point (Appendix 2), but little has been done since 2002 in terms of $P$. australis management and research from McMaster indicates that $P$. australis is still rapidly expanding throughout Long Point (Marcaccio and Chow-Fraser, 2016).

\subsubsection{Long Point study area}

Located in the Carolinian zone of southern Ontario, Long Point is a $35 \mathrm{~km}$ sandspit that extends into Lake Erie, containing 13,465 ha of wetlands and accounting for $70 \%$ of the total wetland area on the north shore of Lake Erie (Ball et al., 2003). The spit contains a number of ecologically significant zones and surrounds the Long Point inner bay, a $78 \mathrm{~km}^{2}$ body of water partially separated and protected from the wave action of Lake Erie (Meyer, 2003; UNESCO, 2015). On the Long Point sandspit, the undulating ridges create distinct plant communities ranging from dunes on the southern beach, to wet sedge meadow, to Cottonwood savanna (Reznicek and Catling, 1989). The differences in elevation along the sandspit also contribute to a mosaic of habitats with ponds, meadows, and marshes occurring throughout Long Point 
(Reznicek and Catling, 1989). Many of these vegetation zones are important for maintaining plant diversity and abundance as Long Point supports rare coastal marsh meadow habitat and a number of provincially rare plant species, many of which are wetland or aquatic species (Ball et al., 2003; Prince et al., 1992; Reznicek and Catling, 1989).

In addition to supporting diverse and significant vegetation communities, Long Point is an important area for avifauna. Located on the Atlantic flyway, the abundant submerged aquatic vegetation and protected waters of the bay and marsh complexes make Long Point a waterfowl staging area of international importance (Knapton and Petrie, 1999; Prince et al., 1992). Many migratory song birds also use Long Point as a stop-over, and several provincially significant bird species such as Bald Eagle (Haliaeetus leucocephalus), Least Bittern (Ixobrychus exilis), Great Egret (Ardea alba), and Black Tern (Chlidonias niger) nest and feed in or near the coastal marshes (Ball et al., 2003). The regional and international importance of Long Point has been recognized through designations as a UNESCO World Biosphere Reserve, a RAMSAR wetland of international significance, and an Important Bird Area.

The significance of Long Point is evident when the context of the surrounding landscape is considered. Southern Ontario has experienced a substantial loss of wetlands since presettlement time: $72 \%$ in total, and an estimated loss of 3.5\% per year since 1982, equivalent to 3,543 ha per year (Ducks Unlimited Canada, 2010). Haldimand-Norfolk, the county Long Point is in, has lost $65-85 \%$ of its wetland area since pre-settlement time (Ducks Unlimited Canada, 2010). This significant loss of wetland habitat in Haldimand-Norfolk emphasizes the ecological importance of Long Point for marsh dependent species in the region. 


\subsection{Effects of invasion}

\subsubsection{Effects on birds}

My thesis is primarily concerned with the effects of $P$. australis invasion on birds, and so I will begin this section with a review of the conflicting evidence on how sensitive bird communities are to $P$. australis invasion. The changes that occur in wetlands when $P$. australis invades can affect birds that use these habitats directly and indirectly, though there is no consensus on what these effects are.

Early work in salt and brackish marshes found a decrease in bird species richness in $P$. australis habitat compared with short grass meadow and brackish mixture (emergent and short graminoid mix) (Benoit and Askins, 1999). Additionally, the bird species found within $P$. australis were present across all marsh habitat while state-listed species were confined to either short grass meadow, brackish mixture, or both (Benoit and Askins, 1999). Short-grass meadows were dominated by salt marsh specialists and generalists, while Marsh Wren (Cistothorus palustris), Red-winged Blackbird (Agelaius phoeniceus), and Swamp Sparrow (Melospiza georgiana) were most abundant in P. australis (Benoit and Askins, 1999). More recent work in tidal marshes along the Hudson Bay Estuary also found that $P$. australis invasion decreased bird species richness, changing the marshes from a diverse bird community to one dominated by Redwinged Blackbirds (Wells et al., 2008). In Lake Erie coastal marshes located in Ohio, $P$. australis patches supported the highest bird abundance but lowest species diversity when compared with floating-leaved, cattail, and mixed emergent habitat, but the observed increase in bird abundance was attributed to large roosts of Red-winged Blackbird using P. australis (Whyte et al., 2015). Tall, large patches of $P$. australis are considered low quality breeding habitat because of their closed canopy and dense stems, and increases in P. australis cover are predicted 
to decrease available roosting area for large-bodied birds such as Sandhill Crane (Grus

canadensis) (Kessler et al., 2011); however, this decrease in roosting habitat may be offset by an increase in preferred hunting habitat as there is some evidence that larger-bodied birds use the edges of stands as feeding grounds (Benoit and Askins, 1999).

In contrast to the evidence that bird diversity is negatively affected by $P$. australis invasion, at least in the interior of $P$. australis stands, two studies from Long Point, ON suggest that $P$. australis may actually be beneficial to birds. In 2001-2002, a study comparing bird abundance and diversity between $P$. australis, cattail, and meadow marsh habitat found that $P$. australis supported a significantly higher total bird abundance and species richness, with these effects most strongly exhibited along the edge of $P$. australis habitat (Meyer et al., 2010). The bird communities within $P$. australis had higher abundances of Common Yellowthroat (Geothlypis trichas), Swamp Sparrow, Eastern Kingbird (Tyrannus tyrannus), Willow Flycatcher (Empidonax traillii), and Yellow Warbler (Dendroica petechia) (Meyer et al., 2010). There were no differences between the invaded and uninvaded marsh types in terms of marsh-nesting bird richness, though $25 \%$ more marsh-nesting individuals were observed in meadow marsh than $P$. australis (Meyer et al., 2010). In another Long Point study, researchers compared bird abundance and richness within natural ponds, dredged ponds, and mixed cattail- P. australis emergent vegetation and found that ponds supported greater total species richness and marshnesting species richness than cattail- P. australis habitat (Schummer et al., 2012). These researchers agreed with Meyer et al. (2010), and concluded that dredging ponds led to an increase in bird richness and abundance due to the creation of more edge habitat (Schummer et al., 2012). 
A study by Gagnon Lupien et al. (2015) examining the effects of $P$. australis invasion on birds concluded that invasion had minimal effects. In recently invaded marshes in Quebec, $P$. australis did not appear to have any substantial effect on the richness, abundance, or diversity of songbirds or waterbirds using the marsh (Gagnon Lupien et al., 2015). Furthermore, species of concern including Virginia Rail (Rallus limicola) did not appear to be affected by P. australis (Gagnon Lupien et al., 2015). However, the authors did describe some subtle community changes: Marsh Wren appeared to prefer cattail over P. australis (possibly due to greater water depths in cattail habitat), while Yellow Warbler was more abundant in P. australis (Gagnon Lupien et al., 2015). The reason for these conflicting observations is uncertain, though analysis of bird communities rather than simply richness and abundance would likely yield greater insight. Current hypotheses for why some studies find more substantial changes in bird use following invasion than others, even within the same region, suggest that the response of the bird community to $P$. australis invasion may depend on the number or expanse of $P$. australis patches within marshes, the characteristics of $P$. australis patches, wetland water levels, and the life history of the birds being considered (Benoit and Askins, 1999; Chin et al., 2014; Gagnon Lupien et al., 2015; Whyte et al., 2015).

\subsubsection{Effects on avian food sources}

\subsection{2-a Invertebrates}

Birds are not the only wetland biota potentially affected by $P$. australis invasion. The changes caused by $P$. australis invasion are potentially capable of altering important invertebrate food sources, which could in turn affect food availability for birds. Fewer than 10 insect species are known to feed on $P$. australis in North America but the density of insects in P. australis stands 
can be high, with sensitivity varying by macroinvertebrate taxon (Chambers et al., 1999). Snails, amphipods, and isopods are common to abundant in $P$. australis habitat, exhibiting comparable abundances with resident marsh vegetation (Fell et al., 1998). This could be because P. australis provides better habitat for grazing invertebrates than cattail habitat: $P$. australis patches have exhibited high diatom density, and related high densities of snails (Holomuzki and Klarer, 2010). Overall macroinvertebrate densities were observed to be similar among P. australis, Typha spp. and native vegetation in a Lake Erie coastal marsh (Holomuzki and Klarer, 2010). Observations from saline environments also suggested that invertebrate density and diversity is insensitive to P. australis invasion (Able and Hagan, 2000; Warren et al., 2001), though in one study of tidal marshes Spartina alterniflora supported higher macroinvertebrate abundances and species richness than P. australis (Angradi et al., 2001). Phragmites australis habitat appears to support an adequate abundance of invertebrates within marsh systems, suggesting that any observed effects on waterbirds is not simply a product of changes to the quantity of their invertebrate food.

\subsection{2-b Fish}

Fish comprise a significant portion of the diet of many waterbirds, such as herons, egrets, Least Bittern, and American Bittern (Botaurus lentiginosus). Since Phragmites australis can fill-in open-water pools and reduce the depth of standing water (see below) within marshes, invasion has the potential to affect fish as a food source for these birds. However, studies comparing species composition and abundance of fish among P. australis, Typha angustifolia, and treated P. australis vegetation found no significant differences between vegetation types (Fell et al., 2003). Many studies on fish use in P. australis have occurred in tidal marshes, and focused on Fundulus heteroclitus (mummichog), a small saline tolerant killifish. Fundulus heteroclitus is 
abundant in P. australis, where fish are able to successfully forage, and there are no noticeable differences between the size of adult $F$. heteroclitus using $P$. australis and those using other vegetation (Chambers et al., 1999; Fell et al., 2003). These fish can also successfully lay and hatch eggs in $P$. australis, though low juvenile abundance suggests $P$. australis may not be suitable nursery habitat (Able and Hagan, 2003). However, earlier work with fish communities found that $P$. australis does not appear to have a negative effect on juvenile fish, including $F$. heteroclitus, or on larger fish (Able and Hagan, 2000). In freshwater lakes in Germany, fish may use $P$. australis stands during the day as the tall stems provide shelter from foraging birds (Okun and Mehner, 2005). Overall the differences in the use of $P$. australis by fish appears to be minimal, though few studies have focused on freshwater fish communities. While the interaction between $P$. australis and fish abundance is not entirely clear, it does appear that $P$. australis can support an adequate number of fish and, as with invertebrates, a change in use of the marsh by birds is unlikely to be mediated solely by fish availability.

\subsubsection{Effects on vegetation communities}

As noted previously, $P$. australis is able to colonize wetlands quickly and produce large patches, which can displace resident wetland plants (Ailstock et al., 2001; Trebitz and Taylor, 2007; Tulbure and Johnston, 2010; Whyte et al., 2008). The wide range of disturbances and environmental variables that $P$. australis can tolerate, coupled with its morphological characteristics, contribute to $P$. australis having a competitive advantage over many resident wetland plant species. In brackish tidal marshes $P$. australis spreads rapidly until it reaches an equilibrium point that consists of 50-80\% occupation of the marsh surface (Lathrop et al., 2003). With this level of occupation, $P$. australis invasion has a noticeable effect on the vegetation 
community in wetlands and has been noted to significantly reduce floristic diversity (Chambers et al., 1999; Keller, 2000). Decreases in plant species richness following invasion are most pronounced in freshwater marshes (Meyerson et al., 2000), where reductions in species richness are correlated to the density of $P$. australis stems (Lenssen et al., 2000; Price et al., 2014), suggesting an effect of competition between $P$. australis and native plant species. Some attribute this to the production of allelopathic gallic acid by invasive $P$. australis (Rudrappa et al., 2007; Uddin et al., 2014), thought this remains controversial (Weidenhamer et al., 2013). Given the rapid shoot production, long growing season, and great height and density of most $P$. australis; it is capable of decreasing available sunlight for native plants (Hirtreiter and Potts, 2012).

Above-ground, $P$. australis can reach 4 meters in height and patches have shoot densities ranging from $13-125$ stems per $\mathrm{m}^{2}$ (Meyerson et al., 2000). In Long Point, counts of living stems reached over 70 stems per $\mathrm{m}^{2}$, and living and dead stems combined reached over 190 stems per $\mathrm{m}^{2}$ (Rooney unpublished data). The height and density of $P$. australis allows it to dominate canopies (Minchinton and Bertness, 2003). In a comparison of light profiles between Typha spp. and P. australis patches in Long Point on average $31 \%$ of incident light reached the litter layer in Typha spp. compared to 17\% in P. australis (Robichaud unpublished data). Similar results were found in Lake Erie coastal marshes in New York, and suggests that the availability of light in Typha stands can be exploited by P. australis (Hirtreiter and Potts, 2012). For other species, shading can restrict the growth of shorter plants in P. australis patches, especially after mid-summer when day lengths shorten and light availability decreases (Haslam, 1971b). While the above-ground biomass of $P$. australis can alter light availability to other marsh plants, the rhizomes and roots of $P$. australis also contribute to its invasive potential. Phragmites australis can alter below-ground competitive interactions by producing extensive root and rhizome 
networks which reach up to $1 \mathrm{~m}$ in depth, and are typically deeper than resident plants (Moore et al., 2012). This consistently deeper root profile may circumvent nutrient competition for $P$. australis, and create niche differentiation among $P$. australis and resident wetland plants (Mozdzer et al., 2016).

There is also evidence that $P$. australis invasion may indirectly reduce native plant diversity. Muskrats are an important driver of plant diversity through canopy gap creation (Warren et al. 2001). Phragmites australis is known to be less palatable to muskrats, and the reduction in gap dynamics through muskrat exclusion may result in fewer bare patches and decreased opportunities for other wetland species to colonize invaded marshes (Warren et al. 2001).

Regardless of the mechanisms by which $P$. australis invasion leads to reduced floristic diversity, be they direct or indirect, it is evident that invasion often leads to substantial changes in wetland plant communities (Keller, 2000; Price et al., 2014; Wilcox et al., 2003). It is possible that reduced floristic diversity, the replacement of insect pollinated plants with wind pollinated $P$. australis, and the increased stem density and canopy closure would affect the marsh habitat value for waterbirds, especially marsh-nesting species that forage and build nests in emergent vegetation.

\subsubsection{Effects on ecological processes}

The changes to wetland plant communities following invasion by $P$. australis are known to significantly alter important ecological processes in wetlands. The introduction of non-native P. australis in a wetland ecosystem increases litter accumulation (Rooth et al., 2003; Windham, 2001), and $P$. australis stands directly increase the above- and below-ground biomass in aquatic 
ecosystems, with marshes exhibiting a 3 - 10-fold increase in above-ground biomass after $P$. australis colonization (Meyerson et al., 2000; Windham, 2001; Windham and Lathrop, 1999).

Not only does $P$. australis increase net primary production, but it also appears to reduce decomposition. The litter generated by tall, dense stands of $P$. australis has a direct effect on an ecosystem because it decomposes slowly: e.g., in a shallow freshwater lake P. australis leaves and stems took 242 and 574 days, respectively, to reach 50\% breakdown (Ágoston-Szabó and Dinka, 2008; S. R. Warren et al., 2001). Phragmites australis also reduces decomposition rates indirectly by shading soil and reducing soil temperature (Windham and Lathrop, 1999). Litter fills in substrate holes, smoothing microtopography and raising soil elevation which alters hydrology and lowers the depth of standing water in marshes (Able et al., 2003; Weinstein and Balletro, 1999; Windham and Lathrop, 1999). The net result is invaded marshes become drier and standing water becomes shallower over time, a change that could alter the use of marshes for birds that rely on standing water or the interface between emergent vegetation and open-water pools for foraging.

Phragmites australis may cause changes in wetland ecological processes, but these changes can take decades to become evident. In coastal tidal marshes, the peak standing crop of P. australis was tripled in 20 year old stands relative to five year old stands (Rooth et al., 2003). Lower standing water and smooth, elevated soil surfaces stabilize when stands are 8 to 15 years old in brackish tidal marshes (Windham and Lathrop, 1999), and 20 year old $P$. australis stands have levels of litter accretion $3-4 \mathrm{~mm} /$ year higher than adjacent younger stands (Rooth et al., 2003). Thus, we might expect that the effects of $P$. australis invasion will exhibit time lags, especially any indirect effects. For examples, if it takes 15 years for open-water patches to infill, 
any effects of invasion on waterbirds that are mediated by changes in the availability of openwater patches will not be immediately apparent.

\subsubsection{Effects on hydrology}

I described above mechanisms by which $P$. australis invasion can decrease the extent of standing water (Weinstein and Balletro, 1999; Windham and Lathrop, 1999), reducing the extent of openwater ponds and increasing the homogeneity of the marsh habitat. The roots of $P$. australis are dense and have very resilient rhizomes that stabilize soil and enhance gas diffusion into the rhizosphere (Bart and Hartman, 2003; Moore et al., 2012), and as described above, invasion tends to dry soils and infill open-water patches (Rooth et al., 2003; Windham and Lathrop, 1999). Within dense stands the accumulation of above-ground litter and below-ground material, driven by rhizomes mats, fills in creeks and standing water pools to the point where increases in marsh elevation make flooding rare (Able et al., 2003).

Phragmites australis can also alter run-off processes in invaded marshes. Raichel et al. (2003) observed that the smooth topography created by $P$. australis infilling encourages sheet flow which can cause faster water flow than typical rivulet hydrology (Raichel et al., 2003). In contrast, Weinstein and Balletro (1999) describe how the high stem density and litter density in P. australis can actually reduce run-off in invaded marshes.

These hydrologic changes combine to increase the aeration of wetland soils, which can reduce the anoxia stress experienced by wetland plant roots (Moore et al., 2012), potentially altering competition dynamics in an environment where resident plant species are adapted to inundated soils. With shallower standing water (Rooth et al., 2003), elevated and smoothed topography, and reduced flooding (Able et al., 2003) and surface run-off (Weinstein and 
Balletro, 1999), portions of the marsh may more closely resemble the upland environment. In terms of waterbirds, this can reduce habitat availability for waterfowl, herons, bitterns, and other species that preferentially use deeper water habitat. Whereas birds favoring robust emergent vegetation with less sensitivity to water levels, such as sparrows, blackbirds and warblers, may gain habitat following $P$. australis invasion.

\subsection{Conclusion}

The marshes of Long Point comprise a significant portion of the total wetland habitat along the north shore of Lake Erie, and represent bird habitat of international importance. A number of marsh-nesting bird species rely on these marshes for breeding, including the threatened Least Bittern. However, the vital role these marshes play is threatened by an on-going invasion of $P$. australis. This introduced aquatic grass is capable of converting diverse marsh vegetation communities into $P$. australis dominated habitat in just a few years. After invading a wetland, $P$. australis has been documented to reduce standing water, fill in open-water pools, decrease floral diversity, produce high rates of litter, and create dense stands that impede faunal movement. Despite these reported ecosystem effects, research conducted over 12 years ago in Long Point during the earlier stages of invasion, found that $P$. australis provided suitable habitat for many birds. While $P$. australis supported fewer marsh-nesting species individuals, overall P. australis supported higher total abundance and species richness than cattail or meadow marsh.

\subsection{Thesis structure}

In chapter 2, I seek to characterize the effects of $P$. australis invasion on bird use within Long Point marshes after over 12 years of invasion progression. The objective of this chapter is to 
compare the bird abundance, species richness, and community composition of birds using invaded habitat with those using uninvaded habitat within the marshes of Long Point by contrasting $P$. australis, cattail, meadow marsh, and open-water habitat. My work is designed to build on the work by Meyer et al. (2010), while addressing gaps in the original study design. Because of $P$. australis' ability to fill in open-water pools, I have added an assessment of openwater ponds in Long Point that are threatened by on-going P. australis advancement. I hypothesize that 1) marsh-nesting birds will be less diverse and less abundant within $\boldsymbol{P}$. australis stands than other vegetation types. As observed by Meyer et al. (2010) and Schummer et al. (2012) in Long Point, I anticipate that after 12 years of invasion P. australis stands may support fewer marsh-nesting individuals than uninvaded habitat. I hypothesize that 2) overall bird diversity in $P$. australis will be lower than other vegetation types, and bird species observed in $P$. australis will be a subset of birds seen in cattail and meadow marsh habitat. Based on work which observed few novel or rare species utilizing $P$. australis, but rather birds that have a wide distribution within the marsh such as Red-winged Blackbirds (Benoit and Askins, 2002; Wells et al., 2008; Whyte et al., 2015), I anticipate that most of the birds using $P$. australis in Long Point will be present in other vegetation types.

I also want to examine if a beneficial edge effect still occurs between vegetation types after invasion has progressed, so I will contrast bird use based on location - whether a stand is edge habitat, within $50 \mathrm{~m}$ of another habitat type, or interior, greater than $50 \mathrm{~m}$ from another vegetation type in accordance with Meyer et al. (2010). I hypothesize that 3) that the abundance and diversity of birds will be higher in the edge stands of all three habitat types. Some studies have found birds use these habitat boundaries frequently, even if they do not use the interior of P. australis patches (Benoit and Askins 1999, Meyers et al. 2010, Schummer et al. 
2012). In addition to bird abundance and richness, I want to examine the effects that $P$. australis may have on bird communities by assessing the effects on bird species composition and functional traits (e.g. diet, foraging strategy, nesting behaviour). I hypothesize that 4) P. australis habitat will support a community of birds that eat insects and are shrub nesters. I expect that birds that forage using stalking or probing will find dense patches of P. australis difficult foraging habitat, and that $P$. australis stands may be drier and not support the food sources certain stalking or probing species require. Further, other studies have suggested that $P$. australis does not provide suitable habitat for ground nesting birds, as many ground nesters prefer dense grass and sedge meadow rather than the stiff stem and leaf material of $P$. australis (Meyer et al., 2010; Riffell et al., 2001).

In chapter 3, I present a synthesis of my findings, suggestions for measuring effects of invasion on bird communities, and comment on the implications and significance of this research in the context of wetland management in the face of biological invasions. 


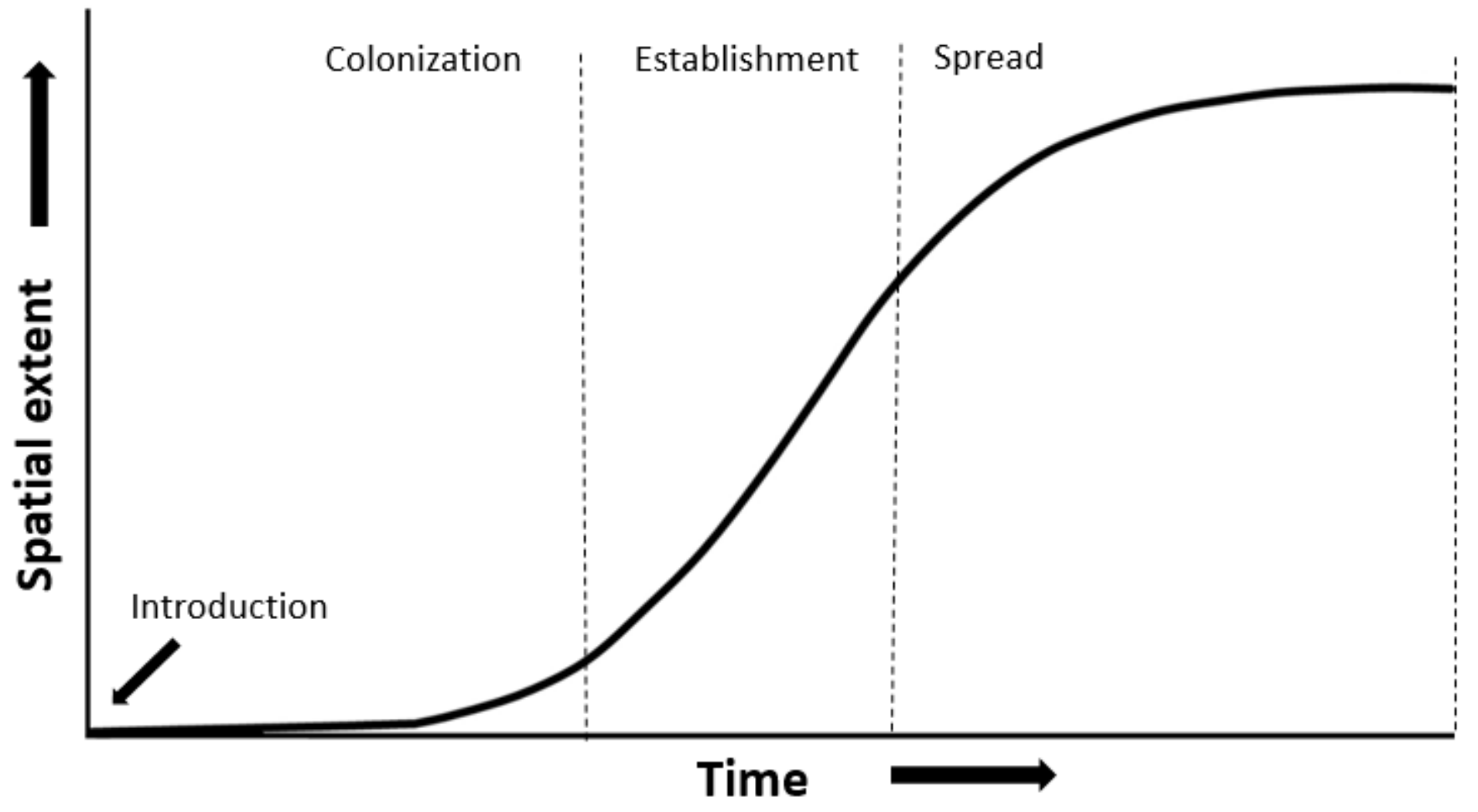

Figure 1-1. Invasion curve identifying the stages of invasion: introduction, colonization, establishment and spread. Figure adapted from Theoharides and Dukes, 2007 and Davis, 2009. 


\subsection{Effects of Phragmites australis invasion on bird communities in Long Point, ON}

\subsection{Introduction}

The introduced clonal grass Phragmites australis (hereafter P. australis) is aggressively colonizing freshwater coastal marshes and displacing resident vegetation communities with dense, monotypic stands (Trebitz and Taylor 2007; Whyte et al. 2008; Tulbure and Johnston 2010). Phragmites australis out-competes the plant species historically characteristic of cattail marsh and meadow marsh habitats (Wilcox et al., 2003) and fills in open-water pools (Able et al., 2003). Not only does this reduce floristic diversity (Keller, 2000), but invasion has the potential to threaten the highly-valued coastal-marsh habitat used by unique wetland birds, including species at risk like Least Bittern (Ixobrychus exilis). Recent declines in marsh bird occupancy, specifically Virginia Rail (Rallus limicola), in Great Lakes coastal wetlands have been attributed in part to invasion by $P$. australis (Tozer, 2016). However, research into the effects of P. australis invasion on bird use sometimes suggests that the results of invasion are benign (e.g. Meyer et al., 2010).

As the $P$. australis invasion expands, it alters environmental conditions in the marsh. For example, the horizontal leaf orientation of $P$. australis combines with its rapid growth and great canopy height to lower light availability under the canopy (Hirtreiter and Potts, 2012; Minchinton et al., 2006). We measured light extinction in 15 plots of Typha spp. and $15 P$. australis stands in Long Point, Ontario on Lake Erie, and found that on average 31\% $( \pm 22)$ of incident light reached the litter layer in Typha spp., compared with $17 \%( \pm 18)$ in P. australis (Rooney unpublished data). Stem counts find that invasive $P$. australis stands are denser than the native lineage of $P$. australis: typically, around 28 live stems per $\mathrm{m}^{2}$ (Holdredge and Bertness, 
2011; Price et al., 2014) or around 80 stems per $\mathrm{m}^{2}$ when considering both living and dead biomass (R. S. Warren et al., 2001). In Long Point, established P. australis patches had stem densities of up to 76 live stems per $\mathrm{m}^{2}$ and over 190 stems per $\mathrm{m}^{2}$ where live and dead stems were both counted (Rooney unpublished data). The net result is that marsh habitat invaded by $P$. australis is darker and denser. It has been argued that the density of stands and rigidity of stems can make the habitat impenetrable to large-bodied waterbirds (Benoit and Askins, 1999; Kessler et al., 2011). Further, the increased above-ground biomass couples with high litter accumulation (Rooth et al., 2003; Windham, 2001) to smooth microtopography, raise soil and reduce standing water levels (Lathrop et al., 2003; Weinstein and Balletro, 1999; Windham and Lathrop, 1999), eliminating open-water pools and creeks (Able et al., 2003). Standing water and open-water pools are essential habitat for waterbirds and shorebirds, contributing to the overall heterogeneity of marshes and correlating with an increase in bird species richness, especially in meadows (Benoit and Askins, 1999; Riffell et al., 2001). These changes in habitat quality and loss of openwater habitat could affect bird use in invaded marshes.

Indeed, multiple studies have examined the effects of $P$. australis invasion on the abundance and richness of birds (Benoit and Askins, 1999; Gagnon Lupien et al., 2015; Meyer et al., 2010; Schummer et al., 2012; Wells et al., 2008; Whyte et al., 2015), but with conflicting results. Some authors show substantial changes in bird abundance (Schummer et al., 2012; Whyte et al., 2015) whereas others find little effect on bird use (Gagnon Lupien et al., 2015). Further, species richness has been found to increase with some studies (Meyer et al., 2010), and decrease with others (Benoit and Askins, 1999), making it difficult to tease apart the effects of $P$. australis invasion on wetland birds. 
Over a decade ago, emerging concerns about $P$. australis invasion in Long Point, Ontario prompted a study by Meyer et al. (2010) examining the effects of invasion on bird abundance and species richness. Though present in Long Point since before 1945, the population of invasive P. australis began to grow exponentially in Long Point in the late 1990s (Wilcox et al. 2003). Long Point is a sandspit extending into Lake Erie from the Canadian shore. Its inner margin supports valuable coastal marsh that comprises more than $70 \%$ of the wetland habitat on the north shore of Lake Erie (Ball et al., 2003) and it provides essential habitat for numerous marshnesting bird species. Its position and size make it a critical stopover for hundreds of migrating bird species using the Atlantic flyway (Bird Studies Canada, 2016). It has been consequently designated as a Ramsar wetland, a UNESCO World Biosphere Reserve, and an Important Bird Area.

Based on surveys conducted in 2001 and 2002, Meyer et al. (2010) found that the total abundance and species richness of birds were higher in $P$. australis than in uninvaded cattail and meadow marsh habitats. In addition, the authors reported a strong, positive edge-effect, whereby the total abundance and species richness of birds was highest in P. australis stands that were within $50 \mathrm{~m}$ of a different vegetation type. Although they noted that more marsh-nesting birds used meadow marsh, overall $P$. australis appeared to provide suitable habitat for many birds (Meyer et al., 2010). More recently, Gagnon Lupien et al. (2015) also reported minimal effects of $P$. australis invasion on the bird communities in marshes in southwestern Quebec. In contrast, research from Virginia (Paxton, 2006), New York (Wells et al., 2008) and Connecticut (Benoit and Askins 1999) report that generalist bird species like Red-winged Blackbird (Agelaius phoeniceus) increase in abundance following $P$. australis invasion at the expense of wetland 
specialists like Virginia Rail and Least Bittern. These authors conclude that $P$. australis invasion reduces the value of marsh habitat to birds.

One possible explanation offered for the discrepancy is that the effect of $P$. australis invasion on birds may exhibit a time lag, and changes to the bird community may become more evident as the invasion progresses (Gagnon Lupien et al., 2015). During the decade since the Meyer et al. (2010) study, P. australis has spread in Long Point unchecked, allowing stands to increase in size and density. Research from McMaster University indicates that $P$. australis is still rapidly expanding in Long Point (Marcaccio and Chow-Fraser, 2016). I sought to determine whether the bird community is now experiencing more notable changes, and thus repeated the assessment by Meyer et al. (2010) thirteen years after their field work was conducted.

The purpose of my study was to understand the effect that long-term, uncontrolled invasion has on bird abundance and diversity, both in terms of total birds and marsh-nesting species. Studies reporting more substantial effects of $P$. australis invasion on bird use typically observed a shift in community composition, rather than a decrease in total abundance or diversity (but see Wells et al. 2008). Thus, I also tested for changes in community composition, particularly those that alter the balance of bird functional traits, such as nesting preferences, diet, or foraging behaviour. Such changes would have ramifications for coastal marsh ecological processes and function. Further, I added bird surveys in open-water habitat to the experimental design employed by Meyer et al. (2010), since the loss of open-water associated with $P$. australis invasion could have important consequences for bird communities that would go undetected if open-water habitat was not considered. 


\subsection{Methods}

\subsubsection{Field methods}

Surveys took place in 2015 and spanned three management zones in Long Point, ON - Big Creek National Wildlife Area, Crown Marsh, and Long Point Provincial Park (Fig. 2-1). According to the Great Lakes Water Level dashboard (Gronewold et al., 2013), Lake Erie water levels were high in 2015, peaking at $60 \mathrm{~cm}$ above average in July.

I did not have access to the original data from Meyer et al. (2010), but sought to replicate the design of the study as closely as possible. In 2014, I revisited the point count locations in Long Point Provincial Park and Crown Marsh that Meyer et al. (2010) sampled in 2001 and 2002. Of the original 36 sites I surveyed, 20 were now invaded by $P$. australis in contrast with six reported as invaded in 2002. New sites were established to rebalance the experimental design. Further, I incorporated open-water habitat in the form of small pools and channels occurring in the marsh as a new vegetation type in the design.

In 2015, I surveyed 48 fixed-distance point count locations, 22 of which had been used by Meyer et al. (2010) and 26 that were newly established (Fig. 2-1; Appendix 8). Point count locations were established in late April and were located a minimum of $200 \mathrm{~m}$ apart from each other to ensure independence in bird observations, in keeping with similar studies (e.g., Benoit, L.K., Askins 1999; Meyer et al.2010). Twelve point counts were located within each of four vegetation types: 1) P. australis, 2) cattail marsh, 3) meadow marsh, and 4) open-water (Appendix 3). Of each set of twelve point count locations, six were situated within $50 \mathrm{~m}$ of another habitat type (edge) and six were situated greater than $50 \mathrm{~m}$ from any other habitat type (interior). An exception was that all twelve open-water point count locations were situated in edge territory, as the open-water pools or channels were less than $50 \mathrm{~m}$ across and incorporated 
both open-water and emergent vegetation within the point count diameter. Since no patch of open-water was large enough to be greater than $50 \mathrm{~m}$ from another habitat type on all sides, it was impossible to separate these sites into "interior" open-water and "edge" open-water.

I surveyed vegetation at each point count location in mid-August to facilitate bird habitat characterization. Three $1 \mathrm{~m}^{2}$ quadrats were established $10 \mathrm{~m}$ from the center of the point count location and the average canopy height, percent cover of plant species, and water depth were recorded to characterize the habitat present at each point count location. In general, meadow marsh point count locations were characterized by shallow standing water or saturated soils, and dominated by hummock forming grasses (Calamagrostis canadensis) and sedges (Carex spp.) (Appendix 3-C). Cattail marsh point count locations were inundated throughout the growing season and dominated by Typha spp. (Appendix 3-B), while P. australis point count locations spanned a moisture gradient between cattail marsh and meadow marsh soil-saturation levels and were dominated by the invasive $P$. australis haplotype (Appendix 3-A). Open-water point count locations were pools or slow moving channels within the marsh complex characterized by lilies (Nuphar lutea and Nymphaea odorata), Potamogeton spp., and Chara spp. (Appendix 3-D, Appendix 4).

I surveyed birds at each point count four times throughout the summer (May to early August 2015), separated by a minimum of 10 days. Surveys followed the protocol adopted by Meyer et al. (2010) and the recommendations of Bird Studies Canada (2009). In brief, between half an hour after sunrise and 09:30, point count surveys took place from an established center point on a $1.8 \mathrm{~m}$ ladder to standardize observer height and vantage point, as canopy height differs by vegetation type (Table 2-1). All individual birds seen or heard within a $25 \mathrm{~m}$ radius around the center point, or actively foraging within $100 \mathrm{~m}$ above were identified and recorded. Birds that 
flew over or through the survey site without using it were noted but not used in data analysis. Surveys were 15 minutes in length and consisted of 5 minutes of passive listening, 5 minutes of call broadcasting for secretive birds, including Virginia Rail, Sora (Porzana carolina), Least Bittern, a combination of Common Moorhen (Gallinula chloropus) and American Coot (Fulica americana), and Pied-billed Grebe (Podilymbus podiceps), and a final 5 minutes of passive listening.

\subsubsection{Statistical methods}

Birds were classified as marsh-nesters if they nest in wetlands, or generalists if they do not require wetlands for nesting, in keeping with the classification by Meyer et al. (2010) (Appendix 5). Marsh-nesting species in decline in the lower Great Lakes (Tozer, 2016) were further classified as marsh-nesting species of concern (Appendix 5). Analyses were performed on six response variables: total bird abundance, total species richness, marsh-nesting bird abundance, marsh-nesting species richness, bird community composition, and functional trait composition. Functional traits included foraging behaviour (e.g., ground forager, stalking, aerial forager), diet (e.g., insects, seeds, fish) and nesting preferences (e.g., cavity, shrub, ground), in agreement with traits reported in the Birds of North America Online resource (Rodewald, 2015). Bird counts were summed across all survey dates to capture birds that call or use the marsh at different times in the summer (Appendix 6). 


\subsection{2-b Abundance and species richness}

First, the total abundance of birds of each species was summed for each point count to generate the total bird abundance values. Second, to calculate the abundance of marsh-nesting birds, only the abundance of species identified as marsh-nesters in Appendix 5 were summed. Third, the total number of species observed at each point count throughout the summer was summed to represent bird species richness. Finally, the total number of marsh-nesting species at each point count was summed to determine marsh-nesting bird species richness. All univariate analyses were performed using R (R Core Team 2016).

To determine whether bird abundances or species richness differed among the four vegetation types ( $P$. australis, cattail marsh, meadow marsh, open-water) I used a one-way ANOVA with type III sums of squares. To evaluate differences in bird abundance or species

richness between edge and interior loci, I assessed only $P$. australis, cattail marsh, and meadow marsh vegetation types as all open-water sites were edge habitat. I conducted a two-way ANOVA with an interaction term, with locus and vegetation type as factors. I found that the interaction term was not significant so I used type II sums of squares in the two-way ANOVAs. For both one-way and two-way ANOVAs, a Tukey's pairwise comparison was performed when F-values were significant $(\mathrm{p}<0.05)$.

\subsection{2-c Community composition and functional traits}

I performed multivariate analyses to characterize the differences in bird community composition and functional traits in different vegetation types and between loci, using PC-ORD (McCune and Mefford, 2011). Data underwent general relativization to reduce the influence of highly abundant species, such as Red-winged Blackbirds. In addition, I excluded rare species ( $<2$ occurrences) to reduce data sparsity prior to ordinations, as recommended by Peck (2010). 
To visualize differences in community composition and functional traits, I calculated Bray-Curtis dissimilarity matrices (Bray and Curtis, 1957) for both species counts and counts of different functional traits, and performed non-metric multidimensional scaling ordination (NMS) on each matrix separately. Each point in the NMS figures represents a point count location, and they are positioned such that proximity in the figure is correlated with similarity in either community composition or functional traits, depending on which matrix was used in the NMS. The best ordination solutions were determined using an iterative process with a random starting configuration, comparing solutions with one to four dimensions, using 50 runs with real data and 50 runs with random data. The best fitting ordination solution for each matrix was re-run to quantify the stress and instability of the final solution. Two meadow marsh sites had undue influence on axis 1 for both species abundance and functional traits, so I re-ran the ordination excluding these sites. Their removal did not alter the interpretation of the ordinations, so I present the ordinations excluding these two sites.

Since open-water habitat did not permit interior point count locations, analyses including the open-water vegetation type could not consider the factor locus. Hence, a multi-response permutation procedure (MRPP) with a Bray-Curtis distance measure (Zimmerman et al., 1985) was used to assess the significance of differences among bird assemblages in open-water, meadow marsh, cattail marsh, and $P$. australis vegetation types.

MRPP permits an unbalanced design; however, where a balanced two-factor experimental design is possible (i.e., where only meadow marsh, cattail marsh, and P. australis vegetation types were contrasted) permutational MANOVA (perMANOVA) is preferable because it allows the analysis of a two-factor design with an interaction term (Anderson and Walsh, 2013; McCune and Grace, 2002). Thus, for the P. australis, meadow marsh and cattail 
marsh vegetation types, which possessed both interior and edge habitats, the significance of observed differences in community composition among vegetation type, locus, and their interaction (i.e., whether the influence of vegetation type on community composition differed between loci) were tested using perMANOVA where there were equal numbers of point counts per treatment (Anderson, 2001).

\subsection{2-d Vegetation analyses}

The relative cover of the dominant plant species within each vegetation type was calculated based on the total vegetation cover, excluding bare soil and litter. Simpson's reciprocal diversity index was calculated as described in Hill (1973) as

$$
1 / \sum(n / N)^{2}
$$

\subsection{Results}

I observed 32 bird species, including 12 marsh-nesting species (Appendix 4), during the 2015 field season. In total, 22 species were found in open-water, 21 in meadow marsh, 17 in cattail marsh, and 13 in P. australis (Appendix 6). In comparison, Meyer et al. (2010) found 28 bird species in meadow marsh, 18 in cattail marsh, and 27 in $P$. australis during the breeding season. The four vegetation types differed in terms of habitat structure as well as dominant vegetation species (Table 2-1, Appendix 4). 


\subsubsection{Abundance and species richness}

The interaction terms for total abundance and species richness were never significant $(\mathrm{p}>0.05)$, nor was locus ( $\mathrm{p}>0.05)$; however, I observed significant differences in abundance among vegetation types (Table 2-2; Fig. 2-2B). For marsh-nesting bird abundance and species richness the interaction term was never significant $(\mathrm{p}>0.05)$, nor was locus $(\mathrm{p}>0.05)$, nor vegetation type ( $p>0.05)$. However significant differences in marsh-nesting bird abundance were observed when open-water was considered (Table 2-2; Fig. 2-3B), as open-water habitat supported the fewest individuals but an equivalent number of species as other vegetation types. Phragmites australis patches support fewer individuals than meadow marsh, and significantly fewer individuals than cattail marsh habitat.

The abundance of marsh-nesting birds was significantly $(\mathrm{p}=0.002)$ influenced by vegetation type when open-water was considered, and driven by the difference between openwater and cattail marsh. The number of individual marsh nesters and marsh-nesting species were comparable between cattail marsh, meadow marsh, and P. australis (Figure 2-3).

\subsubsection{Community composition and functional traits}

The optimal NMS ordination of the community composition dissimilarity matrix had two dimensions, with an acceptable final stress (18.54) and a final instability of $<0.001$ after 61 iterations. This ordination solution explained $77 \%$ of the variance in community composition; $52 \%$ on axis 1 and $25 \%$ on axis 2 (Fig. 2-4). Note that I tested the sensitivity of the general conclusions to the inclusion of open-water point count locations in the NMS by repeating the ordination without the open-water data and found the general interpretation unchanged (Appendix 7). 
A strong moisture gradient is correlated with the differences in community composition summarized by Axis 1, separating deeper open-water sites from the shallower point count locations. Meadow marsh is the shallowest of the four vegetation types, while $P$. australis grows in a range of water depths (Table 1). Consequently, there is overlap in bird community composition between $P$. australis point count locations and those in cattail marsh and meadow marsh on Axis 1. Axis 1 reflects a trend in the abundance of smaller-bodied marsh-nesting species Common Yellowthroat (Geothlypis trichas) and Swamp Sparrow (Melospiza georgiana), which are associated with shallower areas with more vegetation ground cover. Due to the differences in species composition and lower abundance of birds using the open-water pools and channels, open-water point count locations also group separately on Axis 1. Open-water sites support waterfowl not found in any other vegetation type. There is some overlap between cattail marsh and open-water point count locations, as open-water locations included emergent vegetation and cattail marsh also provides areas of deeper water that support species such as Marsh Wren. Axis 2 in the ordination is driven by trade-offs between Canada Goose (Branta canadensis) and Wood Duck (Aix sponsa), and swallows (Hirundinidae), with the aerial foraging swallows associating with open-water and meadow marsh point count locations (Fig. 2-4). Other aerial insectivores that hunt via fly-catching, Willow Flycatcher (Empidonax traillii) and Eastern Kingbird (Tyrannus tyrannus), used $P$. australis in addition to meadow marsh and cattail marsh. Canada Goose and Wood Duck are strongly associated with open-water habitat, rarely using any other vegetation type. Swamp Sparrow, in contrast, was more abundant in meadow marsh, and rarely used open-water locations. Swamp Sparrow is also more associated with meadow marsh than Common Yellowthroat, though both species occurred more often in meadow and cattail marsh than in P. australis. 
In visualizing patterns in bird functional traits, the optimal NMS solution had three dimensions with low final stress (9.59) and a final instability of $<0.001$ after 90 iterations. The ordination solution explained a cumulative $92 \%$ of the variance; $68 \%$ axis $1,15 \%$ axis 2 , and $8 \%$ axis 3 (Fig. 2-5). As in the ordination on species composition, Axis 1 was strongly correlated with a water depth: deeper open-water point count locations separated from cattail marsh, $P$. australis, and meadow marsh. Axis 2 reflects differences in diet and foraging behaviours, with $P$. australis sites clustering closely together. Birds that consume plants, fish, or seeds and utilize stalking or dabbling foraging techniques were associated with open-water or deeper cattail marsh. Birds that forage on the ground (gathering food from shallow water or low branches) or glean from foliage and mainly consume insects are found in shallower vegetation types. The third axis is driven by aerial foragers associating with open-water and meadow marsh, and ground nesting species associating with open-water habitat. Insectivorous, shrub nesting, foliage gleaning or ground foraging species are associated with drier vegetation types, and are not found using open-water or deeper cattail marsh sites as frequently. On axis 2 meadow and cattail marsh sites are more spread out, while $P$. australis sites remain clustered on both axes.

For both community composition and functional traits, I observed no significant interaction between locus and vegetation type (perMANOVA on community composition: $\mathrm{p}>$ 0.05; perMANOVA on functional traits: $\mathrm{p}>0.05$ ), or locus (perMANOVA on community composition: $\mathrm{p}>0.05$, perMANOVA on functional traits: $\mathrm{p}>0.05)$. Both the perMANOVA (contrasting $P$. australis, cattail and meadow marsh) and MRPP (contrast all four vegetation types) found that vegetation type was a significant predictor of bird community composition and functional traits (Tables 2-3, 2-4). Pair-wise comparisons of vegetation types reveal that the bird 
communities associated with each vegetation type are distinct, but the bird communities in meadow and cattail marsh possess similar functional traits.

\subsection{Discussion}

Long Point, Canada is highly acclaimed as a biodiversity hotspot, bird stop-over and breeding site, but this Ramsar wetland, UNESCO World Biosphere Reserve, and Important Bird Area is threatened by an extensive and largely unmitigated invasion of European Phragmites australis. Several previous studies, including research in coastal wetlands along the Ohio shore of Lake Erie (Whyte et al., 2015) and in freshwater marshes in southwestern Quebec (Gagnon Lupien et al., 2015), concluded that the effects of $P$. australis on bird use in invaded wetlands were limited. In Long Point itself, a study carried out 2001 and 2002 reported an increase in bird abundance and species richness associated with $P$. australis patches compared with the historically dominant cattail and meadow marsh vegetation communities (Meyer et al., 2010). They also found that the edges of stands (within $50 \mathrm{~m}$ of another vegetation type) supported more bird species than interior habitats. In contrast, I found lower total abundance of birds in $P$. australis than either cattail or meadow marsh (Table 2-4). In some studies, where bird abundance increased with $P$. australis invasion, this was attributed to high numbers of Redwinged Blackbirds (Wells et al. 2008, Whyte et al. 2015). Although I observed high abundances of Red-winged Blackbirds in every vegetation type, they were less abundant in P. australis than either cattail or meadow marsh in 2015 (Appendix 6). Further, I did not observe the positive edge-effects reported by Meyer et al. (2010), detecting no difference in bird abundance, richness, or community composition between the interior and edges of the marsh vegetation types possessing interior points. 
I suspect the reason there no longer appears to be an increase in abundance or richness of birds associated with $P$. australis or with habitat edges is that in the 13 years since the Meyer et al. (2010) bird surveys, $P$. australis cover has expanded and become denser. In the early stages of invasion when patches are relatively thin, $P$. australis may have contributed to overall habitat heterogeneity and provided structural diversity that is no longer present now that patches are over a decade old (Rooth et al., 2003). Supporting this hypothesis, Gagnon Lupien et al. (2015) attribute their finding that $P$. australis had no severe effect on bird use in southwestern Quebec marshes to the early stage of invasion in their study system. As $P$. australis expands, replacing meadow marsh and cattail marsh, it smooths and elevates substrate, filling in small holes and open-water pools through litter accumulation (Weinstein and Balletro, 1999; Windham and Lathrop, 1999), reducing floral diversity, and creating dense stands of stiff stems (Ailstock et al., 2001; Schummer et al., 2012; Windham, 2001). These changes alter marsh habitat making it less heterogeneous. Bird species like Swamp Sparrow, Virginia Rail, and American Bittern (Botaurus lentiginosus), which prefer sedges and grasses, open-water pools, and more ground cover when selecting nesting sites (Riffell et al., 2001), therefore lose habitat area as the $P$. australis invasion becomes more established. I suspect that the loss of edge effects in Long Point is also due to the maturation of $P$. australis in the last decade. The continued growth and infilling of $P$. australis patches over time shortens the length of the ecotone between vegetation patches from a gradual gradient to an abrupt border.

In assessing the effects of invasion on any biological community, it is important to consider not only species richness, but also community composition. Species richness can be useful in describing marsh biodiversity, but it may obscure the impact of a biological invasion. This study is not alone in finding little difference in bird richness between invaded and resident 
vegetation types (Gagnon Lupien et al., 2015; Whyte et al., 2015). A decline in the abundance of a species, without it being extirpated, or a switch from a sensitive specialist species to a more generalist one will not register in the measure of species richness, making it an insensitive metric. The bird community composition within a wetland is more sensitive to ecological changes than bird species richness, and should therefore be considered in determining the effects of $P$. australis invasion.

I found that bird community composition was influenced by $P$. australis, leading to further changes in bird community functional traits, i.e. the roles birds perform within the ecosystem. Bird communities using open-water, cattail marsh, meadow marsh, and P. australis stands are each distinct. However, the bird community in P. australis is not supporting novel species, but rather a novel community made up of borrowed parts. Within P. australis, the most abundant species observed were Common Yellowthroat, Swamp Sparrow, Marsh Wren (Cistothorus palustris), Red-winged Blackbird, and Yellow Warbler (Setophaga petechia). Excluding Yellow Warbler, all of these species were more abundant within cattail marsh or meadow marsh than in $P$. australis. The mixing of bird communities in $P$. australis could be attributed to its wide range of tolerance of soil moisture level (Engloner and Papp, 2006; Vretare et al., 2001) such that $P$. australis grows in areas formerly occupied by drier meadow marsh and by inundated cattail marsh. In Long Point in 2001-2002 (Meyer et al. 2010) and in southwestern Quebec (Gagnon Lupien et al., 2015) P. australis supported high numbers of Yellow Warbler, likely because this species nests in shrubs and trees, which can be mimicked by the stiff stems and density of $P$. australis stands (Gagnon Lupien et al., 2015; Lowther et al., 1999). Phragmites australis habitat can also provide an adequate abundance of insects to support Yellow Warbler's 
diet, and the physical structure of $P$. australis allows foliage gleaners access to this food supply (Holomuzki and Klarer, 2010; Lowther et al., 1999).

Vegetation type did not yield a strong influence on marsh-nesting bird abundance or species richness, but when considering community composition and functional traits it is evident that the type of marsh-nesting species found in cattail marsh, meadow marsh, and open-water vegetation differed from those found in $P$. australis. The only marsh-nesting birds observed in $P$. australis (Common Yellowthroat, Swamp Sparrow, and Marsh Wren) were all small-bodied, shrub-nesting birds that primarily glean insects from plants (Guzy and Ritchison, 1999; Kroodsma and Verner, 2014; Mowbray, 1997). Foliage gleaning may be easier than other foraging strategies in $P$. australis, where the density of $P$. australis stems can make it difficult to maneuver, especially for larger-bodied birds (Benoit and Askins, 1999). Species such as Great Blue Heron (Ardea herodias), Sora, American Bittern, Least Bittern, Sandhill Crane (Grus canadensis), and Virginia Rail occurred only in cattail marsh, meadow marsh or open-water vegetation types. Specifically, marsh-nesting species of concern (Virginia Rail, American Bittern, Least Bittern) were not recorded using P. australis during the sampling period (Appendix 6). In terms of traits, species that rely on stalking or dabbling for foraging and nest on the ground were more strongly associated with meadow marsh, cattail marsh and open-water habitat than with $P$. australis. This includes the marsh-nesting species Virginia Rail, Sora, and Least Bittern, who forage for food by probing, ground foraging and stalking, respectively, and preferentially build ground nests using cattail vegetation or sedges (Conway, 1995; Melvin and Gibbs, 2012; Poole et al., 2009). American Bittern, a species observed only in cattail marsh and open-water, is also a ground nesting bird who forages via stalking and has been reported to avoid dense, even-aged stands of vegetation when hunting (Lowther et al., 2009). Similarly, aerial 
insectivores like Barn Swallows (Hirundo rustica) were most abundant foraging over open-water and meadow marsh. Along the southern shoreline of Lake Erie, $P$. australis did not appear to negatively affect macroinvertebrate density, which suggests $P$. australis stands can provide an adequate food supply for birds (Holomuzki and Klarer, 2010). It is possible the dense aboveground stands may limit emergence or availability of macroinvertebrates for aerial foragers. Additional work is necessary to determine why these birds are not using $P$. australis habitat.

The use of open-water habitat by birds was not examined by Meyer et al. (2010), although another study conducted in Long Point compared birds in mixed-cattail habitat (Typha spp. and P. australis) with birds in open-water ponds (Schummer et al., 2012). This study concluded that total bird abundance was higher in open-water than in mixed-cattail habitat, and there were significantly more marsh-nesting individuals and species in open-water (Schummer et al., 2012). In contrast, I found lower abundance in open-water and no difference in marsh-nesting bird species richness among vegetation types. Yet, open-water sites support a distinct bird community, including marsh-nesting species such as American Bittern and Least Bittern, and other species such as Mallard (Anas platyrhynchos), Wood Duck (Aix sponsa), Blue-winged Teal (Anas discors), and terns (Laridae). The potential for P. australis to reduce the size of these areas or fill them entirely (Lathrop et al., 2003; Windham and Lathrop, 1999) is a threat to this open-water bird community.

The reduction in breeding habitat available for marsh-nesting birds due to $P$. australis invasion will have serious consequences for bird conservation, especially as many marsh-nesting species have already experienced significant declines around the Great Lakes (Tozer, 2016). Further, studies predict that $P$. australis will experience considerable expansion throughout the Great Lakes as climate change, altered flood regimes, and anthropogenic disturbances provide 
suitable habitat for colonization (Mazur et al., 2014; Tougas-Tellier et al., 2015). Understanding the implications of invasion on important biological communities is essential to management, as P. australis has the potential for regional or bi-national impacts.

In Long Point, as P. australis continues to replace scarce meadow and cattail marsh habitat, there may not be a reduction in species richness; however, the identity and functional traits of birds present in the marsh will shift to a mix of smaller-bodied, shrub-nesting generalists like Yellow Warbler and Common Yellowthroat. These results suggest that ground-nesting birds that forage by stalking or dabbling will be most affected, including the threatened Least Bittern. The impacts of $P$. australis invasion appear to have a lag time, as what seemed to be benign or even beneficial in the early stages of invasion now clearly has negative effects on bird use in Long Point. Destruction and fragmentation of the habitat that specialized birds require for reproduction may lead to time-delayed extinction (Kuussaari et al., 2009; Tilman et al., 1994), highlighting the need to preserve large areas of cattail marsh and meadow marsh within invaded coastal marsh habitats.

My work emphasizes the importance of considering the identity and functional traits of birds to fully comprehend the effects of an invasive plant. Phragmites australis can exclude sensitive species that have specific habitat requirements, replacing them with generalist species and causing a shift in bird community and the functional traits of birds. Species richness is an insensitive metric for determining the effects of biological invasion on an ecosystem because such shifts are not necessarily evident unless the identity and traits of affected communities are considered explicitly. Future monitoring efforts should incorporate a measurement of species composition, rather than focusing on abundance or species richness, to capture the subtler effects of biological invasion. 


\subsection{Figures and Tables}

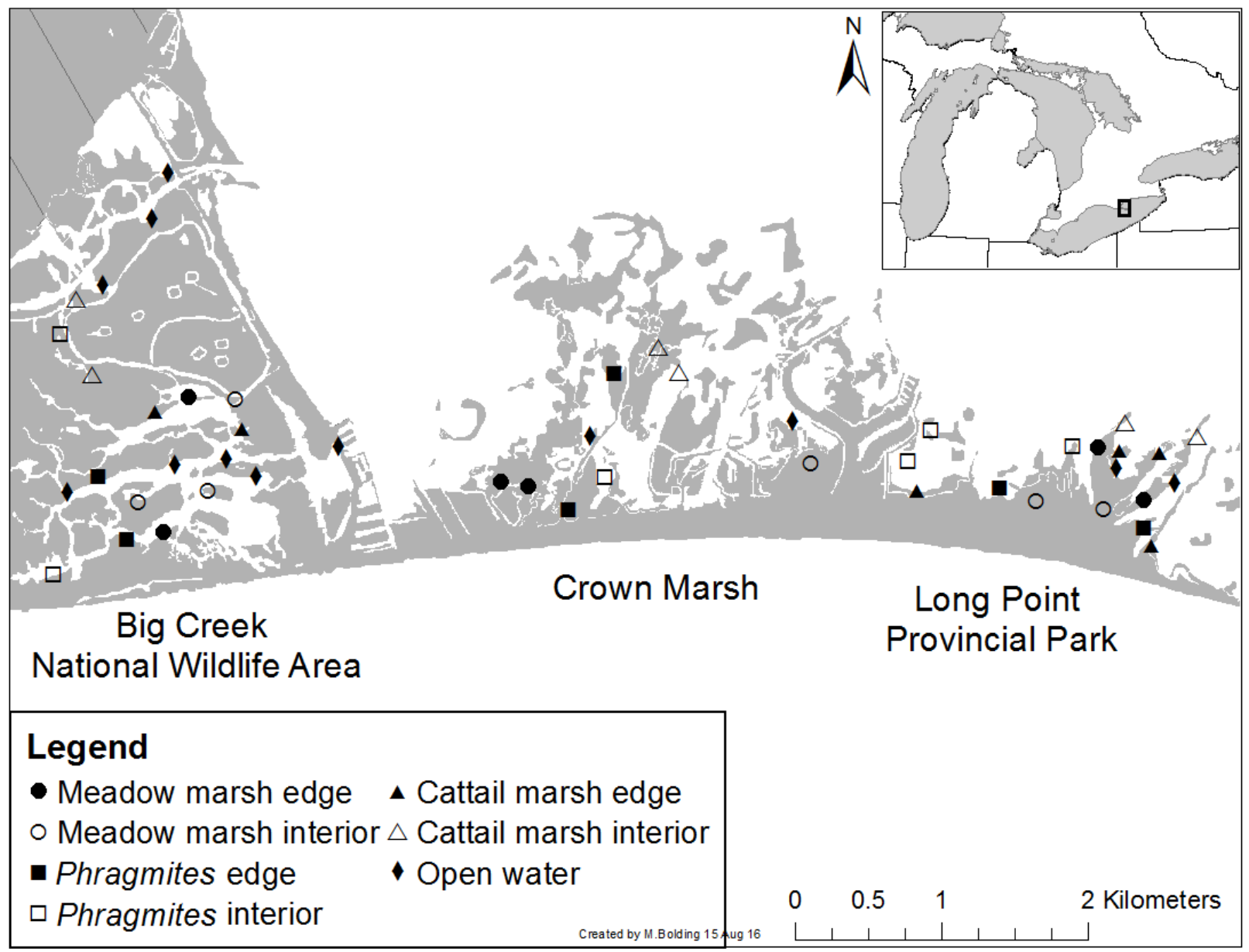

Figure 2-1 Bird survey point count locations within three management zones - Big Creek

National Wildlife Area, Crown Marsh, and Long Point Provincial Park - in Long Point, ON 

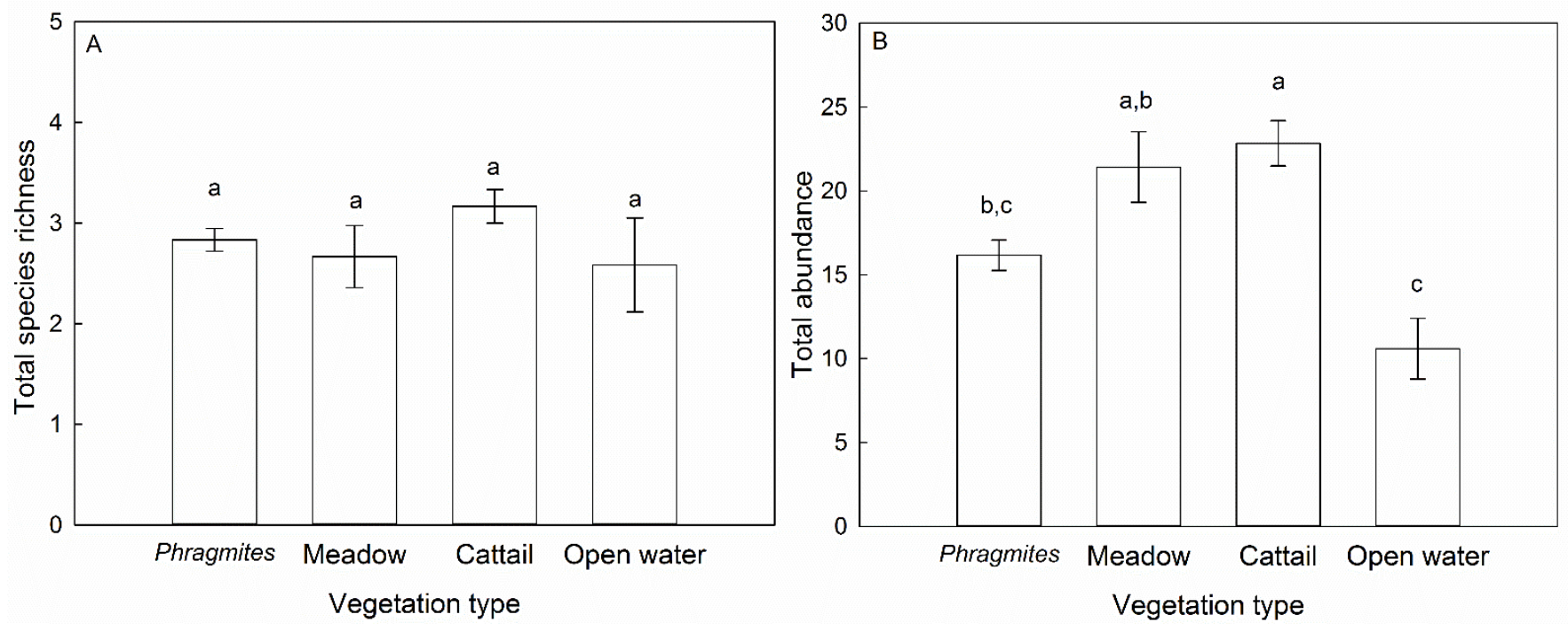

Figure 2-2. The four vegetation types exhibited no difference in total species richness $(p=0.272)$

(A), but total bird abundance was affected by vegetation type $(p<0.01)(B)$. Total abundance based on summed occurrences and total species richness based on summed number of species at 48 point count locations in Long Point, ON. Error bars represent standard error, lower case letters represent Tukey's HSD post-hoc comparison results. Bars with the same letter do not differ significantly. 

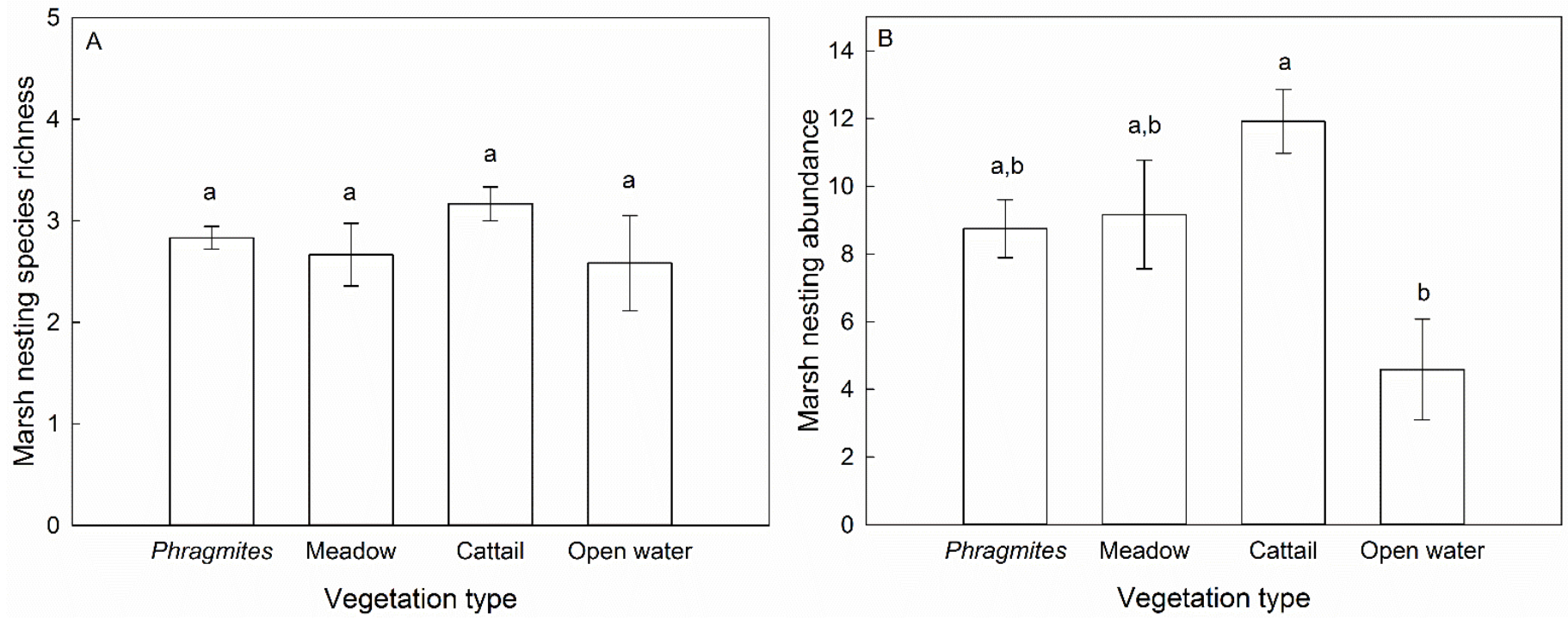

Figure 2-3. No difference in marsh-nesting bird richness among the four vegetation types $(\mathrm{p}=0.529)$ (A), while abundance is affected by vegetation type $(\mathrm{p}=0.002)(\mathrm{B})$. Marsh-nesting abundance based on summed marsh-nester occurrences and species richness based on summed number of marsh-nesting species at 48 point count locations in Long Point, ON. Error bars represent standard error, lower-case letters represent Tukey's HSD post-hoc comparison results. Bars with the same letter do not differ significantly 


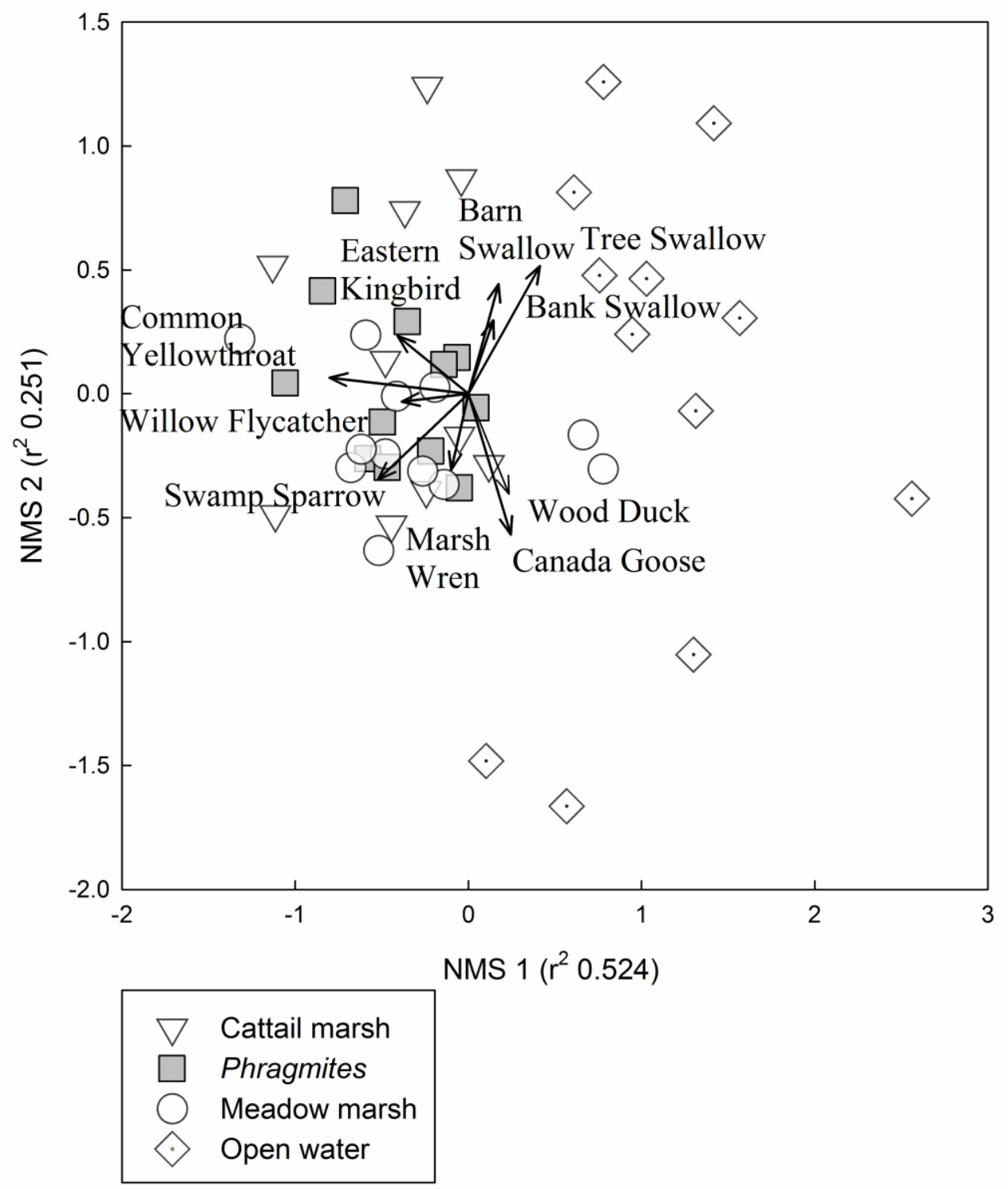

Figure 2-4. 2D NMS ordination solution of Bray-Curtis dissimilarity matrix calculated using bird species abundances with bird species vectors overlaid (final stress 18.54). In this joint plot, only species whose abundance was reasonably correlated with at least one ordination axis are depicted as vectors. Symbology of points represents the four habitat types considered: Phragmites australis, cattail marsh, meadow marsh, and open-water 


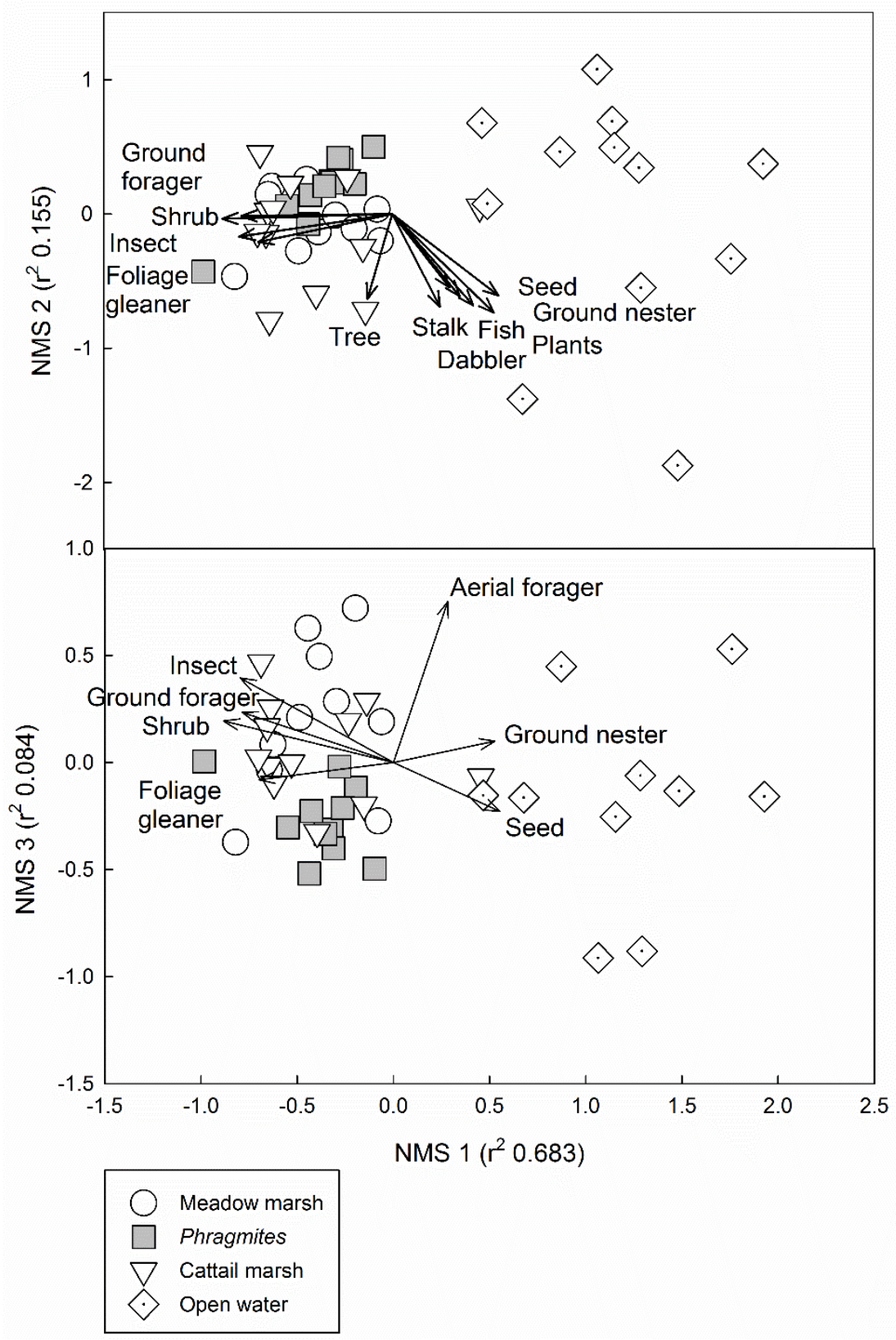

Figure 2-5: 3D NMS ordination solution of Bray-Curtis dissimilarity matrix calculated using bird species abundances with bird functional trait vectors overlaid (stress 9.59). Joint plots depict site ordination scores overlaid with bird functional traits correlated with each site. Symbology of points represents the four habitat types considered: Phragmites australis, cattail marsh, meadow marsh, and open-water. 
Table 2-1. Vegetation and environmental characterization of the four studied vegetation types in Long Point, ON, based on twelve point count locations in each vegetation type. Simpson's diversity index calculated as $1 / \sum(n / N)^{2}$

\begin{tabular}{|c|c|c|c|c|}
\hline $\begin{array}{l}\text { Vegetation } \\
\text { Type }\end{array}$ & $\begin{array}{l}\text { Dominant species } \\
\text { (relative cover \%) }\end{array}$ & $\begin{array}{l}\text { Simpson's } \\
\text { Diversity } \\
\text { Index }\end{array}$ & $\begin{array}{l}\text { Average water } \\
\text { depth }(\mathrm{cm}) \pm \\
\text { SD }\end{array}$ & $\begin{array}{l}\text { Average canopy } \\
\text { height }(\mathrm{cm}) \pm \mathrm{SD}\end{array}$ \\
\hline $\begin{array}{l}\text { Meadow } \\
\text { marsh }\end{array}$ & $\begin{array}{l}\text { Calamagrostis } \\
\text { canadensis }(49.18)\end{array}$ & 3.176 & $19 \mathrm{~cm} \pm 12 \mathrm{~cm}$ & $93 \mathrm{~cm} \pm 16 \mathrm{~cm}$ \\
\hline Cattail marsh & Typha spp. (77.02) & 1.768 & $32 \mathrm{~cm} \pm 7 \mathrm{~cm}$ & $247 \mathrm{~cm} \pm 35 \mathrm{~cm}$ \\
\hline $\begin{array}{l}\text { Open-water } \\
\text { marsh }\end{array}$ & $\begin{array}{l}\text { Nymphaea odorata } \\
(24.16)\end{array}$ & 1.464 & $>1 \mathrm{~m}$ & $\mathrm{n} / \mathrm{a}$ \\
\hline P. australis & $\begin{array}{l}\text { Phragmites australis } \\
(72.00)\end{array}$ & 1.756 & $27 \mathrm{~cm} \pm 14 \mathrm{~cm}$ & $302 \mathrm{~cm} \pm 35 \mathrm{~cm}$ \\
\hline
\end{tabular}


Table 2-2. Total bird abundance and marsh-nesting bird abundance were influenced by vegetation type, whereas total and marsh-nesting species richness was not influenced by any of the factors. Two-factor ANOVA results compared bird abundance and richness among three vegetation types (Phragmites australis, cattail marsh, meadow marsh); one-way ANOVA results compared bird abundance and richness between four (P. australis, cattail marsh, meadow marsh, open-water)

\begin{tabular}{|c|c|c|c|c|c|c|}
\hline \multirow[t]{2}{*}{ Response } & \multicolumn{3}{|c|}{ Two-factor ANOVA } & \multicolumn{3}{|c|}{$\begin{array}{l}\text { One-factor ANOVA (with open- } \\
\text { water) }\end{array}$} \\
\hline & $F$ & $\begin{array}{l}\text { Degrees } \\
\text { freedom }\end{array}$ & $p$ & $F$ & $\begin{array}{l}\text { Degrees } \\
\text { freedom }\end{array}$ & $p$ \\
\hline Total Abundance & 4.94 & 2,30 & 0.014 & 12.05 & 3,44 & $6.94 \mathrm{e}^{-6}$ \\
\hline $\begin{array}{l}\text { Total Species } \\
\text { Richness }\end{array}$ & 1.74 & 2,30 & 0.192 & 1.35 & 3,44 & 0.272 \\
\hline $\begin{array}{l}\text { Marsh-nesting } \\
\text { Abundance }\end{array}$ & 0.66 & 2,30 & 0.523 & 5.73 & 3,44 & 0.002 \\
\hline $\begin{array}{l}\text { Marsh-nesting } \\
\text { Species Richness }\end{array}$ & 0.87 & 2,30 & 0.431 & 0.75 & 3,44 & 0.529 \\
\hline
\end{tabular}


Table 2-3. perMANOVA contrasting species composition and functional traits among the three vegetation types possessing edge and interior point count locations (Phragmites australis, cattail marsh, meadow marsh). Each of the three vegetation types supported distinct bird communities. Bird functional traits in P. australis were significantly different from those in cattail and meadow marsh; however, functional traits in cattail and meadow marsh were similar.

\begin{tabular}{llclc}
\hline perMANOVA & \multicolumn{2}{l}{ Species composition } & \multicolumn{2}{l}{ Functional traits } \\
\hline Vegetation types & \multicolumn{2}{l}{$F_{2,35}=2.69, p<0.001$} & \multicolumn{2}{l}{$F_{2,35}=3.15, p<0.001$} \\
Post-hoc comparison & $T$ & $p$ & $T$ & $p$ \\
Cattail marsh x P. australis & 1.64 & 0.006 & 1.97 & 0.002 \\
Cattail marsh x meadow marsh & 1.50 & 0.022 & 1.25 & 0.133 \\
$P$. australis x meadow marsh & 1.81 & $<0.001$ & 2.22 & $<0.001$ \\
\hline
\end{tabular}


Table 2-4. MRPP results comparing species composition and functional traits in all four vegetation types (Phragmites australis, cattail marsh, meadow marsh, open-water). Each vegetation type supports a distinct bird community; however, cattail and meadow marsh vegetation types support similar functional traits.

\begin{tabular}{|c|c|c|c|c|}
\hline \multirow[t]{2}{*}{ MRPP } & \multicolumn{2}{|c|}{ Species composition } & \multicolumn{2}{|c|}{ Functional traits } \\
\hline & $A$ & $p$ & $A$ & $p$ \\
\hline Vegetation type & 0.107 & $<0.001$ & 0.192 & $<0.001$ \\
\hline Cattail marsh $\mathrm{x}$ P. australis & 0.042 & 0.003 & 0.095 & $<0.001$ \\
\hline Cattail marsh $\mathrm{x}$ meadow marsh & 0.026 & 0.034 & 0.003 & 0.350 \\
\hline Cattail marsh $\mathrm{x}$ open water & 0.063 & $<0.001$ & 0.201 & $<0.001$ \\
\hline P. australis $\mathrm{x}$ meadow marsh & 0.054 & 0.001 & 0.085 & $<0.001$ \\
\hline P. australis $\mathrm{x}$ open-water & 0.134 & $<0.001$ & 0.244 & $<0.001$ \\
\hline Meadow marsh $\mathrm{x}$ open water & 0.108 & $<0.001$ & 0.129 & $<0.001$ \\
\hline
\end{tabular}


Table 2-5. Comparison of results into the effects of Phragmites australis invasion on birds in Long Point carried out during the breeding season in 2001-2002 (Meyer et al. 2010) and 2015 results. Two-way ANOVA results are presented for all 2015 vegetation type and locus, one-way ANOVA results presented for open-water vegetation type

\begin{tabular}{|c|c|c|c|}
\hline Response variable & Factor & 2015 results & 2001-2002 results \\
\hline \multirow[t]{3}{*}{ Total abundance } & $\begin{array}{l}\text { Vegetation type } \\
\text { (two-way ANOVA) }\end{array}$ & $\begin{array}{l}P . \text { australis lower, } \\
\text { significantly lower than } \\
\text { cattail marsh }(\mathrm{p}=0.014)\end{array}$ & $\begin{array}{l}\text { Highest in } P . \text { australis } \\
(\mathrm{p}=0.036)\end{array}$ \\
\hline & $\begin{array}{l}\text { Vegetation type } \\
\text { (one-way ANOVA) }\end{array}$ & $\begin{array}{l}\text { Open-water lowest } \\
(\mathrm{p}<0.001)\end{array}$ & Open-water not considered \\
\hline & Locus & $\begin{array}{l}\text { No significant effect } \\
(p=0.567)\end{array}$ & $\begin{array}{l}20 \% \text { higher in edge } \\
(p=0.083)\end{array}$ \\
\hline \multirow[t]{3}{*}{$\begin{array}{l}\text { Total species } \\
\text { richness }\end{array}$} & $\begin{array}{l}\text { Vegetation type } \\
\text { (two-way ANOVA) }\end{array}$ & $\begin{array}{l}\text { No significant effect } \\
(p=0.192)\end{array}$ & $\begin{array}{l}\text { Higher in } P . \text { australis }(\mathrm{p}= \\
0.006)\end{array}$ \\
\hline & $\begin{array}{l}\text { Vegetation type } \\
\text { (one-way ANOVA) }\end{array}$ & $\begin{array}{l}\text { No significant effect } \\
(p=0.272)\end{array}$ & Open-water not considered \\
\hline & Locus & $\begin{array}{l}\text { No significant effect } \\
(p=0.112)\end{array}$ & $\begin{array}{l}20 \% \text { higher in edge } \\
(p=0.001)\end{array}$ \\
\hline \multirow[t]{3}{*}{$\begin{array}{l}\text { Marsh-nesting } \\
\text { abundance }\end{array}$} & $\begin{array}{l}\text { Vegetation type } \\
\text { (two-way ANOVA) }\end{array}$ & $\begin{array}{l}\text { No significant effect } \\
(p=0.523)\end{array}$ & $\begin{array}{l}\text { Highest in meadow marsh } \\
(p=0.047)\end{array}$ \\
\hline & $\begin{array}{l}\text { Vegetation type } \\
\text { (one-way ANOVA) }\end{array}$ & $\begin{array}{l}\text { Lowest in open-water } \\
(p=0.002)\end{array}$ & Open-water not considered \\
\hline & Locus & $\begin{array}{l}\text { No significant effect } \\
(p=0.159)\end{array}$ & $\begin{array}{l}\text { Higher in edge } \\
(p=0.015)\end{array}$ \\
\hline \multirow[t]{3}{*}{$\begin{array}{l}\text { Marsh-nesting } \\
\text { species richness }\end{array}$} & $\begin{array}{l}\text { Vegetation type } \\
\text { (two-way ANOVA) }\end{array}$ & $\begin{array}{l}\text { No significant effect } \\
(p=0.431)\end{array}$ & $\begin{array}{l}\text { No significant effect } \\
(p>0.10)\end{array}$ \\
\hline & $\begin{array}{l}\text { Vegetation type } \\
\text { (one-way ANOVA) }\end{array}$ & $\begin{array}{l}\text { No significant effect } \\
(p=0.529)\end{array}$ & Open-water not considered \\
\hline & Locus & $\begin{array}{l}\text { No significant effect } \\
(p=0.387)\end{array}$ & $\begin{array}{l}\text { No significant effect } \\
(p>0.10)\end{array}$ \\
\hline
\end{tabular}




\subsection{Implications}

\subsection{Thesis overview}

Introduced Phragmites australis is aggressively colonizing the coastal marshes of Long Point, ON. These marshes comprise over $70 \%$ of the wetland habitat on the north shore of Lake Erie and provide habitat for a number of provincially significant birds, including at risk marshdependent species such as Black Tern (Chlidonias niger) and Least Bittern (Ixobrychus exilis). Many secretive, wetland-dependent species that rely on coastal marshes are in decline throughout the southern Great Lakes (Tozer, 2016). These declines have been attributed to urban development, decreases in wetland area, and - in the case Virginia Rail (Rallus limicola) - to the ongoing invasion by $P$. australis (Tozer, 2016). The invasion of Long Point by introduced $P$. australis raises concerns about the effects of invasion on bird communities, as Long Point represents a significant portion of the wetlands remaining on the north shore of Lake Erie.

Phragmites australis colonization can alter wetlands and compromise habitat that is essential for wetland-dependent bird species that require marshes for breeding and nesting. The tall, dense stands that $P$. australis produces can reduce floristic diversity (Keller, 2000), fill in open-water pools (Able et al., 2003), and restrict access for certain larger-bodied bird species (Benoit and Askins, 1999; Kessler et al., 2011). Within Long Point, where P. australis is replacing the historically dominant cattail and meadow marsh communities (Wilcox et al., 2003), this conversion results in more structural homogeneity as $P$. australis stands become denser and fillin canopy gaps as they age (Rooth et al., 2003).

The population of introduced $P$. australis in Long Point grew exponentially in Long Point during the late 1990s, when low water levels facilitated its spread (Wilcox et al., 2003). This rapid expansion motivated research into the effects of the $P$. australis invasion on bird 
communities in 2001-2002. Comparing birds in P. australis with the meadow marsh and cattail marsh habitats that it was replacing, research carried out during this rapid expansion stage of the invasion found higher total abundance and species richness of birds in P. australis habitat, especially around its edges (Meyer et al., 2010). Marsh-nesting birds specifically had lower abundances in $P$. australis however, in general this earlier research concluded that $P$. australis invasion is benign for birds in Long Point. The goal of my thesis was to evaluate the changes in bird occupancy within Long Point's marshes after years of unmitigated P. australis invasion progress. My work was designed to build on the Meyer et al. (2010) study, which took place over ten years ago.

\subsection{Research Conclusions}

In my $1^{\text {st }}$ chapter I established the context of $P$. australis invasion in wetlands, and the potential deleterious effects of long-term invasion. Further, I conveyed the importance of Long Point, ON as essential coastal marsh habitat for numerous bird species, including marshdependent species in decline throughout Lake Erie and Ontario. I also set the context for my second chapter by discussing current disagreements in the literature regarding $P$. australis impacts on birds within invaded wetlands.

In my $2^{\text {nd }}$ second chapter I built on work by Meyer et al. (2010) carried out during the early stages of invasion $(2001-2002)$ in Long Point, Ontario. I surveyed birds in patches of $P$. australis, meadow marsh, and cattail marsh within Long Point's Big Creek National Wildlife Area, Crown Marsh, and Long Point Provincial Park. Additionally, because of the ability of $P$. australis to fill-in open-water pools, I added an evaluation of open-water habitat to the study to fully capture the potential implications of invasion on the different marsh types. In keeping with 
the Meyer et al. (2010) study design, I assessed the differences in abundance and species richness among all four vegetation types for both total birds and marsh-nesting birds. I sought to determine if marsh-nesting birds were less diverse and abundant in P. australis, if overall bird diversity was lower in $P$. australis patches and if the birds observed in $P$. australis were a subset of birds using meadow marsh and cattail marsh habitat. I found that $P$. australis did not have a significant effect on total bird species richness, or on marsh-nesting bird species richness or abundance, but that birds present in P. australis, with the exception of Yellow Warbler (Dendroica petechia), were present in higher abundances in other habitat types. In keeping with the historical Meyer et al. (2010) study, I also assessed bird use of the edges of patches (within 50 meters of another vegetation type), hypothesizing that abundance and species richness would be higher in edge stands. However, in 2015 there no longer appeared to be a significant effect of stand location on bird abundance or species richness.

Since invasion may have implications for birds that cannot be captured with simple counts of individuals or species, I also evaluated the species composition of bird communities and bird functional traits (e.g. diet, foraging behaviour, nesting preferences). I sought to determine if the bird species and functional traits of birds supported by $P$. australis were different than other vegetation types, and hypothesized that $P$. australis would support birds that consume insects and nest in shrubs. In Long Point in 2015, P. australis did appear to support birds that consumed insects, preferentially nested in shrub habitat, and foraged as foliage gleaners or ground foragers, while birds that hunted via stalking or dabbling, consumed fish, seeds, or plants, and nested on the ground associated with other vegetation types. 
In addition to my focus on birds within the marsh, I also characterized the vegetation growing at each point count location, to help evaluate the relationship between vegetation and bird occupancy more thoroughly.

\subsection{Implications and Significance}

Currently, there is little agreement in the literature regarding whether $P$. australis invasion affects bird communities. My research directly contributes to the improved understanding of the effects of $P$. australis invasion, as it is the only study to compare bird occupancy during the latter stage of $P$. australis invasion with data collected during the early stages of invasion, namely the study by Meyer et al. (2010). Further, my work incorporates a measure of community composition and functional traits to detect subtler effects of invasion than simple changes in species richness and total abundance of birds. My results indicate that community composition must be considered when evaluating the effects of biological invasion.

My findings suggest that the full effects of $P$. australis invasion exhibit a lag time. While the invasion in Long Point appeared relatively benign, or even beneficial for birds in the early stages of invasion (Meyer et al., 2010) when it was expanding exponentially (Wilcox et al., 2003), by 2015 the invasion had seriously altered bird communities. Marsh-nesting species of concern are now excluded from $P$. australis habitat and total bird abundances are lower than found in the historically dominant cattail and meadow marshes. Further, there is no longer any evidence of beneficial edge effects at the margins of $P$. australis patches. These changes are likely due to the

progression of $P$. australis invasion. Phragmites australis often colonizes new areas by establishment via seed or propagule, and then radiates out from a center point by vegetative reproduction, using stolons, rhizomes and even regrowth from knocked over stems (Kettenring et 
al., 2016). The leading edges of expanding patches are less dense, especially in younger stands, but begin to fill in and produce more above-ground biomass and litter as they age (Rooth et al., 2003). In 2001-2002, when the original study found more individuals and species of birds occupying the margins of $P$. australis patches, the sparse stems at the edge of $P$. australis patches may have provided shelter or roosts to birds. Thirteen years later, now that $P$. australis comprises the majority of marsh habitat in our study area in Long Point (Appendix 2), the loss of more diverse cattail, meadow and open-water marsh habitat outweighs any benefits of additional refuge and roosting habitat. Further, the high densities of $P$. australis stems likely makes established $P$. australis patches much less useable for birds: e.g., we observed stem densities of over 70 live stems per $\mathrm{m}^{2}$ and over 190 stems per $\mathrm{m}^{2}$ when considering both live and dead stems (Rooney unpublished data). My results suggest that it takes years or even decades for the deleterious effects of $P$. australis invasion to become apparent. This realization helps explain why some studies report finding a significant negative effect of invasion on avifauna, whereas others report negligible effects or even benefits to the bird community: these studies are most likely taking place during different phases of the $P$. australis invasion.

The evaluation of bird species community composition and functional traits also captures significant changes in bird communities between invaded and uninvaded marsh habitat. Examining the relative abundance of bird species is especially pertinent when seeking to capture the effects of $P$. australis invasion on marsh-nesting species of concern that rely on coastal marshes. By analyzing the relative abundance of different bird species and their functional traits, I was able to identify and describe subtler changes occurring in Long Point's avifauna. Although rare throughout Long Point, marsh-nesting species of conservation concern were never observed in $P$. australis, and species with functional traits such as ground nesting were more abundant in meadow 
and cattail marsh. This exemplifies the need to consider community composition, as a shift from habitat specialists to more generalist species goes unnoticed in simple measures of species richness. Additionally, examining community composition and the functional traits of birds provides a more ecologically meaningful understanding of the changes in bird communities that are resulting from $P$. australis invasion.

These findings are relevant to researchers working with P. australis, or wetland managers working in the Great Lakes where $P$. australis invasion is a serious problem, as it threatens biodiversity and species at risk. Furthermore, with climate change and current distribution, $P$. australis is expected to expand its range throughout the Great Lakes (Catling and Mitrow, 2011; Mazur et al., 2014; Tougas-Tellier et al., 2015). This means a thorough understanding of the impacts of invasion on bird communities, and of the tools used to measure changes in biological communities, is timely and relevant to anyone working with $P$. australis. Finally, this work advances our understanding of long-term invasions and also emphasizes the importance of timely, effective control measures to preserve marsh habitat.

\subsection{Future Work}

More direct measurements of bird use within invaded and uninvaded habitats is the next step in understanding how the P. australis invasion is affecting bird use of the Long Point marshes. A measure of nesting frequency and nest success would provide a more in-depth quantification of bird use, whereas work to date has focused simply on bird occupancy. This could also provide insight into the quality of $P$. australis habitat, determining if it presents a viable option for breeding and nesting birds, or an ecological trap and population sink habitat (Pulliam, 1988; Robertson and Hutto, 2006). The work presented in this thesis can help inform future research into the effects of 
invasion on bird use, as my thesis highlights which species are abundant in P. australis and which were never detected using it.

I also recommend, as suggested by Whyte et al. (2015), that future research examining the ecological effects of $P$. australis invasion seek to characterize $P$. australis habitat more thoroughly, as this would facilitate inter-study comparisons. Approximate stand or invasion age, stem density, canopy height, dominant vegetation species and relative cover within the study system are all variables that could be reported, as they provide relevant detail when interpreting results.

This study is, to my knowledge, the first to repeat an evaluation of bird communities in the same geographical location after many years of invasion progression. This provides a possible explanation for disagreements in the current literature over the severity of $P$. australis invasion effects on bird communities, and fills in knowledge gaps regarding the effects when invasion progresses unimpeded. Further, it fills gaps in the literature regarding the effects of $P$. australis invasion on species composition and functional traits of birds, providing an ecologically relevant measure of effects. 


\section{References}

Able, K.W., Hagan, S.M., 2003. Impact of common reed, Phragmites australis, on essential fish habitat: Influence on reproduction, embryological development, and larval abundance of mummichog (Fundulus heteroclitus). Estuaries 26, 40-50.

Able, K.W., Hagan, S.M., 2000. Effects of Common Reed (Phragmites australis) invasion on marsh surface macrofauna: Response of fishes and decapod crustaceans. Estuaries 23, 633646.

Able, K.W., Hagan, S.M., Brown, S.A., 2003. Mechanisms of marsh habitat alteration due to Phragmites: Response of young-of-the-year mummichog (Fundulus heteroclitus) to treatment for Phragmites removal. Estuaries 26, 484-494.

Ágoston-Szabó, E., Dinka, M., 2008. Decomposition of Typha angustifolia and Phragmites australis in the littoral zone of a shallow lake. Biologia (Bratisl). 63, 1104-1110.

Ailstock, M.S., Norman, C.M., Bushmann, P.J., 2001. Common reed Phragmites australis: Control and effects upon biodiversity in freshwater nontidal wetlands. Restor. Ecol. 9, 4959.

Amsberry, L., Baker, M.A., Ewanchuk, P.J., Bertness, M.D., 2000. Clonal integration and the expansion of Phragmites australis. Ecol. Appl. 10, 1110-1118.

Anderson, M.J., 2001. A new method for non-parametric multivariate analysis of variance. Austral Ecol. 26, 32-46.

Anderson, M.J., Walsh, D.C.I., 2013. PERMANOVA, ANOSIM, and the Mantel test in the face of heterogeneous dispersions: What null hypothesis are you testing? Ecol. Monogr. 83, $557-574$.

Angradi, T.R., Hagan, S.M., Able, K.W., 2001. Vegetation type and the intertidal macroinvertebrate fauna of a brackish marsh: Phragmites vs. Spartina. Wetlands 21, 75-92.

Armstrong, J., Afreen-Zobayed, F., Blyth, S., Armstrong, W., 1999. Phragmites australis: effects of shoot submergence on seedling growth and survival and radial oxygen loss from roots. Aquat. Bot. 64, 275-289. 
Baldwin, A.H., Kettenring, K.M., Whigham, D.F., 2010. Seed banks of Phragmites australisdominated brackish wetlands: Relationships to seed viability, inundation, and land cover. Aquat. Bot. 93, 163-169.

Ball, H., Jalava, J., King, T., Maynard, L., Potter, B., Pulfer, T., 2003. The Ontario Great Lakes Coastal Weltand Atlas: A summary of information (1983-1997). Environment Canada 49.

Bart, D., Hartman, J.M., 2003. The role of large rhizome dispersal and low salinity windows in the establishment of common reed, Phragmites australis, in Salt Marshes: New links to human activities. Estuaries 26, 436-443.

Belzile, F., Labbé, J., LeBlanc, M.-C., Lavoie, C., 2010. Seeds contribute strongly to the spread of the invasive genotype of the common reed (Phragmites australis). Biol. Invasions 12, $2243-2250$.

Benoit, L.K., Askins, R., 2002. Relationship between habitat area and the distribution of tidal marsh birds. Wilson Bull. 114, 314-323.

Benoit, L.K., Askins, R.A., 1999. Impact of the spread of Phragmites on the distribtion of birds in Connecticut tidal marshes. Wetlands 19, 194-208.

Bhattarai, G.P., Allen, W.J., Cronin, J.T., Kiviat, E., Meyerson, L.A., 2016. Response to Blossey and Casagrande: ecological and evolutionary processes make host specificity at the subspecies level exceedingly unlikely. Biol. Invasions 18, 2757-2758.

Bird Studies Canada, 2016. Long Point Bird Observatory 2015 Program Report. Port Rowan, $\mathrm{ON}$.

Bird Studies Canada, 2009. Marsh Monitoring Program Participant's Handbook, Bird Studies Canada in Cooperation with Environment Canada and the. U.S. Environmental Protection Agency, Port Rowan, ON.

Blossey, B., Casagrande, R.A., 2016a. Biological control of invasive Phragmites may safeguard native Phragmites and increase wetland conservation values. Biol. Invasions 18, 27532755.

Blossey, B., Casagrande, R.A., 2016b. Response to Bhattarai et al.: Trait differences between 
native and introduced genotypes results in subspecies level specificity in select Phragmites herbivores. Biol. Invasions 18, 2759-2760.

Blossey, B., Notzold, R., 1995. Evolution of increased competitive ability in invasive nonindigenous plants: A hypothesis. J. Ecol. 83, 887-889.

Boar, R.R., 1996. Temporal variations in the nitrogen content of Phragmites australis (Cav.) Trin. ex Steud. from a shallow fertile lake. Aquat. Bot. 55, 171-181.

Bray, J.R., Curtis, J.T., 1957. An ordination of the upland forest communities of Southern Wisconsin. Ecol. Monogr. 27, 325-349.

Brisson, J., Blois, S. De, Lavoie, C., 2010. Roadside as Invasion Pathway for Common Reed (Phragmites australis). Invasive Plant Sci. Manag. 3, 506-514.

Cadotte, M.W., McMahon, S.M., Fukami, T., 2006. Conceptual ecology and invasion biology: Reciprocal approaches to nature, Volume 1. ed, Springer Series in Invasion Ecology. Springer, Dordrecht, The Netherlands.

Catling, P.. P.M., Mitrow, G., 2011. The recent spread and potential distribution of Phragmites australis subsp. australis in Canada. Can. Field-Naturalist 125, 95-104.

Chambers, R.M., Meyerson, L.A., Saltonstall, K., 1999. Expansion of Phragmites australis into tidal wetlands of North America. Aquat. Bot. 64, 261-273.

Chin, A.T.M., Tozer, D.C., Fraser, G.S., 2014. Hydrology influences generalist-specialist birdbased indices of biotic integrity in Great Lakes coastal wetlands. J. Great Lakes Res. 40, $281-287$.

Conway, C.J., 1995. Virginia Rail (Rallus limicola), in: Rodewald, P.G. (Ed.), The Birds of North America Online. Cornell Lab of Ornithology, Ithaca. (https://birdsna.org/SpeciesAccount/bna/species/virrai)

Davis, M.A., 2009. Invasion Biology. Oxford University Press Inc., New York. 1-193

Ducks Unlimited Canada, 2010. Southern Ontario Wetland Conversion Analysis. Barrie, ON.

Engloner, A.I., Papp, M., 2006. Vertical differences in Phragmites australis culm anatomy along a water depth gradient. Aquat. Bot. 85, 137-146. 
Fell, P.E., Warren, R.S., Light, J.K., Rawson, R.L., Fairley, S.M., 2003. Comparison of fish and macroinvertebrates use of Typha angustifolia, Phragmites australis, and treated Phragmites marshes along the Lower Connecticut River. Estuaries 26, 534-551.

Fell, P.E., Weissbach, S.P., Jones, D.A., Fallon, M.A., Zeppieri, J.A., Faison, E.K., Lennon, K.W., Newberry, K.J., Reddington, K., 1998. Does invasion of oligohaline tidal marshes by reed grass, Phragmites australis (Cav.) Trin. ex Steud., affect the availability of prey resources for the mummichog, Fundulus heteroclitus L.? J. Exp. Mar. Bio. Ecol. 222, 5977.

Gagnon Lupien, N., Gauthier, G., Lavoie, C., 2015. Effect of the invasive common reed on the abundance, richness and diversity of birds in freshwater marshes. Anim. Conserv. 18, $32-$ 43.

Gronewold, A.D., Clites, A.H., Smith, J.P., Hunter, T.S., 2013. A dynamic graphical interface for visualizing projected, measured, and reconstructed surface water elevations on the earth's largest lakes. Environ. Model. Softw. 49, 34-39.

Guzy, M.J., Ritchison, G., 1999. Common Yellowthroat (Geothlypis trichas), in: Rodewald, P.G. (Ed.). The Birds of North America Online, Cornell Lab of Ornithology, Ithaca (https://birdsna.org/Species-Account/bna/species/comyel)

Hara, T., van Der Toorn, J., Mook, J.., 1993. Growth dynamics and size structure of shoots of Phragmites australis, a clonal plant. J. Ecol. 81, 47-60.

Haslam, S.M., 1972. Phragmites communis Trin. (Arundo Phragmites L. Phragmites australis (Cav.) Trin. ex Steudal). J. Ecol. 60, 585-610.

Haslam, S.M., 1971a. The development and establishment of young plants of Phragmites communis Trin. Ann. Bot. 35, 1059-1072.

Haslam, S.M., 1971b. Community Regulation in Phragmites communis Trin.: II. Mixed Stands. J. Ecol. 59, 75-88.

Haslam, S.M., 1970a. The development of the annual population in Phragmites communis Trin. Ann. Bot. 34, 571-591. 
Haslam, S.M., 1970b. Variation of population type in Phragmites communis Trin. Ann. Bot. 34, 147-158.

Haslam, S.M., 1969. Stem types of Phragmites communis Trin. Ann. Bot. 33, 127-132.

Hill, M.O., 1973. Diversity and evenness: a unifying notion and its consequences. Ecology 54, 427-432.

Hirtreiter, J.N., Potts, D.L., 2012. Canopy structure, photosynthetic capacity and nitrogen distribution in adjacent mixed and monospecific stands of Phragmites australis and Typha latifolia. Plant Ecol. 213, 821-829.

Holdredge, C., Bertness, M.D., 2011. Litter legacy increases the competitive advantage of invasive Phragmites australis in New England wetlands. Biol. Invasions 13, 423-433.

Holomuzki, J.R., Klarer, D.M., 2010. Invasive reed effects on benthic community structure in Lake Erie coastal marshes. Wetl. Ecol. Manag. 18, 219-231.

Hudon, C., Gagnon, P., Jean, M., 2005. Hydrological factors controlling the spread of common reed (Phragmites australis) in the St. Lawrence River (Québec, Canada). Ecoscience 12, 347-357.

Hughes, A.R., Schenck, F.R., Bloomberg, J., Hanley, T.C., Feng, D., Gouhier, T.C., Beighley, R.E., Kimbro, D.L., 2016. Biogeographic gradients in ecosystem processes of the invasive ecosystem engineer Phragmites australis. Biol. Invasions 18, 2577-2595. doi:10.1007/s10530-016-1143-0

Ishii, J., Kadono, Y., 2002. Factors influencing seed production of Phragmites australis. Aquat. Bot. 72, 129-141. doi:10.1016/S0304-3770(01)00218-2

Jodoin, Y., Lavoie, C., Villeneuve, P., Theriault, M., Beaulieu, J., Belzile, F., 2008. Highways as corridors and habitats for the invasive common reed Phragmites australis in Quebec, Canada. J. Appl. Ecol. 45, 459-466.

Juneau, K.J., Tarasoff, C.S., 2013. The seasonality of survival and subsequent growth of common reed (Phragmites australis) rhizome fragments. Invasive Plant Sci. Manag. 6, 7986. 
Keddy, P.A., Reznicek, A.A., 1986. Great Lakes vegetation dynamics: The role of fluctuating water levels and buried seeds. J. Great Lakes Res. 12, 25-36.

Keller, B.E.M., 2000. Plant diversity in Lythrum, Phragmites, and Typha, Massachusetts, U.S.A. Wetl. Ecol. Manag. 8, 391-401.

Kessler, A.C., Merchant, J.W., Allen, C.R., Shultz, S.D., 2011. Impacts of invasive plants on Sandhill Crane (Grus canadensis) roosting habitat. Invasive Plant Sci. Manag. 4, 369-377.

Kettenring, K.M., de Blois, S., Hauber, D.P., 2012. Moving from a regional to a continental perspective of Phragmites australis invasion in North America. AoB Plants 18.

Kettenring, K.M., Mock, K.E., 2012. Genetic diversity, reproductive mode, and dispersal differ between the cryptic invader, Phragmites australis, and its native conspecific. Biol. Invasions 14, 2489-2504.

Kettenring, K.M., Mock, K.E., Zaman, B., McKee, M., 2016. Life on the edge: reproductive mode and rate of invasive Phragmites australis patch expansion. Biol. Invasions 18, 24752495.

Kirk, H., Paul, J., Straka, J., Freeland, J.R., 2011. Long-distance dispersal and high genetic diversity are implicated in the invasive spread of the common reed, Phragmites australis (Poaceae), in northeastern North America. Am. J. Bot. 98, 1180-1190.

Knapton, R.W., Petrie, S. a., 1999. Changes in distribution and abundance of submerged macrophytes in the inner bay at Long Point, Lake Erie: Implications for foraging waterfowl. J. Great Lakes Res. 25, 783-798.

Konisky, R.A., Burdick, D.M., 2004. Effects of stressors on invasive and halophytic plants of New England salt marshes: A framework for predicting response to tidal restoration. Wetlands 24, 434-447.

Kroodsma, D.E., Verner, J., 2014. Marsh Wren (Cistothorus palustris), in: Rodewald, P.G. (Ed.). The Birds of North America Online, Cornell Lab of Ornithology, Ithaca (https://birdsna.org/Species-Account/bna/species/marwre)

Kuussaari, M., Bommarco, R., Heikkinen, R.K., Helm, A., Krauss, J., Lindborg, R., Öckinger, 
E., Pärtel, M., Pino, J., Rodà, F., Stefanescu, C., Teder, T., Zobel, M., Steffan-Dewenter, I., 2009. Extinction debt: a challenge for biodiversity conservation. Trends Ecol. Evol. 24, $564-571$.

Lambert, A.M., Casagrande, R.A., 2007. Susceptibility of native and non-native common reed to the non-native Mealy Plum Aphid (Homoptera: Aphididae) in North America. Environ. Entomol. 36, 451-457.

Lambert, A.M., Saltonstall, K., Long, R., Dudley, T.L., 2016. Biogeography of Phragmites australis lineages in the southwestern United States. Biol. Invasions 18, 2597-2617.

Lambert, A.M., Winiarski, K., Casagrande, R.A., 2007. Distribution and impact of exotic gall flies (Lipara sp.) on native and exotic Phragmites australis. Aquat. Bot. 86, 163-170.

Lambertini, C., 2016. Heteroplasmy due to chloroplast paternal leakage: another insight into Phragmites haplotypic diversity in North America. Biol. Invasions 18, 2443-2455.

Lathrop, R.G., Windham, L., Montesano, P., 2003. Does Phragmites expansion alter the structure and function of marsh landscapes? Patterns and processes revisited. Estuaries 26, $423-435$.

Lavoie, C., Jean, M., Delisle, F., Létourneau, G., 2003. Exotic plant species of the St. Lawrence River wetlands: a spatial and historical analysis. J. Biogeogr. 30, 537-549.

League, M.T., Colbert, E.P., Seliskar, D.M., Gallagher, J.L., 2006. Rhizome growth dynamics of native and exotic haplotypes of Phragmites australis (Common Reed). Estuaries and Coasts 29, 269-276.

Leishman, M.R., Thomson, V.P., 2005. Experimental evidence for the effects of additional water, nutrients and physical disturbance on invasive plants in low fertility Hawkesbury Sandstone soils, Sydney, Australia. J. Ecol. 93, 38-49.

Lelong, B., Lavoie, C., Jodoin, Y., Belzile, F., 2007. Expansion pathways of the exotic common reed (Phragmites australis): A historical and genetic analysis. Divers. Distrib. 13, 430-437.

Lenssen, J.P.M., Menting, F.B.J., Van der Putten, W.H., Blom, C.W.P.M., 2000. Variation in species composition and species richness within Phragmites australis dominated riparian 
zones. Plant Ecol. 147, 137-146.

Lockwood, J.L., Cassey, P., Blackburn, T., 2005. The role of propagule pressure in explaining species invasions. Trends Ecol. Evol. 20, 223-228.

Lowther, P., Poole, A.F., Gibbs, J.P., Melvin, S., Reid, F.A., 2009. American Bittern (Botaurus lentiginosus), in: Rodewald, P.G. (Ed.). The Birds of North America Online, Cornell Lab of Ornithology, Ithaca (https://birdsna.org/Species-Account/bna/species/amebit)

Lowther, P.E., Celada, C., Klein, N.K., Rimmer, C.C., Spector, D.A., 1999. Yellow Warbler (Setophaga petechia), in: Rodewald, P.G. (Ed.). The Birds of North America Online, Cornell Lab of Ornithology, Ithaca (https://birdsna.org/SpeciesAccount/bna/species/yelwar)

Mack, R.., Simberloff, D., Lonsdale, W.M., Evans, H., Clout, M., Bazzaz, F.A., 2000. Biotic Invasions: Causes, Epidemiology, Global Consequences, and Control Richard. Ecol. Appl. 10, 689-710.

Maheu-Giroux, M., de Blois, S., 2007. Landscape ecology of Phragmites australis invasion in networks of linear wetlands. Landsc. Ecol. 22, 285-301.

Maheu-Giroux, M., de Blois, S., 2005. Mapping the invasive species Phragmites australis in linear wetland corridors. Aquat. Bot. 83, 310-320.

Mal, T.K., Narine, L., 2004. The biology of Canadian weeds. 129. Phragmites australis (Cav.) Trin. ex Steud. Can. J. Plant Sci. 84, 365-396.

Marcaccio, J.V., Chow-Fraser, P., 2016. Remote sensing of Phragmites and wetland vegetation in the Long Point basin, in: Long Point World Biosphere 4th Research and Conservation Conference. Hamilton, ON.

Mazur, M.L.C., Kowalski, K.P., Galbraith, D., 2014. Assessment of suitable habitat for Phragmites australis (common reed) in the Great Lakes coastal zone. Aquat. Invasions 9, $1-19$.

McCormick, M.K., Brooks, H.E.A., Whigham, D.F., 2016. Microsatellite analysis to estimate realized dispersal distance in Phragmites australis. Biol. Invasions 18, 2497-2504. 
McCune, B., Grace, J.B., 2002. Analysis of Ecological Communities. MjM Software Design, Gleneden Beach, Oregon.

McCune, B., Mefford, M.J., 2011. PC-ORD. Multivariate Analysis of Ecological Data. Version 6. MjM Software, Gleneden Beach, Oregon, U.S.A.

Melvin, S.M., Gibbs, J.P., 2012. Sora (Porzana carolina), in: Rodewald, P.G. (Ed.). The Birds of North America Online, Cornell Lab of Ornithology, Ithaca (https://birdsna.org/SpeciesAccount/bna/species/sora)

Meyer, S.W., 2003. Comparative use of Phragmites australis and other habitats by birds, amphibians, and small mammals at Long Point, Ontario. MSc Thesis 146.

Meyer, S.W., Badzinski, S.S., Petrie, S.A., Ankney, C.D., 2010. Seasonal abundance and species richness of birds in common reed habitats in Lake Erie. J. Wildl. Manage. 74, 1559-1567. doi:10.2193/2008-467

Meyerson, L.A., Lambertini, C., McCormick, M.K., Whigham, D.F., 2012. Hybridization of common reed in North America? The answer is blowing in the wind. AoB Plants 9.

Meyerson, L.A., Saltonstall, K., Windham, L., Kiviat, E., Findlay, S., 2000. A comparison of Phragmites australis in freshwater and brackish marsh environments in North America. Wetl. Ecol. Manag. 8, 89-103.

Meyerson, L. A., Cronin, J.T., 2013. Evidence for multiple introductions of Phragmites australis to North America: detection of a new non-native haplotype. Biol. Invasions 15, 2605-2608.

Minchinton, T.E., 2002. Precipitation during El Nino correlates with increasing spread of Phragmites australis in New England, USA, coastal marshes. Mar. Ecol. Prog. Ser. 242, 305-309. doi:10.3354/meps242305

Minchinton, T.E., Bertness, M.D., 2003. Disturbance-mediated competition and the spread of Phragmites australis in a coastal marsh. Ecol. Appl. 13, 1400-1416.

Minchinton, T.E., Simpson, J.C., Bertness, M.D., 2006. Mechanisms of exclusion of native coastal marsh plants by an invasive grass. J. Ecol. 94, 342-354. 
Moore, G.E., Burdick, D.M., Peter, C.R., Keirstead, D.R., 2012. Belowground biomass of Phragmites australis in coastal marshes. Northeast. Nat. 19, 611-626.

Mowbray, T.B., 1997. Swamp Sparrow (Melospiza georgiana), in: Rodewald, P.G. (Ed.). The Birds of North America Online, Cornell Lab of Ornithology, Ithaca (https://birdsna.org/Species-Account/bna/species/swaspa)

Mozdzer, T.J., Caplan, J.S., Hager, R.N., Proffitt, C.E., Meyerson, L.A., 2016. Contrasting trait responses to latitudinal climate variation in two lineages of an invasive grass. Biol. Invasions 18, 2649-2660.

Mozdzer, T.J., Zieman, J.C., 2010. Ecophysiological differences between genetic lineages facilitate the invasion of non-native Phragmites australis in North American Atlantic coast wetlands. J. Ecol. 98, 451-458.

Okun, N., Mehner, T., 2005. Distribution and feeding of juvenile fish on invertebrates in littoral reed (Phragmites) stands. Ecol. Freshw. Fish 14, 139-149.

Park, M.G., Blossey, B., 2008. Importance of plant traits and herbivory for invasiveness of Phragmites australis (Poaceae). Am. J. Bot. 95, 1557-1568.

Paxton, B.J., 2006. Potential impact of common reed expansion on threatened high-marsh bird communities on the seaside: Assessment of Phragmites invasion of high marsh habitats, Center for Conservation Biology Technical Report Series, CCBTR-06-17.

Peck, J.E., 2010. Multivariate Analysis for Community Ecologists: Step-by-Step using PC-ORD. MjM Software Design, Gleneden Beach, Oregon.

Pimentel, D., Zuniga, R., Morrison, D., 2005. Update on the environmental and economic costs associated with alien-invasive species in the United States. Ecol. Econ. 52, 273-288.

Plut, K., Paul, J., Ciotir, C., Major, M., Freeland, J.R., 2011. Origin of non-native Phragmites australis in North America, a common wetland invader. Fundam. Appl. Limnol. 179, 121129.

Poole, A.F., Lowther, P., Gibbs, J.P., Reid, F.A., Melvin, S.M., 2009. Least Bittern (Ixobrychus 
exilis), in: Rodewald, P.G. (Ed.). The Birds of North America Online, Cornell Lab of Ornithology, Ithaca (https://birdsna.org/Species-Account/bna/species/leabit)

Price, A.L., Fant, J.B., Larkin, D.J., 2014. Ecology of native vs. introduced Phragmites australis (common reed) in chicago-area wetlands. Wetlands 34, 369-377.

Prince, H.H., Padding, P.I., Knapton, R.W., 1992. Waterfowl use of the Laurentian Great Lakes. J. Great Lakes Res. 18, 673-699.

Pulliam, H.R., 1988. Sources, sinks, and population regulation. Am. Nat. 132, 652-661.

R Core Team, 2016. R: A language and environment for statistical computing. R Found. Stat. Comput. Vienna, Austria.

Raichel, D.L., Able, K.W., Hartman, J.M., 2003. The influence of Phragmites (common reed) on the distribution, abundance, and potential prey of a resident marsh fish in the Hackensack Meadowlands, New Jersey. Estuaries 26, 511-521.

Reznicek, A.A., Catling, P.M., 1989. The flora of Long Point, Regional Municipality of Haldimond-Norfolk, Ontario. Michigan Bot. 28, 99-175.

Richardson, D.M., Allsopp, N., D’Antonio, C.M., Milton, S.J., Rejmánek, M., 2000a. Plant invasions -- the role of mutualisms. Biol. Rev. 75, 65-93.

Richardson, D.M., Pysek, P., Rejmanek, M., Barbour, M.G., Dane Panetta, F., West, C.J., 2000b. Naturalization and invasion of alien plants: Concepts and definitions. Divers. Distrib. 6, 93107.

Riffell, S.K., Keas, B.E., Burton, T.M., 2001. Area and habitat relationships of birds in Great Lakes coastal wet meadows. Wetlands 21, 492-507.

Robertson, B.A., Hutto, R.L., 2006. A framework for understanding ecological traps and an evaluation of existing evidence. Ecology 87, 1075-1085.

Rodewald, P., 2015. The Birds of North America Online, Cornell Laboratory of Ornithology. Ithaca, NY.

Rooth, J.E., Stevenson, J.C., Cornwell, J.C., 2003. Increased sediment accretion rates following invasion by Phragmites australis: The role of litter. Estuaries 26, 475-483. 
Rudrappa, T., Bonsall, J., Gallagher, J.L., Seliskar, D.M., Bais, H.P., 2007. Root-secreted allelochemical in the noxious weed Phragmites australis deploys a reactive oxygen species response and microtubule assembly disruption to execute rhizotoxicity. J. Chem. Ecol. 33, 1898-918.

Saltonstall, K., 2016. The naming of Phragmites haplotypes. Biol. Invasions 18, 2433-2441.

Saltonstall, K., 2003a. Genetic variation among North American populations of Phragmites australis: Implications for management. Estuaries 26, 444-451.

Saltonstall, K., 2003b. Microsatellite variation within and among North American lineages of Phragmites australis. Mol. Ecol. 12, 1689-1702.

Saltonstall, K., 2002. Cryptic invasion by a non-native genotype of the common reed, Phragmites australis, into North America. Proc. Natl. Acad. Sci. U. S. A. 99, 2445-9.

Saltonstall, K., Castillo, H.E., Blossey, B., 2014. Confirmed field hybridization of native and introduced Phragmites australis (Poaceae) in North America. Am. J. Bot. 101, 211-5.

Saltonstall, K., Lambert, A., Meyerson, L.A., 2010. Genetics and reproduction of common (Phragmites australis) and giant reed (Arundo donax). Invasive Plant Sci. Manag. 3, 495505.

Saltonstall, K., Lambert, A.M., Rice, N., 2016. What happens in Vegas, better stay in Vegas: Phragmites australis hybrids in the Las Vegas Wash. Biol. Invasions 18, 2463-2474.

Schummer, M.L., Palframan, J., McNaughton, E., Barney, T., Petrie, S.A., 2012. Comparisons of bird, aquatic macroinvertebrate, and plant communities among dredged ponds and natural wetland habitats at Long Point, Lake Erie, Ontario. Wetlands 32, 945-953.

Sciance, M.B., Patrick, C.J., Weller, D.E., Williams, M.N., McCormick, M.K., Hazelton, E.L.G., 2016. Local and regional disturbances associated with the invasion of Chesapeake Bay marshes by the common reed Phragmites australis. Biol. Invasions 18, 2661-2677.

Shay, J.M., Shay, C.T., 1986. Prairie marshes in western Canada, with specific reference to the ecology of five emergent macrophytes. Can. J. Bot. 64, 443-454.

Stabile, J., Lipus, D., Maceda, L., Maltz, M., Roy, N., Wirgin, I., 2016. Microsatellite DNA 
analysis of spatial and temporal population structuring of Phragmites australis along the Hudson River Estuary. Biol. Invasions 18, 2517-2529. doi:10.1007/s10530-016-1157-7

Tewksbury, L., Casagrande, R., Blossey, B., Häfliger, P., Schwarländer, M., 2002. Potential for biological control of Phragmites australis in North America. Biol. Control 23, 191-212.

Theoharides, K.A., Dukes, J.S., 2007. Plant invasion across space and time: factors affecting nonindigenous species success during four stage of invasion. New Phytol. 176, 256-273.

Tilman, D., May, R.., Lehman, C.., Nowak, M.., 1994. Habitat destruction and the extinction debt. Nature 371, 65-66.

Tougas-Tellier, M.A., Morin, J., Hatin, D., Lavoie, C., 2015. Freshwater wetlands: Fertile grounds for the invasive Phragmites australis in a climate change context. Ecol. Evol. 5, $3421-3435$.

Tozer, D.C., 2016. Marsh bird occupancy dynamics, trends, and conservation in the southern Great Lakes basin: 1996 to 2013. J. Great Lakes Res. 42, 136-145.

Trebitz, A.S., Taylor, D.., 2007. Exotic and invasive aquatic plants in Great Lakes coastal wetlands: Distribution and relation to watershed land use and plant richness and cover. J. Great Lakes Res. 33, 705-721.

Tulbure, M.., Johnston, C.A., Auger, D.L., 2007. Rapid invasion of a Great Lakes coastal wetland by non-native Phragmites australis and Typha. J. Great Lakes Res. 33, 269-279.

Tulbure, M.G., Johnston, C.A., 2010. Environmental conditions promoting non-native Phragmites australis expansion in Great Lakes coastal wetlands. Wetlands 30, 577-587.

Uddin, M.N., Robinson, R.W., Caridi, D., 2014. Phytotoxicity induced by Phragmites australis: an assessment of phenotypic and physiological parameters involved in germination process and growth of receptor plant. J. Plant Interact. 9, 338-353.

UNESCO, 2015. Long Point, United Nations Educational, Scientific, and Cultural Organization [WWW Document]. URL http://www.unesco.org/new/en/naturalsciences/environment/ecological-sciences/biosphere-reserves/europe-northamerica/canada/long-point) 
Vasquez, E.A., Glenn, E.P., Brown, J.J., Guntenspergen, G.R., Nelson, S.G., 2005. Salt tolerance underlies the cryptic invasion of North American salt marshes by an introduced haplotype of the common reed Phragmites australis (Poaceae). Mar. Ecol. Prog. Ser. 298, 1-8.

Venter, O., Brodeur, N.N., Nemiroff, L., Belland, B., Dolinsek, I.J., and Grant, J.W.A. 2006. Threats to endagered speices in Canada. BioScience 56, 903 - 910.

Vermeij, G.., 1996. An agenda for invasion biology. Biol. Conserv. 78, 3-9.

Vilà, M., Espinar, J.L., Hejda, M., Hulme, P.E., Jarošík, V., Maron, J.L., Pergl, J., Schaffner, U., Sun, Y., Pyšek, P., 2011. Ecological impacts of invasive alien plants: a meta-analysis of their effects on species, communities and ecosystems. Ecol. Lett. 14, 702-8.

Vretare, V., Weisner, S.E.B., Strand, J.A., Granéli, W., 2001. Phenotypic plasticity in Phragmites australis as a functional response to water depth. Aquat. Bot. 69, 127-145.

Voss, E.G., Reznicek, A.A. 2012. Field Manual of Michigan Flora. Chicago, Illinois, 990

Warren, R.S., Fell, P.E., Grimsby, J.L., Buck, E.L., Rilling, G.C., Fertike, R.A., 2001. Rates, patterns, and impacts of Phragmites expansion and effects of experimental Phragmites control on vegetation, macroinvertebrates, and fish within the tidelands of the lower Connecticut river. Estuaries 24, 90-107.

Warren, S.R., Fell, P.E., Grimsby, J.L., Buck, E.L., Rilling, G.C., Fertik, R.A., 2001. Rates, patterns, and impacts of Phragmites australis expansion and effects of experimental Phragmites control on vegetation, macroinvertebrates, and fish within tidelands of the Lower Connecticut River. Estuaries 24, 90-107.

WCSP, 2015. World Checklist of Selected Plant Families. Facilitated by the Royal Botanic Gardens, Kew. (http://apps.kew.org/wcsp)

Weidenhamer, J.D., Li, M., Allman, J., Bergosh, R.G., Posner, M., 2013. Evidence does not support a role for gallic acid in Phragmites australis invasion success. J. Chem. Ecol. 39, $323-32$.

Weinstein, M.P., Balletro, J.H., 1999. Does the common reed, Phragmites australis, affect essential fish habitat? Estuaries 22, 793-802. 
Weisner, S.E.B., Ekstam, B., 1993. Influence of germination time on juvenile performance of Phragmites australis on temporarily exposed bottoms - implications for the colonization of lake beds. Aquat. Bot. 45, 107-118.

Wells, A.W., Nieder, W.C., Swift, B.L., O’Connor, K.A., Weiss, C.A., 2008. Temporal changes in the breeding bird community at Four Hudson River tidal marshes. J. Coast. Res. 55, 221235.

Wersal, R.M., Madsen, J.D., Cheshier, J.C., 2013. Seasonal biomass and starch allocation of common reed (Phragmites australis) (Haplotype I) in Southern Alabama, USA. Invasive Plant Sci. Manag. 6, 140-146.

Whyte, R.S., Bocetti, C.I., Klarer, D.M., 2015. Bird assemblages in Phragmites dominated and non-Phragmites habitats in two Lake Erie coastal marshes. Nat. Areas J. 35, 235-245.

Whyte, R.S., Trexel-Kroll, D., Klarer, D.M., Shields, R., Francko, D. A., 2008. The invasion and spread of Phragmites australis during a period of low water in a Lake Erie coastal wetland. J. Coast. Res. 55, 111-120.

Wilcox, D.A., 2012. Response of wetland vegetation to the post-1986 decrease in Lake St. Clair water levels: Seed-bank emergence and beginnings of the Phragmites australis invasion. J. Great Lakes Res. 38, 270-277.

Wilcox, K.L., Petrie, S.A., Maynard, L.A., Meyer, S.W., 2003. Historical distribution and abundance of Phragmites australis at Long Point, Lake Erie, Ontario. J. Great Lakes Res. 29, 664-680.

Windham, L., 2001. Comparison of biomass production and decomposition between Phragmites australis (common reed) and Spartina patens (Salt Hay grass) in brackish tidal marshes of New Jersey, USA. Wetlands 21, 179-188.

Windham, L., Lathrop, R.G., 1999. Effect of Phragmites australis (common reed) invasion on aboveground biomass and soil properties in brackish tidal marsh of Mullica River, New Jersey. Estuaries 22, 927-935.

Wolfe, L.M., 2002. Why alien invaders succeed: Support for the escape-from-enemy hypothesis. Am. Nat. 160, 705-11. 
Zedler, J.B., Kercher, S., 2004. Causes and consequences of invasive plants in wetlands: Opportunities, opportunists, and outcomes. CRC. Crit. Rev. Plant Sci. 23, 431-452.

Zimmerman, G.., Goetz, H., Meilke, P.., Meilke, P.W.J., 1985. Use of an improvised statistical method for group comparisons to study effects of prairie fire. Ecology 66, 606-611. 


\section{Appendices}

Appendix 1: Photos illustrating the vegetative reproductive characteristics of Phragmites australis: A) P. australis emergence from a rhizome; B) horizontal rhizome; C) stolons expanding laterally from an established stand; D) a knocked-over stem producing shoots
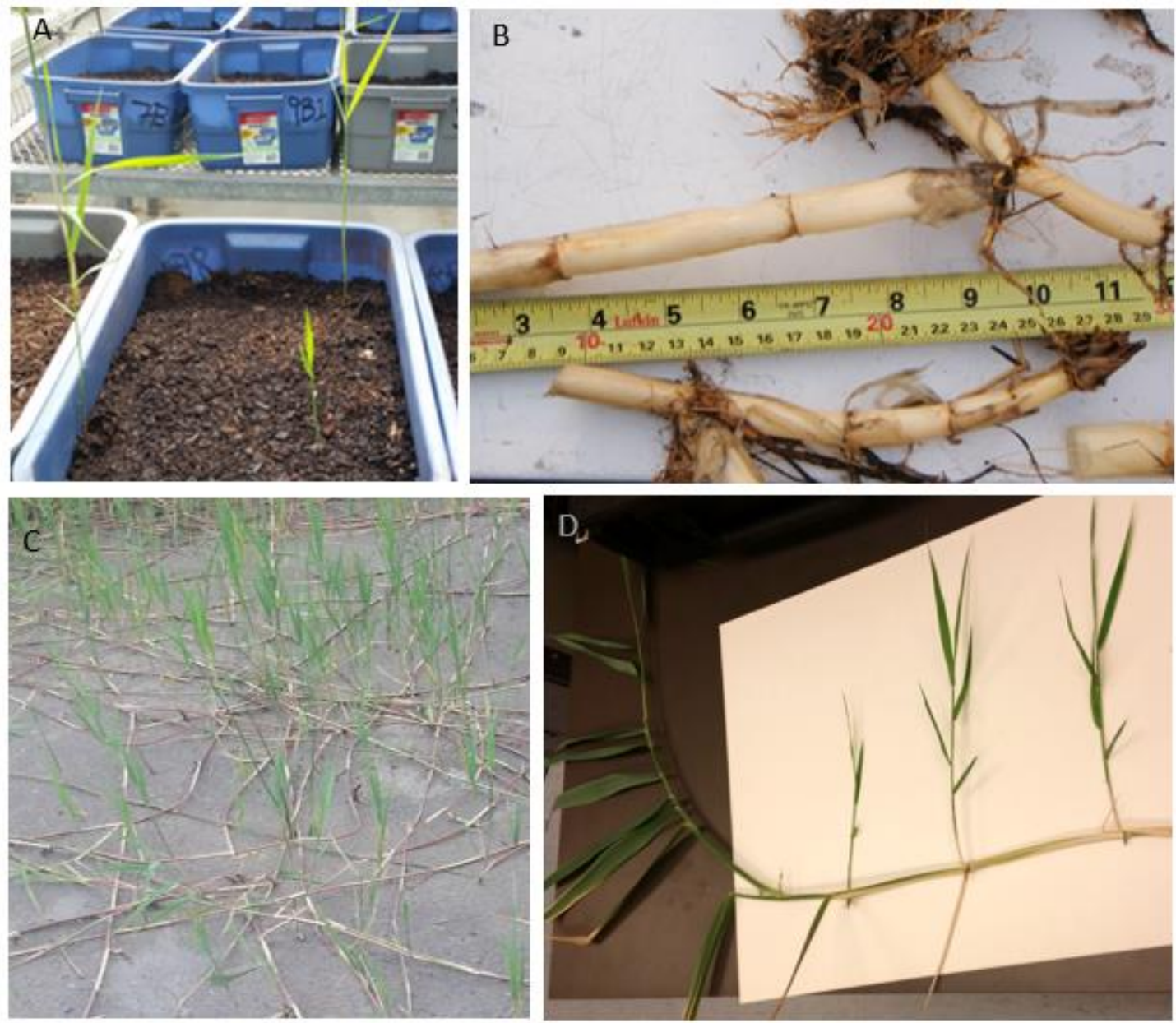
Appendix 2: Extent of Phragmites australis land cover in Crown Marsh and Long Point

Provincial Park, Long Point, 2015. Imaging courtesy Ducks Unlimited Canada.

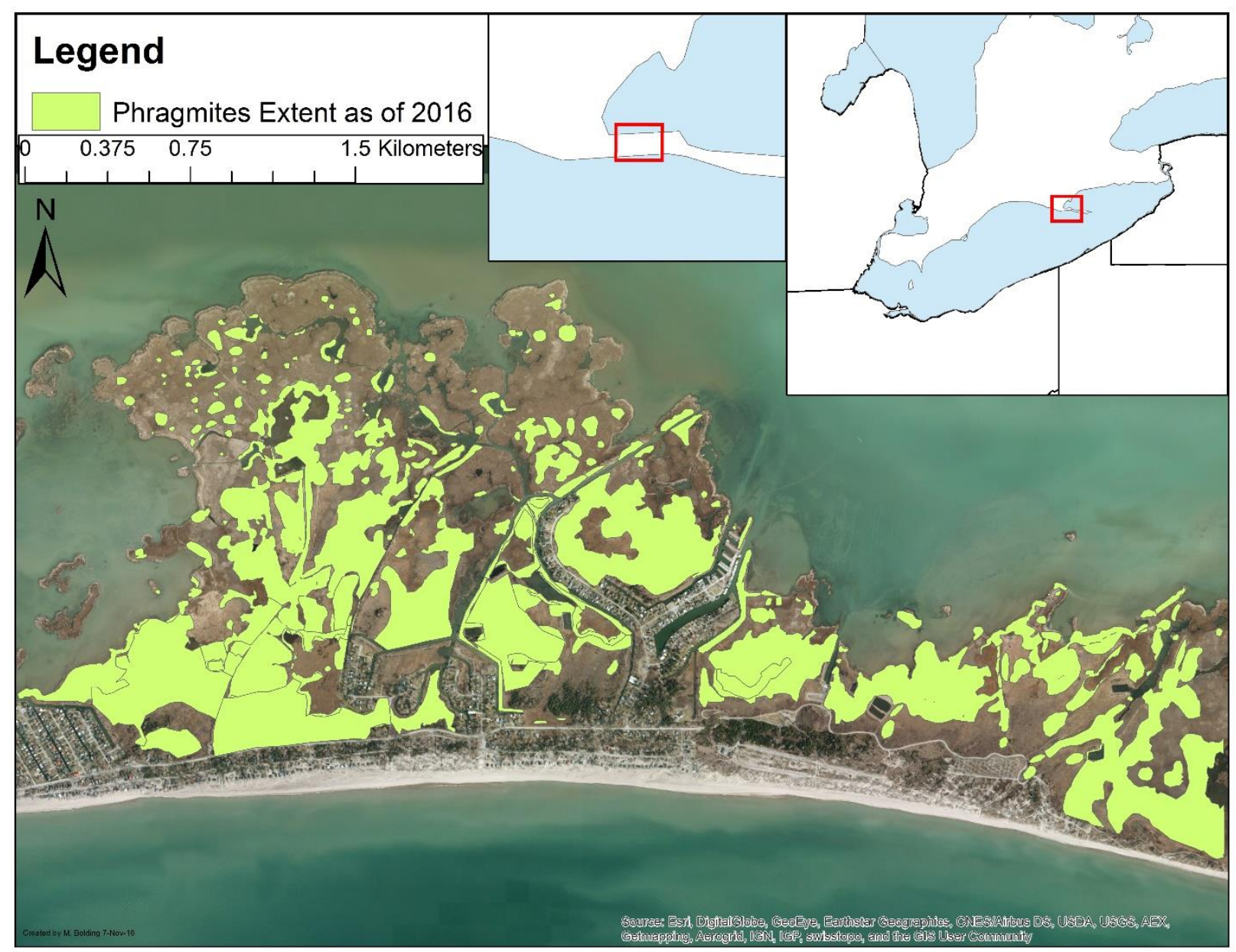


Appendix 3: Photos illustrating the four vegetation types: a) Phragmitess australis, b) cattail marsh, c) meadow marsh, and d) open-water.
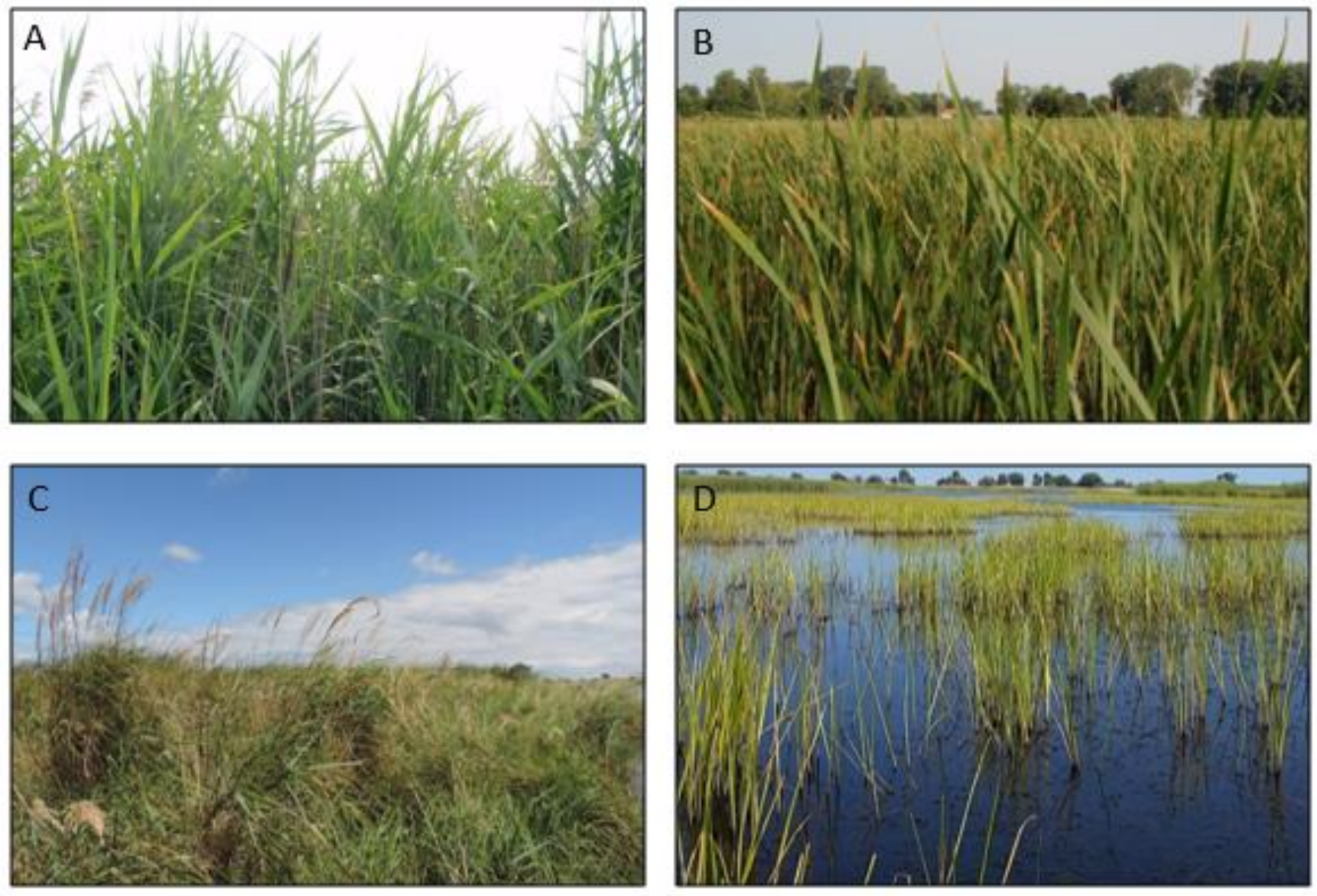
Appendix 4: Table 1. All plant and charophyte species identified in August 2015 vegetation surveys at bird point count locations in Long Point, ON using Michigan Flora (Voss and Reznicek, 2012), and verified with the integrated taxonomic information system

\begin{tabular}{|c|c|c|c|}
\hline Cattail marsh & Meadow marsh & P. australis & Open-water \\
\hline Agrostis stolonifera & Asclepias syriaca & $\begin{array}{l}\text { Calamagrostis } \\
\text { canadensis }\end{array}$ & $\begin{array}{l}\text { Ceratophyllum } \\
\text { demersum }\end{array}$ \\
\hline $\begin{array}{l}\text { Calamagrostis } \\
\text { canadensis }\end{array}$ & Aster spp. & Calystegia sepium & Chara spp. \\
\hline $\begin{array}{l}\text { Campanula } \\
\text { aparinoides }\end{array}$ & $\begin{array}{l}\text { Calamagrostis } \\
\text { canadensis }\end{array}$ & Campanula aparinoides & Elodea canadensis \\
\hline Carex aquatilis & Calystegia sepium & Carex aquatilis & Myrophyllum spp. \\
\hline Carex comosa & $\begin{array}{l}\text { Campanula } \\
\text { aparinoides }\end{array}$ & Carex comosa & Nitella spp. \\
\hline Decodon verticillatus & Carex aquatilis & Carex lacustris & Nuphar lutea \\
\hline Equisetum fluviatile & Carex buxbaumii & Carex lasiocarpa & Nymphaea odorata \\
\hline $\begin{array}{l}\text { Hydrocharis morsus- } \\
\text { ranae }\end{array}$ & Carex lasiocarpa & Carex spp. & Pontederia cordata \\
\hline Leersia oryzoides & Carex prasina & Cirsium muticum & Potamogeton spp. \\
\hline Lemna minor & Carex spp. & Cladium mariscus & $\begin{array}{l}\text { Potamogeton } \\
\text { illinoensis }\end{array}$ \\
\hline $\begin{array}{l}\text { Lysimachia } \\
\text { thyrsiflora }\end{array}$ & Chara spp. & Cornus stolonifera & $\begin{array}{l}\text { Potamogeton } \\
\text { pectinatus }\end{array}$ \\
\hline Mentha spp. & Cirsium muticum & Decodon verticillatus & Sagittaria latifolia \\
\hline Nuphar lutea & Cladium mariscus & Helenium autumnale & Sagittaria rigida \\
\hline $\begin{array}{l}\text { Phragmites australis } \\
\text { (M) }\end{array}$ & Cornus amomum & $\begin{array}{l}\text { Hydrocharis morsus- } \\
\text { ranae }\end{array}$ & $\begin{array}{l}\text { Schoenoplectus } \\
\text { acutus var. acutus }\end{array}$ \\
\hline $\begin{array}{l}\text { Phragmites australis } \\
\text { subsp. americanus }\end{array}$ & Cornus stolonifera & Hypericum kalmianum & $\begin{array}{l}\text { Spirodela } \\
\text { polyrrhiza }\end{array}$ \\
\hline Persicaria amphibia & Decodon verticillatus & Impatiens capensis & Typha x glauca \\
\hline Sagittaria latifolia & Eleocharis smallii & Juncus balticus & Utricularia spp. \\
\hline Sagittaria rigida & Eleocharis spp. & Juncus brevicaudatus & Utricularia minor \\
\hline $\begin{array}{l}\text { Schoenoplectus } \\
\text { acutus var. acutus }\end{array}$ & $\begin{array}{l}\text { Epilobium } \\
\text { leptophyllum }\end{array}$ & Lemna minor & $\begin{array}{l}\text { Utricularia } \\
\text { vulgaris }\end{array}$ \\
\hline $\begin{array}{l}\text { Bolboschoenus } \\
\text { fluviatilis }\end{array}$ & Epilobium palustre & Lycopus spp. & Zizania palustris \\
\hline $\begin{array}{l}\text { Schoenoplectus } \\
\text { pungens var. pungens }\end{array}$ & Helenium autumnale & Lysimachia thyrsiflora & \\
\hline Spirodela polyrrhiza & $\begin{array}{l}\text { Hydrocharis morsus- } \\
\text { ranae }\end{array}$ & Lythrum salicaria & \\
\hline Thelypteris palustris & $\begin{array}{l}\text { Hypericum } \\
\text { kalmianum }\end{array}$ & Phragmites australis (M) & \\
\hline
\end{tabular}




\begin{tabular}{|c|c|c|c|}
\hline Cattail marsh & Meadow marsh & P. australis & Open-water \\
\hline Triadenum fraseri & Juncus brevicaudatus & Persicaria amphibia & \\
\hline Typha angustifolia & Juncus arcticus & $\begin{array}{l}\text { Schoenoplectus pungens } \\
\text { var. pungens }\end{array}$ & \\
\hline Typha latifolia & Juncus tenuis & Solidago ohioensis & \\
\hline \multirow[t]{29}{*}{ Typha $\mathbf{x}$ glauca } & Lathyrus spp. & Solidago uliginosa & \\
\hline & Lathyrus palustris & Spirodela polyrrhiza & \\
\hline & Leersia oryzoides & Stachys palustris & \\
\hline & Lemna minor & Thelypteris palustris & \\
\hline & Lycopus uniflorus & Triadenum fraseri & \\
\hline & $\begin{array}{l}\text { Lysimachia } \\
\text { thyrsiflora }\end{array}$ & Typha angustifolia & \\
\hline & Lysimachia spp. & Typha x glauca & \\
\hline & Lythrum salicaria & Utricularia intermedia & \\
\hline & Mentha spp. & & \\
\hline & Nitella spp. & & \\
\hline & $\begin{array}{l}\text { Phragmites australis } \\
\text { (M) }\end{array}$ & & \\
\hline & Persicaria amphibia & & \\
\hline & Potentilla anserina & & \\
\hline & ssp. anserina & & \\
\hline & Rosa acicularis & & \\
\hline & Sagittaria latifolia & & \\
\hline & Schoenoplectus & & \\
\hline & pungens var. pungens & & \\
\hline & Solidago ohioensis & & \\
\hline & Solidago uliginosa & & \\
\hline & Sorghastrum nutans & & \\
\hline & Spirodela polyrrhiza & & \\
\hline & Stachys palustris & & \\
\hline & Symphyotrichum & & \\
\hline & puniceum & & \\
\hline & Thelypteris palustris & & \\
\hline & Triadenum fraseri & & \\
\hline & Typha latifolia & & \\
\hline & Typha x glauca & & \\
\hline
\end{tabular}


Appendix 5: All birds, and their corresponding functional traits, observed during the 2015 Long

Point, ON field season. Marsh-nesting species are indicated with an asterisks $\left(^{*}\right)$, and are further divided into marsh-nesting species of concern $\left({ }^{ \pm}\right)$

\begin{tabular}{|c|c|c|c|c|}
\hline Common name & Scientific name & Diet & $\begin{array}{l}\text { Foraging } \\
\text { behavior }\end{array}$ & $\begin{array}{l}\text { Nesting } \\
\text { preference }\end{array}$ \\
\hline American Bittern $*^{ \pm}$ & Botaurus lentiginosus & Fish & Stalking & Ground \\
\hline Swamp Sparrow* & Melospiza georgiana & Insect & Ground forage & Shrub \\
\hline Marsh Wren* & Cistothorus palustris & Insect & Ground forage & Shrub \\
\hline Sora* $*^{ \pm}$ & Porzana carolina & Seed & Ground forage & Floating \\
\hline Least Bittern $*^{ \pm}$ & Ixobrychus exilis & Fish & Stalking & Ground \\
\hline Great Blue Heron & Ardea herodias & Fish & Stalking & Tree \\
\hline Least Sandpiper & Calidris minutilla & Insect & Probing & Ground \\
\hline Virginia Rail ${ }^{* \pm}$ & Rallus limicola & Insect & Probing & Ground \\
\hline Common Yellowthroat* & Geothlypis trichas & Insect & Foliage glean & Shrub \\
\hline Red-winged Blackbird & Agelaius phoeniceus & Insect & Ground forage & Shrub \\
\hline Yellow Warbler & Dendroica petechia & Insect & Foliage glean & Shrub \\
\hline Gray Catbird & Dumetella carolinensis & Insect & Ground forage & Shrub \\
\hline Song Sparrow & Melospiza melodia & Insect & Ground forage & Shrub \\
\hline Willow Flycatcher & Empidonax traillii & Insect & Flycatcher & Shrub \\
\hline Tree Swallow & Tachycineta bicolor & Insect & Aerial forage & Cavity \\
\hline Barn Swallow & Hirundo rustica & Insect & Aerial forage & Build \\
\hline Bank Swallow & Riparia riparia & Insect & Aerial forage & Burrow \\
\hline Eastern Kingbird & Tyrannus tyrannus & Insect & Flycatcher & Tree \\
\hline Purple Martin & Progne subis & Insect & Aerial forage & Cavity \\
\hline Chestnut-sided Warbler & Dendroica pensylvania & Insect & Foliage glean & Shrub \\
\hline Downy Woodpecker & Picoides pubescens & Insect & Bark forage & Cavity \\
\hline Common Grackle & Quiscalus quiscula & Omnivore & Ground forage & Tree \\
\hline Canada Goose* & Branta canadensis & Seed & Ground forage & Ground \\
\hline Cliff Swallow & Petrochelidon pyrrhonota & Insect & Aerial forage & Cliff \\
\hline Common Tern & Sterna hirundo & Fish & Aerial dive & Ground \\
\hline Mute Swan & Cygnus olor & Plant & Dabbler & Ground \\
\hline Sandhill Crane* & Grus canadensis & Omnivore & Probe & Ground \\
\hline Wood Duck* & Aix sponsa & Insect & Dabbler & Cavity \\
\hline Blue-winged Teal* & Chlidonias niger & Seed & Dabbler & Ground \\
\hline Mallard* & Anas platyrhynchos & Seed & Dabbler & Ground \\
\hline Caspian Tern & Hydroprogne caspia & Fish & Aerial dive & Ground \\
\hline American Robin & Turdus migratorius & Insect & Ground forage & Tree \\
\hline
\end{tabular}


Appendix 6. Sum of all bird sightings by vegetation type from May - August 2015 in Long

Point, ON. Marsh-nesting species are indicated with an asterisks (*), and are further divided into marsh-nesting species of concern $\left(^{ \pm}\right)$

\begin{tabular}{|c|c|c|c|c|c|}
\hline Common name & Scientific name & P. australis & $\begin{array}{l}\text { Meadow } \\
\text { marsh }\end{array}$ & $\begin{array}{l}\text { Cattail } \\
\text { marsh }\end{array}$ & Open-water \\
\hline American Bittern* ${ }^{ \pm}$ & Botaurus lentiginosus & 0 & 0 & 1 & 1 \\
\hline Swamp Sparrow* & Melospiza georgiana & 37 & 45 & 53 & 6 \\
\hline Marsh Wren* & Cistothorus palustris & 31 & 25 & 42 & 12 \\
\hline Sora $* \pm$ & Porzana carolina & 0 & 2 & 0 & 0 \\
\hline Least Bittern ${ }^{* \pm}$ & Ixobrychus exilis & 0 & 1 & 1 & 2 \\
\hline Great Blue Heron & Ardea herodias & 0 & 0 & 2 & 3 \\
\hline Least Sandpiper & Calidris minutilla & 0 & 0 & 0 & 1 \\
\hline Virginia Rail*士 & Rallus limicola & 0 & 2 & 3 & 1 \\
\hline $\begin{array}{l}\text { Common } \\
\text { Yellowthroat* }\end{array}$ & Geothlypis trichas & 37 & 35 & 41 & 6 \\
\hline Red-winged Blackbird & Agelaius phoeniceus & 64 & 95 & 115 & 34 \\
\hline Yellow Warbler & Dendroica petechia & 12 & 4 & 2 & 1 \\
\hline Gray Catbird & Dumetella carolinensis & 3 & 0 & 0 & 0 \\
\hline Song Sparrow & Melospiza melodia & 3 & 11 & 0 & 0 \\
\hline Willow Flycatcher & Empidonax traillii & 1 & 1 & 1 & 0 \\
\hline Tree Swallow & Tachycineta bicolor & 1 & 14 & 3 & 13 \\
\hline Barn Swallow & Hirundo rustica & 2 & 3 & 0 & 3 \\
\hline Bank Swallow & Riparia riparia & 0 & 2 & 2 & 8 \\
\hline Eastern Kingbird & Tyrannus tyrannus & 2 & 5 & 4 & 0 \\
\hline Purple Martin & Progne subis & 0 & 2 & 0 & 0 \\
\hline $\begin{array}{l}\text { Chestnut-sided } \\
\text { Warbler }\end{array}$ & Dendroica pensylvania & 0 & 1 & 0 & 0 \\
\hline Downy Woodpecker & Picoides pubescens & 1 & 0 & 0 & 0 \\
\hline Common Grackle & Quiscalus quiscula & 0 & 2 & 1 & 0 \\
\hline Canada Goose* & Branta canadensis & 0 & 0 & 0 & 5 \\
\hline Cliff Swallow & Petrochelidon pyrrhonota & 0 & 6 & 1 & 3 \\
\hline Common Tern & Sterna hirundo & 0 & 0 & 0 & 2 \\
\hline Mute Swan & Cygnus olor & 0 & 0 & 0 & 1 \\
\hline Sandhill Crane* & Grus canadensis & 0 & 0 & 2 & 1 \\
\hline Wood Duck* & Aix sponsa & 0 & 0 & 0 & 17 \\
\hline Blue-winged Teal* & Chlidonias niger & 0 & 0 & 0 & 2 \\
\hline Mallard* & Anas platyrhynchos & 0 & 0 & 0 & 2 \\
\hline Caspian Tern & Hydroprogne caspia & 0 & 0 & 0 & 2 \\
\hline American Robin & Turdus migratorius & 0 & 1 & 0 & 1 \\
\hline
\end{tabular}


Appendix 7: 2D NMS ordination solution of Bray-Curtis dissimilarity matrix calculated using bird species abundances with bird species vectors overlaid (final stress $=22.98$ ). In this joint plot, only species whose abundance was reasonably correlated with at least one ordination axis are depicted as vectors. Symbology of points reflects the three vegetation types considered: Phragmites australis, cattail marsh, meadow marsh.

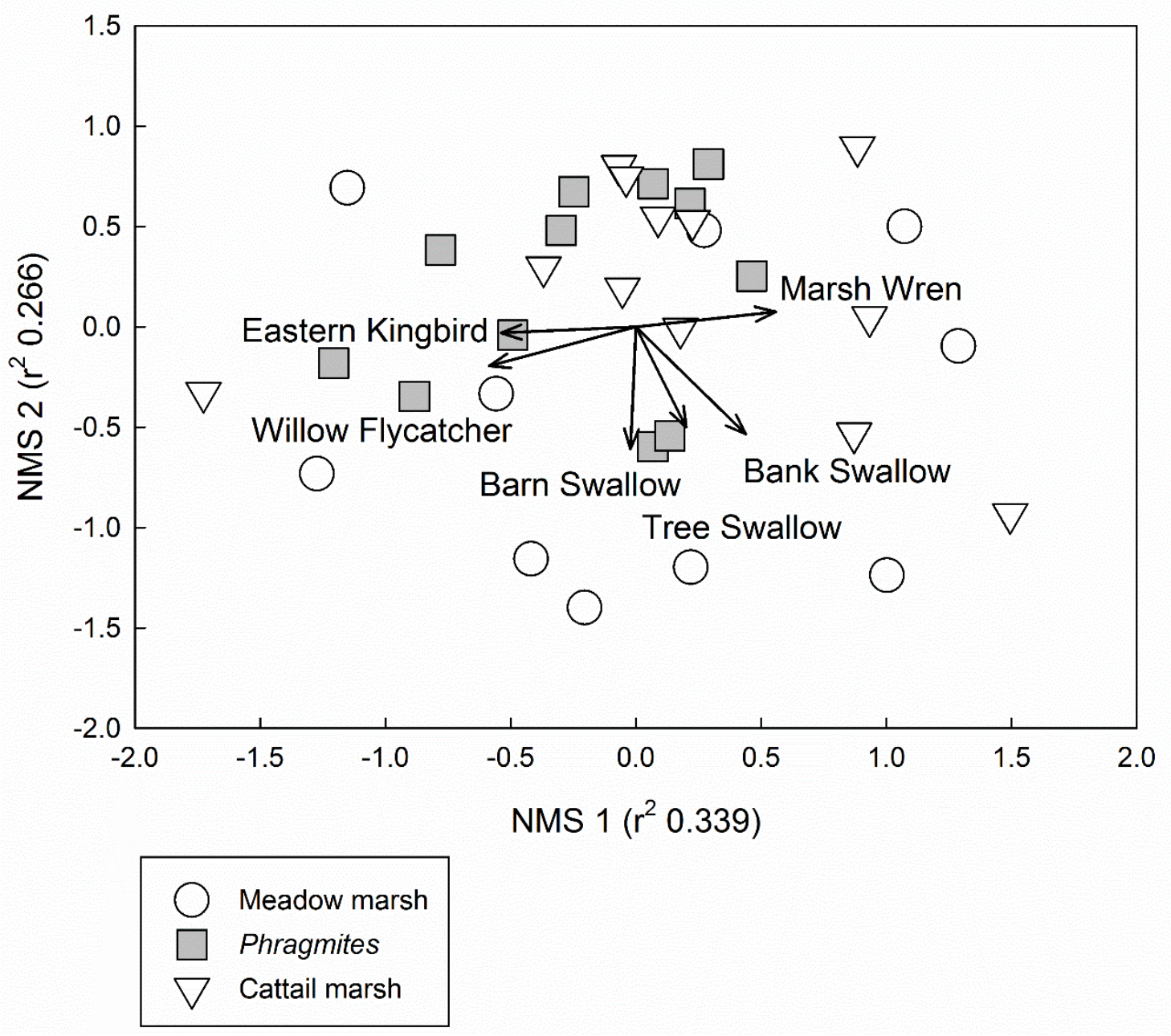


Appendix 8. GPS coordinates and vegetation covariates for all 48 point count locations in Big Creek National Wildlife Area (BC), Long Point Provincial Park (LP), and Crown Marsh (CM). All vegetation covariates are based on the average of three quadrats per site. GPS coordinates are in UTM zone 17.

\begin{tabular}{|c|c|c|c|c|c|c|}
\hline Site ID & Easting & Northing & $\begin{array}{l}\text { Vegetation } \\
\text { type }\end{array}$ & $\begin{array}{l}\text { Patch } \\
\text { location }\end{array}$ & $\begin{array}{l}\text { Total vegetation } \\
\text { cover }(\%)+/- \\
\text { SD }\end{array}$ & $\begin{array}{l}\text { Dominant species } \\
(\text { relative cover \%) +/- } \\
\text { SD }\end{array}$ \\
\hline BC ME1 & 544824.00 & 4715225.00 & Meadow & Edge & $66(+/-30)$ & $\begin{array}{l}\text { Calamagrostis } \\
\text { canadensis } \\
80(+/-17)\end{array}$ \\
\hline BC ME2 & 544655.00 & 4714303.00 & Meadow & Edge & $99(+/-1)$ & $\begin{array}{l}\text { Calamagrostis } \\
\text { canadensis } \\
77(+/-5)\end{array}$ \\
\hline CM 9 & 547137.85 & 4714613.72 & Meadow & Edge & $20(+/-11)$ & $\begin{array}{l}\text { Cladium mariscus } \\
35(+/-16)\end{array}$ \\
\hline CM 10 & 546955.29 & 4714643.33 & Meadow & Edge & $35(+/-4)$ & $\begin{array}{l}\text { Calamagrostis } \\
\text { canadensis } \\
24(+/-6)\end{array}$ \\
\hline LP 12 & 551332.86 & 4714520.07 & Meadow & Edge & $43(+/-19)$ & $\begin{array}{l}\text { Calamagrostis } \\
\text { canadensis } \\
31(+/-26)\end{array}$ \\
\hline LP 8R & 551023.00 & 4714879.00 & Meadow & Edge & $82(+/-19)$ & $\begin{array}{l}\text { Calamagrostis } \\
\text { canadensis } \\
72(+/-16)\end{array}$ \\
\hline BC MI1 & 545148.00 & 4715205.00 & Meadow & Interior & $87(+/-13)$ & $\begin{array}{l}\text { Calamagrostis } \\
\text { canadensis } \\
95(+/-7)\end{array}$ \\
\hline BC MI2 & 544956.00 & 4714585.00 & Meadow & Interior & $76(+/-19)$ & $\begin{array}{l}\text { Calamagrostis } \\
\text { canadensis } \\
88(+/-5)\end{array}$ \\
\hline
\end{tabular}




\begin{tabular}{|c|c|c|c|c|c|c|}
\hline Site ID & Easting & Northing & $\begin{array}{l}\text { Vegetation } \\
\text { type }\end{array}$ & $\begin{array}{l}\text { Patch } \\
\text { location }\end{array}$ & $\begin{array}{l}\text { Total vegetation } \\
\text { cover }(\%)+/- \\
\text { SD }\end{array}$ & $\begin{array}{l}\text { Dominant species } \\
(\text { relative cover \%) +/- } \\
\text { SD }\end{array}$ \\
\hline $\mathrm{BC} \mathrm{MI3}$ & 544483.00 & 4714504.00 & Meadow & Interior & $56(+/-19)$ & $\begin{array}{l}\text { Calamagrostis } \\
\text { canadensis } \\
74(+/-8)\end{array}$ \\
\hline LP 5 & 550603.43 & 4714514.71 & Meadow & Interior & $33(+/-4)$ & $\begin{array}{l}\text { Calamagrostis } \\
\text { canadensis } \\
20(+/-3)\end{array}$ \\
\hline LP 6 & 551059.78 & 4714456.36 & Meadow & Interior & $50(+/-6)$ & $\begin{array}{l}\text { Solidago ohioensis } \\
27(+/-7)\end{array}$ \\
\hline CM MI1 & 549064.00 & 4714775.00 & Meadow & Interior & $18(+/-5)$ & $\begin{array}{l}\text { Calamagrostis } \\
\text { canadensis } \\
18(+/-31)\end{array}$ \\
\hline $\mathrm{CM} 2$ & 547412.43 & 4714461.36 & Phragmites & Edge & $20(+/-3)$ & $\begin{array}{l}\text { Phragmites australis } \\
34(+/-26)\end{array}$ \\
\hline LP 1 & 550352.03 & 4714605.43 & Phragmites & Edge & $56(+/-10)$ & $\begin{array}{l}\text { Phragmites australis } \\
87(+/-15)\end{array}$ \\
\hline LP 9 & 551334.22 & 4714335.00 & Phragmites & Edge & $79(+/-24)$ & $\begin{array}{l}\text { Phragmites australis } \\
18(+/-14)\end{array}$ \\
\hline BC PE1 & 544405.00 & 4714259.00 & Phragmites & Edge & $85(+/-11)$ & $\begin{array}{l}\text { Phragmites australis } \\
74(+/-35)\end{array}$ \\
\hline BC PE2 & 544211.00 & 4714689.00 & Phragmites & Edge & $71(+/-17)$ & $\begin{array}{l}\text { Phragmites australis } \\
87(+/-20)\end{array}$ \\
\hline CM 19 & 547725.00 & 4715388.00 & Phragmites & Edge & $47(+/-7)$ & $\begin{array}{l}\text { Phragmites australis } \\
23(+/-6)\end{array}$ \\
\hline CM 6 & 547661.69 & 4714678.99 & Phragmites & Interior & $63(+/-9)$ & $\begin{array}{l}\text { Phragmites australis } \\
97(+/-3)\end{array}$ \\
\hline LP 19 & 550851.46 & 4714886.68 & Phragmites & Interior & $43(+/-9)$ & $\begin{array}{l}\text { Phragmites australis } \\
68(+/-27)\end{array}$ \\
\hline LP $12 \mathrm{R}$ & 549727.37 & 4714787.13 & Phragmites & Interior & $74(+/-21)$ & $\begin{array}{l}\text { Phragmites australis } \\
95(+/-6)\end{array}$ \\
\hline
\end{tabular}




\begin{tabular}{|c|c|c|c|c|c|c|}
\hline Site ID & Easting & Northing & $\begin{array}{l}\text { Vegetation } \\
\text { type }\end{array}$ & $\begin{array}{l}\text { Patch } \\
\text { location }\end{array}$ & $\begin{array}{l}\text { Total vegetation } \\
\text { cover }(\%)+/- \\
\text { SD }\end{array}$ & $\begin{array}{l}\text { Dominant species } \\
(\text { relative cover \%) +/- } \\
\text { SD }\end{array}$ \\
\hline LP 16R & 549880.73 & 4714993.66 & Phragmites & Interior & $66(+/-14)$ & $\begin{array}{l}\text { Phragmites australis } \\
99(+/-2)\end{array}$ \\
\hline BC PI1 & 543909.00 & 4714019.00 & Phragmites & Interior & $72(+/-13)$ & $\begin{array}{l}\text { Phragmites australis } \\
83(+/-24)\end{array}$ \\
\hline BC PI2 & 543954.00 & 4715651.00 & Phragmites & Interior & $94(+/-8)$ & $\begin{array}{l}\text { Phragmites australis } \\
100(+/-0.02)\end{array}$ \\
\hline BC TE1 & 545194.00 & 4715003.00 & Cattail & Edge & $75(+/-7)$ & $\begin{array}{l}\text { Typha spp. } \\
21(+/-2)\end{array}$ \\
\hline BC TE2 & 544595.00 & 4715119.00 & Cattail & Edge & $59(+/-20)$ & $\begin{array}{l}\text { Typha spp. } \\
84(+/-9)\end{array}$ \\
\hline LP 10 & 551404.21 & 4714119.59 & Cattail & Edge & $45(+/-12)$ & $\begin{array}{l}\text { Typha spp. } \\
55(+/-26)\end{array}$ \\
\hline LP 15 & 551170.80 & 4714858.18 & Cattail & Edge & $42(+/-4)$ & $\begin{array}{l}\text { Typha spp. } \\
63(+/-21)\end{array}$ \\
\hline LP 6R & 551443.00 & 4714845.00 & Cattail & Edge & $40(+/-14)$ & $\begin{array}{l}\text { Typha spp. } \\
93(+/-9)\end{array}$ \\
\hline BC TI1 & 544173.00 & 4715379.00 & Cattail & Interior & $17(+/-3)$ & $\begin{array}{l}\text { Typha spp. } \\
88(+/-12)\end{array}$ \\
\hline BC TI2 & 544060.00 & 4715894.00 & Cattail & Interior & $48(+/-11)$ & $\begin{array}{l}\text { Typha spp. } \\
95(+/-8)\end{array}$ \\
\hline $\mathrm{CM} 4 \mathrm{R}$ & 548166.62 & 4715395.77 & Cattail & Interior & $31(+/-6)$ & $\begin{array}{l}\text { Typha spp. } \\
88(+/-8)\end{array}$ \\
\hline CM 5R & 548029.83 & 4715562.28 & Cattail & Interior & $33(+/-0)$ & $\begin{array}{l}\text { Typha spp. } \\
100(+/-0)\end{array}$ \\
\hline LP 10R & 549788.01 & 4714581.35 & Cattail & Edge & $52(+/-3)$ & $\begin{array}{l}\text { Typha spp. } \\
97(+/-5)\end{array}$ \\
\hline LP 5R & 551696.00 & 4714961.00 & Cattail & Interior & $33(+/-8)$ & $\begin{array}{l}\text { Typha spp. } \\
94(+/-11)\end{array}$ \\
\hline
\end{tabular}




\begin{tabular}{|c|c|c|c|c|c|c|}
\hline Site ID & Easting & Northing & $\begin{array}{l}\text { Vegetation } \\
\text { type }\end{array}$ & $\begin{array}{l}\text { Patch } \\
\text { location }\end{array}$ & $\begin{array}{l}\text { Total vegetation } \\
\text { cover }(\%)+/- \\
\text { SD } \\
\end{array}$ & $\begin{array}{l}\text { Dominant species } \\
(\text { relative cover \%) +/- } \\
\text { SD }\end{array}$ \\
\hline LP 7R & 551206.69 & 4715052.17 & Cattail & Interior & $78(+/-24)$ & $\begin{array}{l}\text { Typha spp. } \\
44(+/-32)\end{array}$ \\
\hline BC OW1 & 544688.00 & 4716753.00 & $\begin{array}{l}\text { Open- } \\
\text { water }\end{array}$ & N/A & $33(+/-58)$ & $\begin{array}{l}\text { Typha spp. } \\
28(+/-49)\end{array}$ \\
\hline BC OW2 & 544572.00 & 4716439.00 & $\begin{array}{l}\text { Open- } \\
\text { water }\end{array}$ & N/A & $2(+/-3)$ & $\begin{array}{l}\text { Sagittaria rigida } \\
33(+/-58)\end{array}$ \\
\hline BC OW3 & 545080.00 & 4714799.00 & $\begin{array}{l}\text { Open- } \\
\text { water }\end{array}$ & N/A & $63(+/-26)$ & $\begin{array}{l}\text { Chara spp. } \\
54(+/-47)\end{array}$ \\
\hline BC OW4 & 544733.00 & 4714766.00 & $\begin{array}{l}\text { Open- } \\
\text { water }\end{array}$ & N/A & $85(+/-27)$ & $\begin{array}{l}\text { Nuphar lutea } \\
31(+/-54)\end{array}$ \\
\hline BC OW5 & 543997.00 & 4714577.00 & $\begin{array}{l}\text { Open- } \\
\text { water }\end{array}$ & N/A & $40(+/-16)$ & $\begin{array}{l}\text { Nuphar lutea } \\
78(+/-15)\end{array}$ \\
\hline BC OW6 & 545842.00 & 4714891.00 & $\begin{array}{l}\text { Open- } \\
\text { water }\end{array}$ & N/A & $98(+/-0.8)$ & $\begin{array}{l}\text { Nymphaea odorata } \\
78(+/-10)\end{array}$ \\
\hline BC OW7 & 544243.00 & 4715985.00 & $\begin{array}{l}\text { Open- } \\
\text { water }\end{array}$ & N/A & $100(+/-0)$ & $\begin{array}{l}\text { Potamogeton spp. } \\
33(+/-58)\end{array}$ \\
\hline BC OW8 & 545285.00 & 4714682.00 & $\begin{array}{l}\text { Open- } \\
\text { water }\end{array}$ & N/A & $19(+/-14)$ & $\begin{array}{l}\text { Nuphar lutea } \\
58(+/-50)\end{array}$ \\
\hline CM OW1 & 548937.00 & 4715056.00 & $\begin{array}{l}\text { Open- } \\
\text { water }\end{array}$ & N/A & $88(+/-6)$ & $\begin{array}{l}\text { Chara spp. } \\
51(+/-31)\end{array}$ \\
\hline CM OW2 & 547562.00 & 4714960.00 & $\begin{array}{l}\text { Open- } \\
\text { water }\end{array}$ & N/A & $100(+/-8)$ & $\begin{array}{l}\text { Utricularia vulgaris } \\
56(+/-49)\end{array}$ \\
\hline LP OW1 & 551539.00 & 4714636.00 & $\begin{array}{l}\text { Open- } \\
\text { water }\end{array}$ & N/A & $77(+/-21)$ & $\begin{array}{l}\text { Nuphar lutea } \\
43(+/-36)\end{array}$ \\
\hline LP OW2 & 551144.00 & 4714737.00 & $\begin{array}{l}\text { Open- } \\
\text { water }\end{array}$ & N/A & $67(+/-58)$ & $\begin{array}{l}\text { Chara spp. } \\
67(+/-58)\end{array}$ \\
\hline
\end{tabular}

